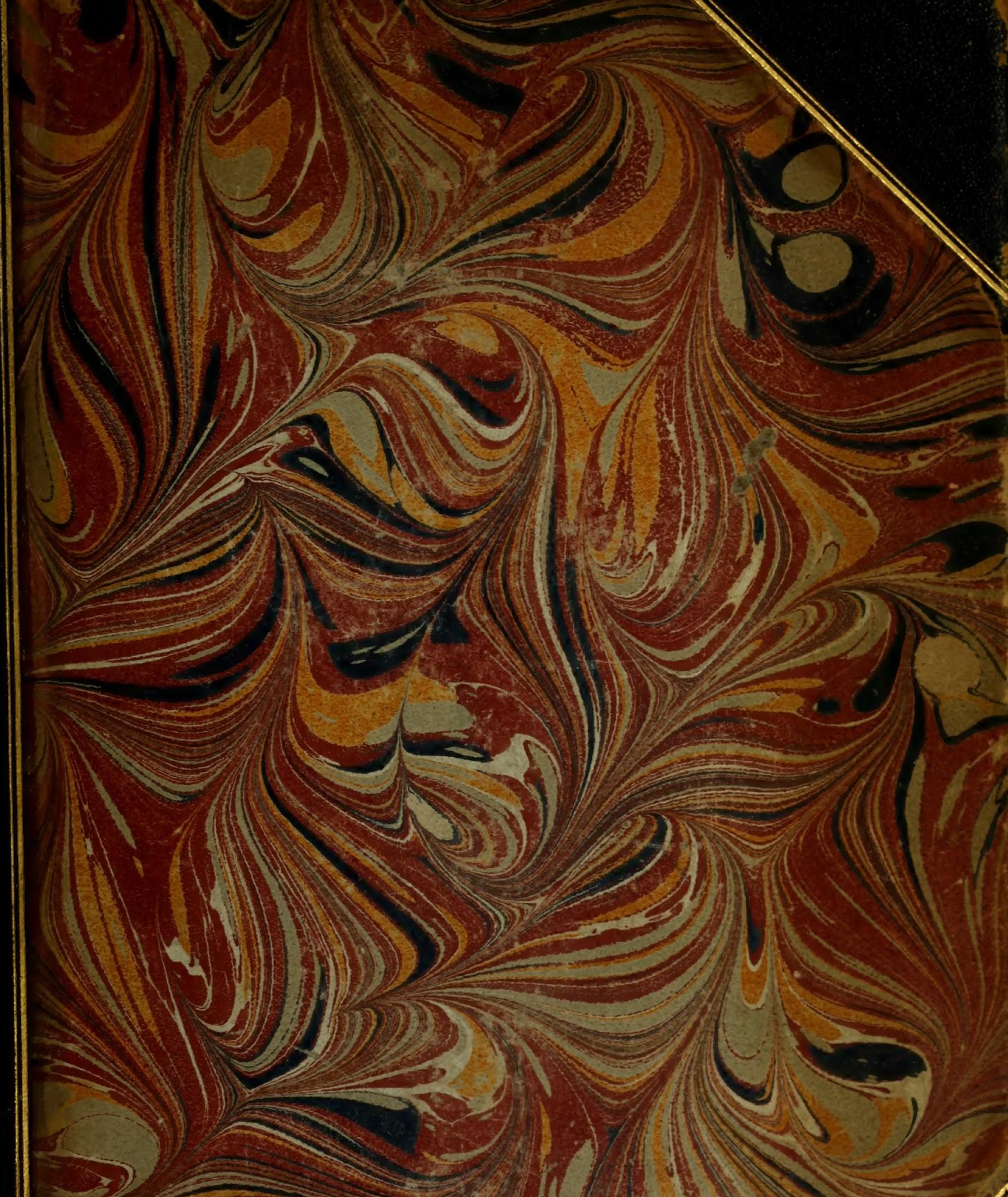




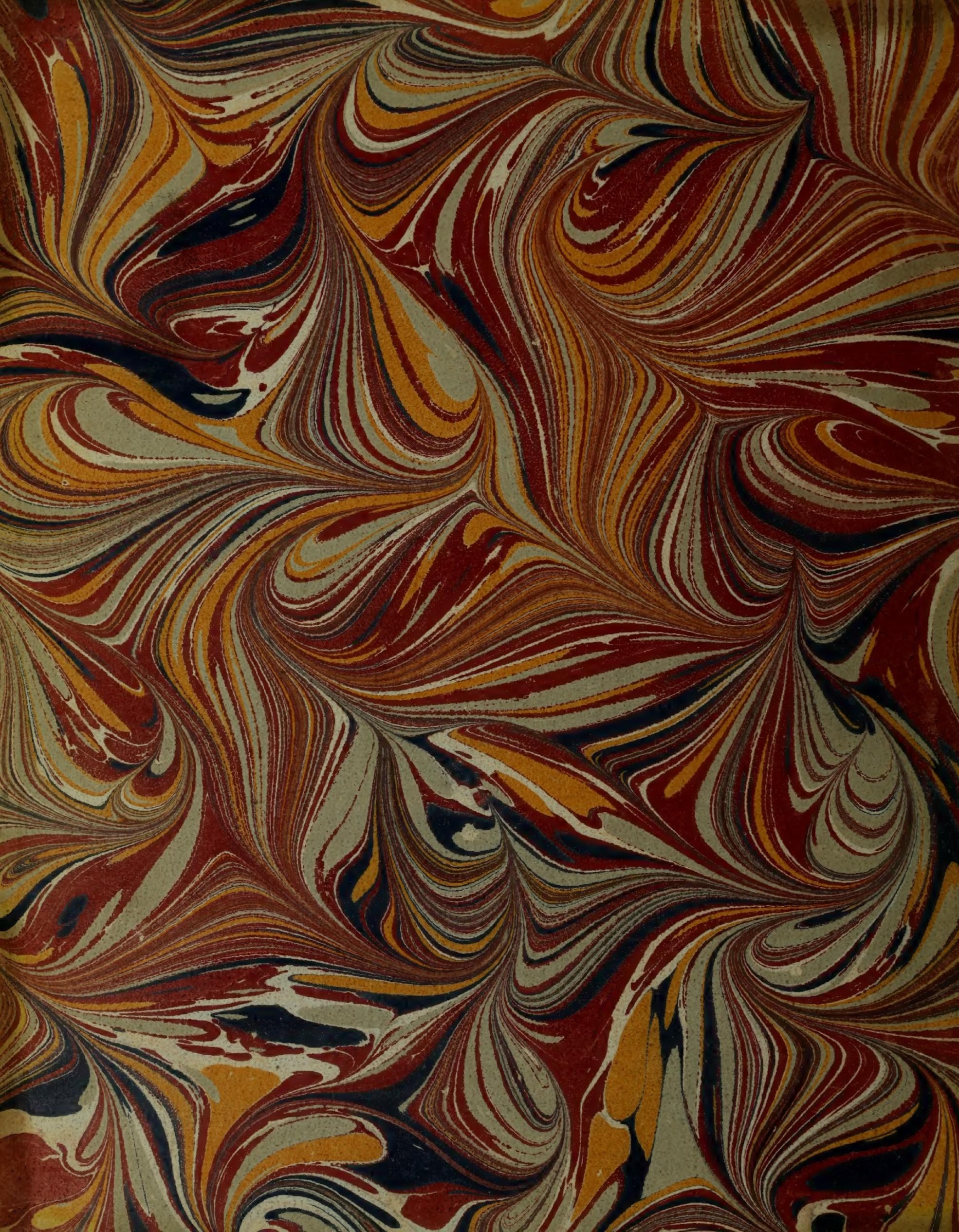




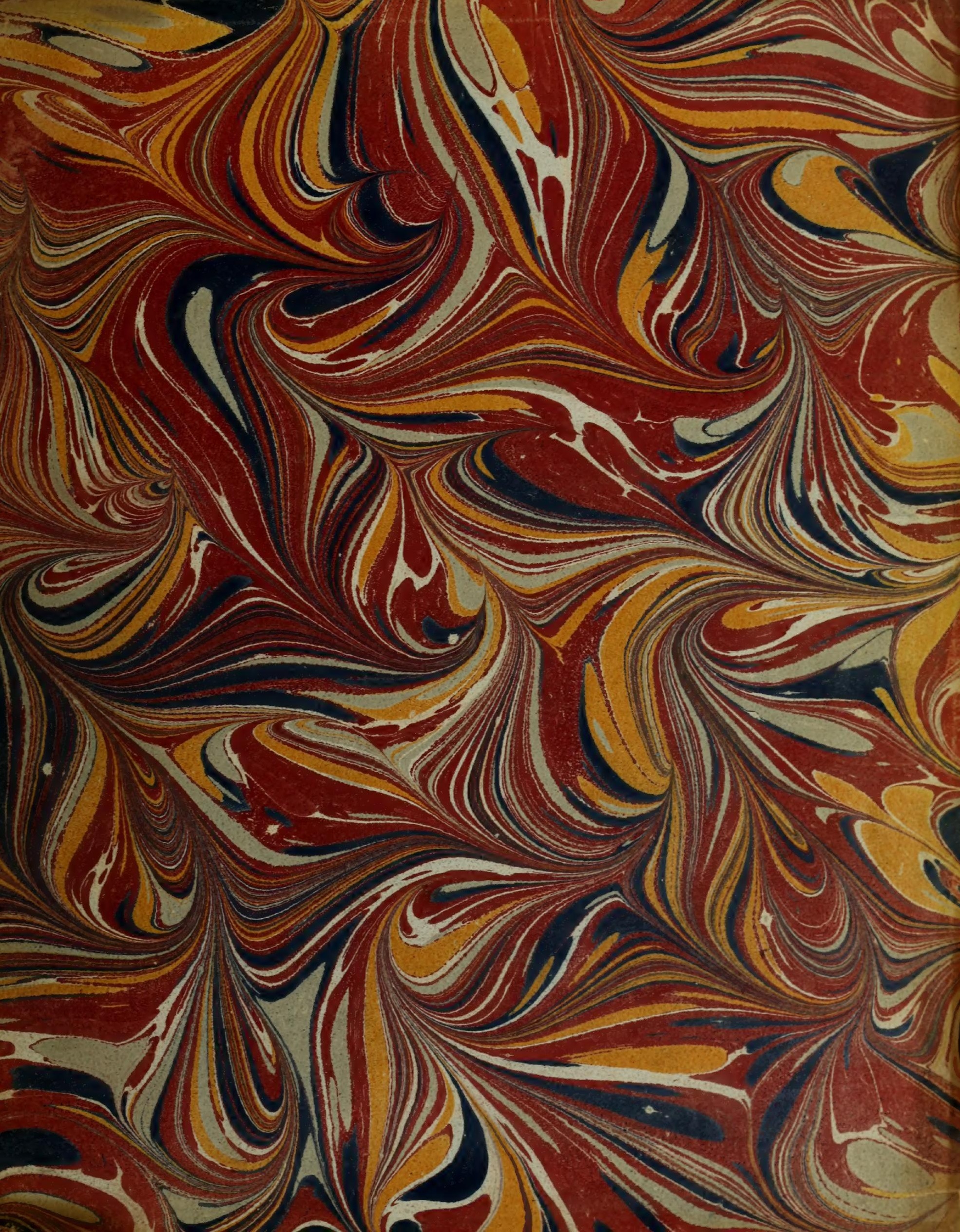


Inuat

CE

806

$14{ }^{14}$
1953 


$$
\begin{aligned}
& \text { Emst poyt Lloming } \\
& \text { Mreeum of Con a Zocha } \\
& \text { Heavard Uhiversity }
\end{aligned}
$$

$$
\text { 3. }
$$





\section{PALAONTOGRAPHICAL SOCIETY.}

INSTITUTED MDCCCXLVII.

LONDON :

MDCCCLIII. 


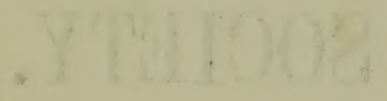

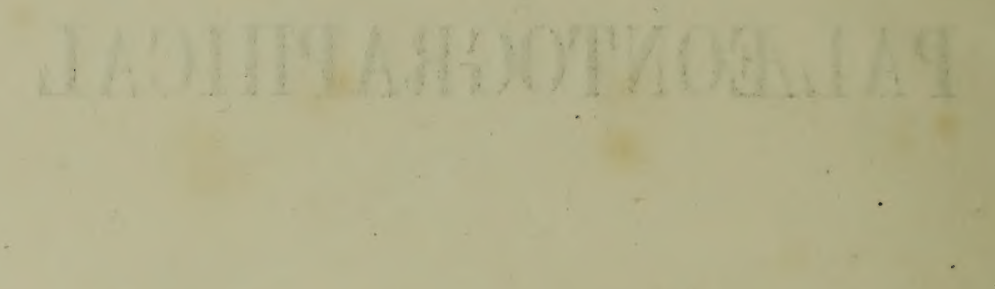

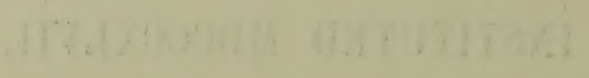

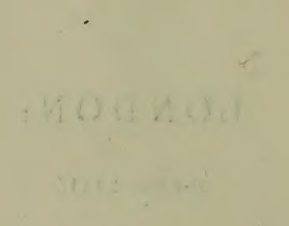




\section{PALEONTOGRAPHICAL SOCIETY.}

INSTIITUTED NDCCCXLVII.

VOLUME FOR 1909.

\section{LONDON :}

MDCcccix. 
DESCRIPTION OF THE FOSSIL REMAINS OF MOLLUSCA FOUND IN THE CHALK OF ENGLAND: CEPHALOPODA.

ORDER OF BINDING AND DATES OF PUBLICATION.

\begin{tabular}{|c|c|c|c|}
\hline PAGES & PLATES & $\begin{array}{l}\text { ISSUED IN VOL. } \\
\text { FOR YEAR }\end{array}$ & PUBLISHED \\
\hline General Title-page and Index & - & 1909 & December, 1909 \\
\hline $1-26$ & $\mathrm{I}-\mathrm{X}$ & 1853 & December, 1853 \\
\hline $27-36$ & $X I-X V I$ & 1854 & May, 1855 \\
\hline $37-68$ & XVII-XXVII & 1855 & February, 1857 \\
\hline
\end{tabular}




\title{
DESCRIPTION
}

\author{
OF THE
}

\section{FOSSIL REMAINS OF MOLLUSCA}

FOUND IN THE

\section{CHALK OF ENGLANI).}

\section{CEPHALOPODA.}

BY

DANIEL SHARPE, PRES. GEOL, SOC., F.R. \& G.S

L O N D N :

PRINTED FOR THE PALAONTOGRAPHICAL SOCIETY

1853-1909. 



\section{N D E X.}

\begin{tabular}{|c|c|c|c|c|c|}
\hline \multicolumn{3}{|c|}{ PAGE } & \multicolumn{3}{|r|}{ PAGE } \\
\hline \multicolumn{2}{|c|}{ Actinocamax verus ... } & $\quad \ldots \quad \ldots \quad 6$ & Ammonite & es navicularis & $39 ;$ xviii, $1-3,5,8$ \\
\hline Ammonites & s $\quad \ldots \quad \ldots$ & 17 & $\cdots$ & obtectus ... & $\ldots \quad \ldots \quad 20 ;$ vii, 4 \\
\hline - $\quad$ a & alternatus & $\ldots \quad \ldots \quad 32$ & - & octo-sulcatus & 42 ; xix, 3 \\
\hline- & austeni ... & $\ldots 28 ;$ xii, 1,2 & -.. & oldhami ... & 32 ; xiv, 2 \\
\hline-- & bravaisianus & $52 ;$ xxiii, 7-9 & - & peramplus & $26 ; x, 1-3$ \\
\hline - & brongniartii & $\ldots \quad \ldots \quad 22$ & - & planulatus & $\ldots 29 ;$ xii, 3,4 \\
\hline - & bunburianus & 25 ; ix, 3 & - & portlocki ... & $30 ;$ xiii, 2,3 \\
\hline - & carolinus... & $\ldots \quad 27$ & 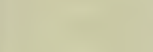 & prosperianus & $\begin{array}{lll}\ldots & \ldots & 26\end{array}$ \\
\hline & catinus ... & ... $29 ;$ xiii, 1 & 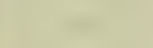 & ramsayanus & ... 51 ; xxiii, 4 \\
\hline - & cenomanensis & $\ldots 37 ;$ xvii, 1 & - & renauxianus & 41 ; xix, 2 \\
\hline- & cinctus ... & $\ldots 25 ; \mathrm{ix}, 2$ & - & renevieri... & $\ldots \quad 44 ; \mathrm{xx}, 2$ \\
\hline- & complanatus & $\ldots 19 ;$ vii, $1-3$ & & rhotomagensis & $\ldots 33 ;$ xvi, $1-4$ \\
\hline - & consobrinus & $\begin{array}{lll}\ldots & \ldots & 45\end{array}$ & & rusticus ... & $\ldots \quad 44 ; \mathrm{xx}, 1$ \\
\hline - & coupei $\quad \ldots \quad$. & . 23 ; viii, $1-4, \mathrm{ix}, 1$ & -. & salteri & $50 ;$ xxiii, 3,5 \\
\hline . & - var. inflat & ... $24 ;$ viii, 1 & - & saxbii & $\ldots \quad 45 ; \mathrm{xx}, 3$ \\
\hline - & - var. tuber & ulata 24 ; viii, 2,4 , & - & sussexiensis & 33,$34 ; x \vee, 1$ \\
\hline & & ix, 1 & & varians $\ldots$ & $\ldots 22,23 ;$ viii, $5-10$ \\
\hline- & cunningtoni & .. $\quad 35 ; \mathrm{xv}, 2$ & - & - var.cos & stata $\quad \ldots \quad 23 ;$ viii, 9 \\
\hline - & curvatus ... & 49 ; vii, 8,9 , xxiii, 1 & - & var. int & ermedia 22,23 ; viii, 7 \\
\hline - & deverianus & $\ldots 43 ;$ xix, 5 & & var. sul & bplana 22,23 ; viii, 10 \\
\hline- & euomphalus & ... 31 ; xiii, 4 & 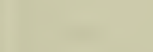 & var. sul & otuberculata 22 ; viii, \\
\hline- & falcatus ... & 21 ; vii, $5-9 ; 49$ & & & $5,6,8$ \\
\hline- & feraudianus & ... 51 ; xxiii, 6 & - & - var.tul & herculata \\
\hline- & fissicostatus & $\ldots \quad \ldots \quad 30$ & $\ldots$ & vectensis... & $\ldots \quad \ldots \quad 45 ; \mathrm{xx}, 4$ \\
\hline- & gentoni ... & $\begin{array}{lll}\ldots & \ldots & 39\end{array}$ & - & velledæ $\ldots$ & 39 ; xvii, 7 , xix, 6 \\
\hline- & gollevillensis & $\ldots \quad 48 ;$ xvii, 2 & - & vielbancii & $\begin{array}{lll}\ldots & \ldots & 37\end{array}$ \\
\hline- & goupilianus & $\ldots 38 ;$ xvii, 5,6 & & wiestii $\quad .$. & $\ldots \quad 47 ; x x i, 3$ \\
\hline & griffithii ... & $\ldots \quad 28 ; x i, 3$ & & wiltonensis & $\ldots 53 ;$ xxiii, 10 \\
\hline 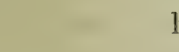 & hippocastanum & $\ldots 37 ;$ xvii, $2-4$ & - & woollgari ... & 27,$37 ; x i, 1,2$ \\
\hline . & icenicus ... & $\ldots \quad 43 ;$ xix, 4 & Aptychus & $\ldots \quad \ldots$ & $\begin{array}{lll}\ldots & \ldots & 53\end{array}$ \\
\hline - & jukesii $\quad \ldots$ & $\ldots 53 ;$ xxiii, 11 & ... & gollevillensis & $\ldots 56 ;$ xxiv, 5 \\
\hline- & largilliertianus & $\ldots \quad \ldots \quad 19$ & - & icenicus ... & $\ldots 57 ;$ xxiv, 7 \\
\hline - & laticlavius & $\ldots 31$; xiv, 1 & - & leptophyllus & $\ldots 55 ;$ xxiv, 1 \\
\hline - & leptonema & ... $32 ;$ xiv, 3 & - & peramplus... & $\ldots \quad \ldots 58 ;$ xxiv, 10 \\
\hline - & leptophyllus & 48 ; xxi, 2, xxii, 1 & - & portlocki ... & $56 ;$ xxiv, $2,3,4,6$ ? \\
\hline - & lewesiensis & 46,$48 ; \mathrm{xxi}, 1$ & - & rugosus $\ldots$ & $\quad 57 ;$ xxiv, 8,9 \\
\hline - & mantelli ... & 39,$40 ; x v i i i, 4-7$ & & & \\
\hline - & milletianus & $\begin{array}{lll}\ldots & \ldots & 39\end{array}$ & Belemnitel & & \\
\hline
\end{tabular}




\section{FOSSIL REMAINS OF MOLLUSCA IN CHALK OF ENGLAND.}

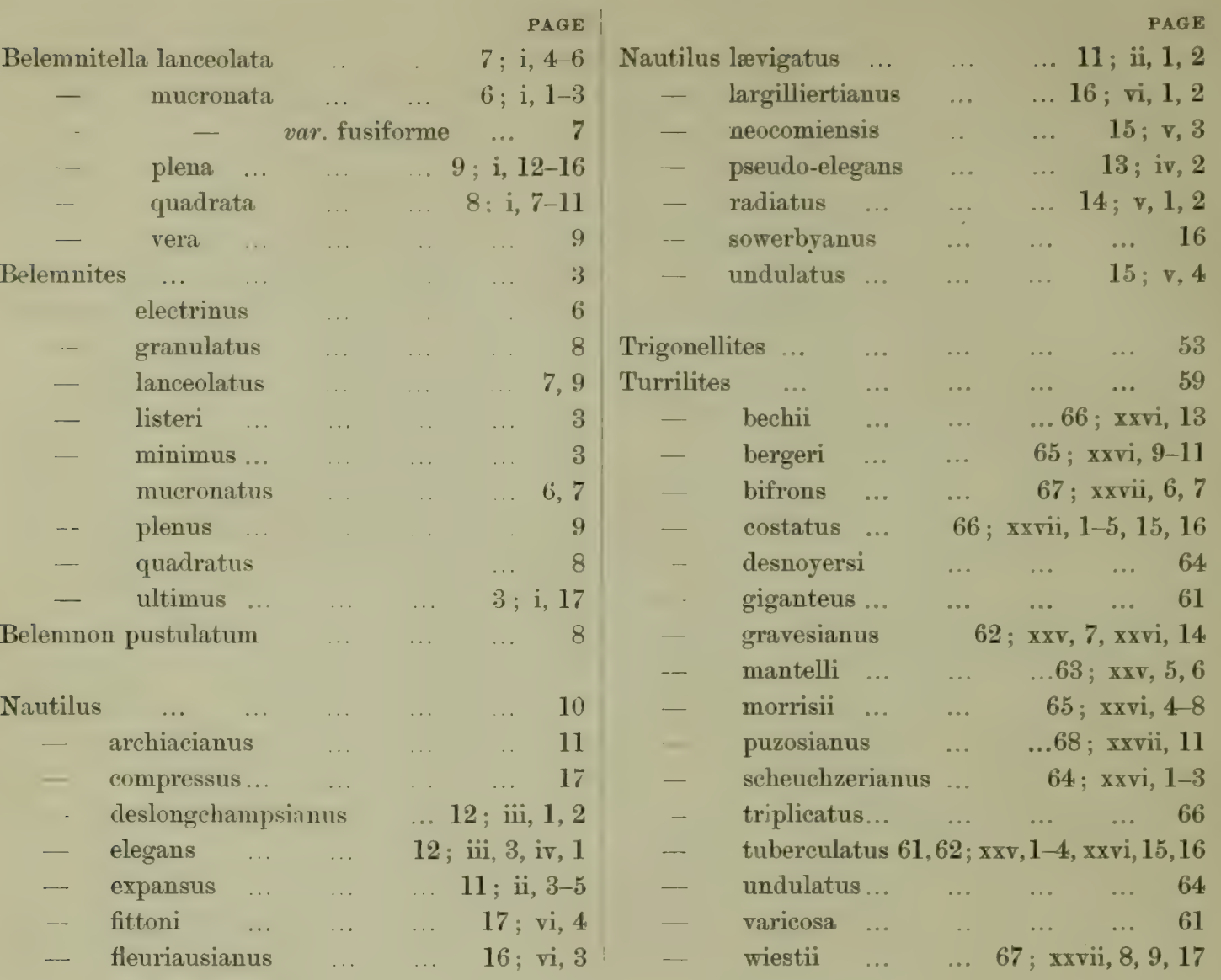




\title{
DESCRIPTION
}

\author{
OF THE
}

\section{FOSSIL REMAINS OF MOLLUSCA}

FULxנ IN THE

\section{CHALK OF ENGLAND.}

BY

DANIEL SHARPE, F.R.G. \& L.S.

PART I.

CEPHA LOPODA.

LONDON :

PRINTED FOR THE PAL\&ONTOGRAPHICAL SOCIETY.

1853. 



\section{I S T}

\section{OF THE \\ COUNCIL, SECRETARIES, AND MEMBERS \\ OP THE}

\section{PALAONTOGRAPHICAL SOCIETY,}

1859. 
Bresitent.

W. J. HAMILTON, Ese., F.R.S., For. Sec., G.S., \&c.

\section{Councít.}

PROF. G. BUSK, F.R.S., L.S., G.S., \&c. W. B. CARPENTER, M.D., F.R.S., L.S., G.S., \&c. THOMAS DAVIDSON, Ese., F.R.S., G.S., \&c. F. E. EDWARDS, EsQ. ROBERT HUDSON, EsQ., F.R.S., L.S., G.S., \&c. J. G. JEFFREY, EsQ., F.R.S., L.S., \&c. ROBERT McANDREW, Esq., F.R.S., L.S., \&c. PROF. OWEN, M.D., LL.D., F.R.S., L.S., G.S., \&c.
JOHN PICKERING, EsQ.

MAJOR-GEN. PORTLOCK, F.R.S., V.P. G.S., \&c. JOSEPH PRESTWICH, Ese, F.R. S., Treas. G.S., \&c. J. W. SALTER, Es\&., F.G.S., \&c. PROF. TENNANT, F.G.S., \&c.

S. L. WARING, Ese.

N. T. WEIHERELL, EsQ., M.R.C.S.

REV. THOMAS WILTSHIRE, M.A., F.G.S., \&C.

\section{Treasurer.}

SEARLES WOOD, EsQ., F.G.S., \&c., Twoickenham, Surrey, S.W.

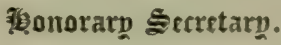

J. S. BOWERBANK, LL.D., F.R.S., L.S., G.S., \&c., 3, Bighbury Grove, Islington, N.

\section{II ocal झ̊cretaries.}

Alton . . . Writtam Curtis, Jun., Esq.

Bath . . Wr. Watton, Esq., 17, Grosvenor Place.

Birmingham $\cdot\left\{\begin{array}{c}\text { WM. MATHEws, Esq., Jun., F.G.S., } \\ \text { Edgbaston. }\end{array}\right.$

Blandford . . W. SHTPP, Esq.

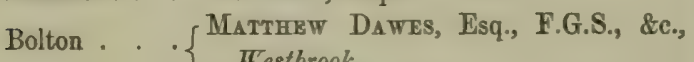

Brighton . Hestbrook.

Bristol . . . Williar Sanders, Esq., F.G.S., \&c.

Cambridge . JaMES CARTER, Esq.

Charmouth. . Henky Norkis, Esq., F.R.C.S.

Cheltenham . Thоmas Wright, M.D., F.G.S., \&c.

Cirencester . Prop. James Bockman, F.G.S., de.

Colchester . . JoHs Brown, Esq., F.G.S., \&c., Stcnoay.

Deddington . Chakles FaUlKner, Esq., F.G.S., \&c.

Devizes . . William Cunnington, Esq., F.G.S., \&c.

Dublin . . Gubert Sanders, Esq., 2, Foster Place.

Dudley . . JoHn Gray, Esq., Hagley.

Edinburgh . . \{ Pror. BaLfour, F.R.S., L.S., \&c., 2,

Edinburgh. ' $\{$ Bellevue Crescent.

Glasgow . . J J Jus P. Fraser, Esq., F.G.S., City Bank.

Gloucester . JонN W. WiLtoN, Esq.
Guildford . . R.Godwix A ustex, Esq.,F..R.S.,G.S.,\&c. Huddersfield . RoBert Welsh, Esq.

Leeds . . . Thomas Nunneley, Esq., F.R.C.S.E.

Leicester . . James Plant, Esq.

Market Rasen Rev. W. W. Cooper.

Newcastle-on- $\}$

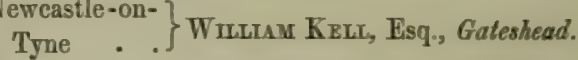

Norwich - . Robert Fitch, Esq., F.G.S., \&c.

Oxford . . . Pror.Jn.Phillips, M.A., F.R.S., G.S., \&c.

Paris . . Pror. M. Edwards, Jardin des Plantes.

Plymouth . . J. H. Fuge, Esq., F.R.C.S.E., \&c.

Portsmouth ' W. A. RAPER, M.D.

Richmond, Yorks. EDW ARD Wood, Esq., F. G.S., F.R.S.L.\&c.

Scarborough . John Leckeniy, Esq., F.G.S., \&c.

Southampton . R. Tovey, Esq., 9, Waterluo Place.

Stamford . John F. Bentley, Esq.

Stowmarket . C. R. Bree, ksq.

Torquay - . William Pexgelly, Esq., F.G.S., \&c.

Wolverhampton Hendi Becketr, Esq., Church Street.

Yarmouth . . C. B. Rose, Esq., F.G.S., \&c.

York . . Edw. Charuesworth, Esq., F.G.S., \&c. 


\section{A W S.}

I.

That the Society formed be called the Palæontographical Society, and that it shall have for its objects the illustration and description of British Fossil Organic Remains.

II.

Each Subscriber of One Guinea, or more, annually, shall be considered a Member of the Society. Such subscription to be paid in advance, and shall be due on the lst day of January, 1847, and each succeeding year.

III.

- A Member shall, for each Guinea subscribed annually, be entitled to one copy of every publication issued by the Society, for the year to which his subscription relates. But no Member shall be entitled to receive his copy, or copies, until his subscription has been paid.

IV.

The number of copies of the Society's publications shall be limited to the number of Members, unless otherwise directed by the Council.

\section{V.}

The business of the Society shall be conducted by a President, Treasurer, Hon. Secretary, and a Council of sixteen Members, who shall be elected at a General Meeting of the Members, to be held anuually in London.

VI.

The accounts of the receipt and expenditure of the Society shall be examined annually by two Auditors appointed by the Council; the Auditors to be Members of the Society, who are not Members of the Council, and their statement shall be circulated among the subscribers.

VII.

That the Editors of works published by the Society be entitled to a number of copies of their works, not exceeding twenty-five, as may be decided by the Council. 


\section{REGULATIONS FOR THE DELIVERY OF BOOKS.}

They are delivered, free of expense, within three miles of the General Post Office, London.

They are sent to any place in England, beyond the distance of three miles from the General Post Office, by any conveyance a Member may point out. In this case the parcels are booked at the expense of the Society, but the carriage must be paid by the Member to whom they are sent.

They are delivered, free of expense, at any place in London which a Member, resident in the country, may name.

They are sent to any of the Hon. Local Secretaries of the Society, each Member being expected to pay the Local Secretary a due share of the carriage of the parcel in which the books are sent.

Any number of Country Members may unite to have their books sent in one parcel to any address they may name. In this case they are requested to depute one of their number to transmit to the Secretary for London a list of the names of those whose books are to be included in the same parcel.

Those Members who wish their books to be included in any of the parcels to Local Secretaries are requested to send in their names (with their Christian name in full) and particular address to the various Local Secretaries, who are respectfully requested to forward to the Secretary for London an accurate list of all such names, with as little delay as possible.

Unless intimation to the contrary be given to the Secretary for London, the future deliveries will be made in accordance with the delivery of the first volume.

The Council, desirous of imposing as little trouble as possible upon the Local Secretaries, particularly request that all subscriptions be paid by Members directly to the Treasurer, Searles Woon, Esq., Twickenham, Surrey, by Post Office Order on the Twickenham Office, or by Cheque on a London Banker. And as there is no other capital for conducting the affairs of the Society than the Subscriptions paid in advance, the Country Menubers are respectfully reminded that an early remittance is absolutely necessary.

As the quantity of plates and letterpress to be delivered to the Subscribers annually will be increased in proportion to the extension of the Society, the Members are respectfully urged to obtain as many new Subscribers, and at as early a period, as possible.

Gentlemen desirous of forwarding the objects of the Society, may be provided with circulars for distribution by application to the Hon. Secretary. 


\section{I T OF M EMERS.}

\section{HIS ROYAL HIGHNESS THE PRINCE CONSORT,}

Abich, Dr. H. Conseiller d'Etat et Membre de l'Académie Imperial des Sciences de St. Petersburg, For. M.G.S.

Adam, Thomas, Esq. Halifax.

Addison, Rev. John, Weymouth.

Adlard, J. E. Esq. Bartholomew-close.

Agnew, Lady, Moray-place, Edinburgh.

Allingham, William, Esq. Reigate.

Ansted, Prof., M.A., F.R.S., G.S., \&c., Bon Air, St. Martin's, Guernsey.

Aplin, C. d'Oyley, H. Esq. Port Phillip, Australia.

Archæological and Natural History Society, Taunton.

Arlidge, John T., A.B., \&c. Shirley Park, Croydon.

Asher, A. Esq. Berlin.

Ashley, J. M. Lisq.

Ashmolean Society, Oxford (per Rev. E. Hill, Christchurch).

Athenæum Library, Liverpool.

Aveline, W. T., Esq., F.G.S., Museum of Practical Geology, Jermyn-street.

Austen, R. A. Godwin, Esq., B.A., F.R.S., G.S. \&c., Chilworth Manor, Guildford, Surrey.

Austin, Miss Helena E., at Rev. H. E. Howes, Frenchay, near Hambrook, Bristol.

Austen, Rev. J. H., M.A., F.G.S., \&c. Ensbury House, Wimborne.

Babington, C. C. Esq. M.A., L.S., E.G.S. \&c. St. John's College, Cambridge.

Backhouse, Wm. Esq. Conset Iron Works, Shotley Bridge, near Gateshead, Tyne.
Bagshaw, Miss, Stanley Villa, Lansdown, Cheltenham.

Baily, Wm. H., Esq., F.G.S. Geological Survey, Dublin.

Baines, Samuel, Esq. Brighouse, near Huddersfield.

Balfour, Prof., F.R.S., L.S. \&c. Edinburgh.

Balliere, H. Esq. 219, Regent-street.

Balme, E. B. Wheatley, Esq. Cotewall, Mirfield, Yorkshire.

Barclay, Joseph G. Esq. 54, Lombard-street. Barrett, Rev. A. North Cheam House, Surrey. Barr, W. R. Esq. Park Mills, Stockport.

Barthes, Lowell, and Co. Gt. Marlborough-st. Bartlett, M. Esq. Boston, U. S.

Bathurst, Rev. W. H., Darley Dale, Matlock.

Bass, Isaac Gray, Esq. Brighton.

Battersby, Robert, M.D. Torquay.

Beaufoy, George, Esq. South Lambeth.

Beckett, Henry, Esq. Church-street, Wolverhampton.

Belfast Library.

Bell, Prof., F.R.S., Pres. L.S., F.G.S. \&c. 17, New Broad-street, City.

Bell, Rev. Charles, Hampstead.

Bennett, William, Esq. 5, Bishopsgate Without.

Benson, Starling, Esq. Siransea.

Bentley, J. F. Esq. Stamford, Lincolnshire.

Bernard, Ralph M. Esq. Victoria Square, Clifton.

Bewley, John, Esq. 16, Brunswick Buildings, Liverpool.

Bidwell, Henry, M.D. Albrighton, Wolverhampton.

Bilke, Edward, Esq. F.G.S., \&c., 12, Stamford-street. 
Binney,E.W.,Esq., F.R.S.,G.S., Manchester. Binyon, T. Esq. St. Ann's-square, Manchester.

Birmingham Old Library, Union-street.

Blackburne, John George, Esq., F.G.S., Mining Engineer, Oldham.

Blackie, W. G. Esq. Ph. D., F.R.G.S., \&c., 36, Frederick-street, Glasgow.

Blackwell, S. H. Esq., F.G.S., \&c. Dudley.

Blackwell, 'Thos. E., F.G S., \&c., 65, Pulteney-street, Bath.

Bladon, James, Esq. Pontypool.

Blake, W. Esq. Bishop's Hall, Taunton.

Blount, J. H. Esq. M.B. 53, Clifton-road East, St. John's Wood.

Boase, H. S., M.D., F.R.S., G.S., \&c. Claverhouse, near Dundee.

Bohn, Henry, Esq. 4, York-street, Coventgarden.

Bonney', Rev. George, St. Peter's College, Westminster.

Booth, Prof., United States.

Borradaile, Charles, Esq. Upper Tooting.

Bosquet, M., Pharmacien, Maaestricht.

Botfield, Beriah, Esq. M.P., F.R.S., L.S., G.S., \&c., 5, Grosvenor Square.

Bouchard - Chantereaux, Mons. President de l'Administration du Museum, Boulogne.

Bower, Rev. E., Closworth, near Yeovil.

Bowerbank, J.S., LL.D., F.R.S., L.S., G.S. \&c., 3, Highbury-grove, N., Hon. Sec.

Bradley, Lonsdale, Esq., F.G.S., \&c., Prior House, Richmond, Yorkshire.

Brady, Right Hon. M., Dublin.

Brady, Antonio, Esq. Stratford, Essex, and Admiralty Office, Somerset House.

Braikenridge, Rev. G. W., F.L.S., G.S. \&c. Clevedon, near Bristol.

Bramley, Lawrence, Esq. Halifax.

Brassey, Thos. Esq. jun. 56, Lowndes-sq.

Bravender, J.C. Esq.,F.S.G.,\&c.,Cirencester.

Bree, C. R. Esq., 130, Princes Street, Edinburgh.

Briggs, Major-General, F.R.S., G.S., \&c. Oriental Club, Hanover-square.

Briggs, Miss Ellen, 3, Arlington-street.

Brighton and Sussex Natural History Society, T. B. Horne, Esq. 7, Pavilion Parade.
Bristow, Henry W. Esq. F.G.S. \&c. Museum of Practical Geology.

British Museum, Departmental Mineralogical and Geological Library.

Broome, C. E. Esq. M.A., \&c., Elmhurst, Batheaston, Bath.

Brown, John, Esq. F.G.S., \&c., Barnsly.

Brown, Isaac, Esq. Ackworth.

Brown, John, Esq. F.G.S., \&c., Stanway, near Colchester.

Brown, T. C. Esq. Cirencester.

Browne, Charles J. P. Esq. Bridgewater.

Browne, Wm. Meredith, Esq. Westminster Fire Office, King-street, Covent-garden.

Bruce, Rev. J. C., Newcastle-on-Tyne.

Brunel, I. K. Esq. F.R.S., G.S., \&c., 18, Duke-street, Westminster.

Bryson, Alexander, Esq. Edinburgh.

Buckman, Prof. James, F.G.S., \&c. Royal Agricultural College, Cirencester.

Bullock, Henry, Esq. 15, Cumberland-street, Bryanstone-square.

Bunbury, E. H. Esq. F.G.S. \&c. 15, Jermynstreet, Piccadilly.

Busk, Professor G., F.R.S., L.S., G.S., 15, Harley-street, Cavendish-square.

Butcher, Henry J. Esq. Devizes.

Byerley, Isaac, Esq. Upton, Birkenhead.

Caird, H. W. Esq. Albury Park, Guildford. Calvert, John, Esq. 189, Strand.

Cambridge University Library (per Rev. James Power).

Cann, James M. Esq. 5, Church-street, Edge-hill, Liverpool.

Carpenter, W. B. M.D. F.R.S., L.S., G.S., \&c., University Hall, Gordonsquare.

Cardiff Literary and Scientific Institution.

Carter, James, Esq. 30, Petty Cury, Cambridge.

Carter, R. Esq. Halifax.

Carter, Rev. W. A. Eton College.

Carus, Dr. Victor, Leipzig, per Williams and Norgate, 14, Henrietta-st., Coventgarden.

Catt, Henry, Esq. West-street, Brighton.

Cautley, Colonel Sir Proby T., F.R.S., G.S., \&c., 31, Sackville-street, Piccadilly. 
Cavill, Edmund, Esq. F.G.S. Saxmundham.

Cawdor, The Earl of, Trustee, British Museum, F.R.S., G.S., \&c., 74, South Audleystreet.

Chambers, Robert, Esq. F.R.S.E., G.S., \&c. Edinburgh.

Chapman, Thomas, Esq. F.G.S., 23, Newstreet, Spring-gardens.

Charlesworth, Edward, Esq. F.G.S., \&c. York.

Chariton, E., M.D. 7, Eldon-square, Newcastle-on-Tyne.

Chippenham Literary and Scientific Institution.

Chisholme, W. Esq.

Cholmeley, Mrs. Octavia, The Priory, Stroud, Gloucester.

Christy, Henry, Esq., F.G.S., \&c., 103, Victoria-street, Westminster.

Clabon, J. M. Esq., F.G.S., \&cc., 21, Great George-street.

Clapham, Thos. Richard, Esq. Austwick Hall, near Settle.

Clark, Edward, Esq. F.G.S., \&c., Sandgate, Kent.

Clark, Henry, M.D. Midland House, Southampton.

Clark, Rev. Samuel, Training Institution, Battersea.

Clark, Rev. Francis F., B.A. Malpas, near Newport, Monmouthshire.

Clark, Prof. W., F.R.S., G.S., \&c., Cambridge.

Clarke, Robert, Esq. Cincinnati, Ohio, U.S.

Clarke, Rev. W. B., F.G.S., \&c., St. Leonard's, near Sydney, New South Wales.

Clayton, Rev. J. H. Farnboro' Rectory, Bagshot.

Clennell, Jno. E. Esq. Hackney.

Cochrane, Charles, Esq. Ormsby Iron Works, Middlebro'-on-Tees.

Colchester, W. Esq., F.G.S., \&c., Harwich.

Cole, Jno. W. Esq. 18, Randolph-road, Maid Hill West.

Coles, Henry, Esq. F.G.S. \&c.24, Cambridgeroad, Hammersmith.

Colvin, Lieut.-Col. C. B. Leintwardine, near Ludlow.

Collings, Rev. W. T., F.L.S., G.S. Seigneur de Sark, Channel Islands.
Collingwood, F. S. W. Esq. Glanton Pyke, Glanton, Northumberland.

Cooke, Major A., R.E. Ord. Survey, Perth.

Cooke, W. R. Esq. Burford, Oxon.

Cooke, Rev. R. B., F.G.S., \&c. Wheldrake Rectory, York.

Cooke, Major A., R.E. Perth.

Cooper, Rev. W. H., M.A. \&c. Sussexsquare, Brighton.

Cooper, Rev. W. W. West Rasen, near Market Rasen, Lincolnshire.

Corder, Mrs. Ipswich.

Cormack, Dr., New York (U.S.)

Cornthwaite, Rev. T.M., M.A.Walthamstow

Cornwall Library, Truro.

Cotsworth, Mrs.

Cotton, R. P., M.D. \&c. 47, Clarges-street, Piccadilly.

Crewdson, W.D. Esq. Helme Lodge, Kendal.

Crowley, Alfred, Esq. Croydon, Surrey.

Crum, Walter, Esq. F.R.S. Thornliebank, Glasgow.

Cubitt, W. Esq. F.G.S. \&c. Bedford Hill, Streatham, Surrey.

Cubitt, Geo. Esq. 65, Warwick-square, S.W.

Cull, R. Esq. 19, Tavistock-street, Bedfordsquare.

Cunningham, James, Esq. 50, Queen-street, Edinburgh.

Cunnington, W. Esq., F.G.S., \&c., Devizes, Wilts.

Curtis, W. jun. Esq. Alton, Hants.

Cust, Lady Elizabeth, 13, Eccleston-square.

Darwin, Charles, Esq. M.A., F.R.S., L.S. G.S., \&c., Down, Farnborough, Kent.

Davidson, Thomas, Esq., F.R.S., G.S., Mem. Geo. Soc., France, \&c., 44, Lorn Road Terrace, Brixton.

Davis, John Ford, M.D. 13, Royal Crescent, Bath.

Daw, Robert, Esq. Customs, 3, Leigham Terrace, Plymouth.

Dawes, J. S. Esq. F.G.S., \&c. Smithwick, Birmingham.

Dawes, M. Esq. F.G.S. Westbrook, Bolton.

Dawson, Dr. J. W., F.G.S., \&c., MacGill's College, Montreal. 
Day, Alfred, D.C.L. Westbury, near Bristol. Day, Hen. Geo. Esq. B.A. St. John's Coll. Cambridge.

Deane, H. Esq. Clapham, Surrey.

De Castro, James, Esq. 5, Park Villas, Richmond.

Deshayes, Mons., For. M.G.S., Paris.

Deslongchamps, M., Eudes, For. M.G.S., Caen.

Devon and Exeter Institution, Exeter.

Devonshire, Duke of, Chancellor of the University of London, F.R.S., G.S. \&c. 10, Belgrave-square.

Dickenson, Joseph, M.D., F.R.S., L.S. \&c. 5, Nelson-street, Great George-square, Liverpool.

Dickinson, W. Esq. Shannon House, Worthington.

Dickinson, Joseph, Esq. F.G.S. Inspector of Coal Mines, Pendleton.

Dickinson, W. H. Esq̆. St. George's Hospital.

Dickinson, Henry, Esq. Coalbrook Dale.

Digby, Lady T., Mintern, near Dorchester.

Dilke, C. Wentworth, Esq., F.G.S., 76, Sloane-street.

Dillwyn, L. L. Esq. M.P., F.R.S., L.S. G.S., \&c., Hendrefoilan, Swansea.

Dixon, George, Esq. Great Eyton, near Stokesley, Yorkshire.

Donkin, Henry, Esq. 5, Paragon, New Kentroad.

Dorset County Museum Library, Dorchester.

Douglas, Rev. Robert, Stoke Lacy Rectory, Bromyard.

Dover Proprietary Library.

Dowell, Geo. M. Esq. Trinity College, Dublin.

Dratleford, Rev. D. J. Chewton, Mendip, Somersetshire.

Drewitt, R. D. Esq. Peppering, near Arundel.

Ducie, the Earl of, F.R.S., G.S., \&c., 30, Prince's Gate.

Duckworth, - Esq. Smith and Co., Booksellers, Liverpool.

Duff, Patrick, Esq. Elgin.

Dumortier, Mons. E. Lyons.

D'Urban, John, Esq. 32, Gordon-street, Gordon-square.

Durham, the Dean and Chapter of, Durham. Dymock, Rev. T. F. Ventnor, Isle of Wight
Eardley, Lady, Frognell, Torquay.

Eassie, Wm. Esq. jun. Railway Saw-mills, Gloucester.

East Sussex Medical and Chirurgical Society, Hastings (Dr. Greenhill).

Edwards, William, Esq. 9, London-street, Norfolk-square, Paddington.

Edwards, F. E. Esq. 2, John-street, Downshire-hill, Hampstead.

Edwards, Prof. Henry Milne, For. M.R.S., \&c., Jardin des Plantes, Paris.

Egerton, Sir Philip de Malpas Grey, Bart. M.P., Trustee Brit. Museum, F.R S., G.S., \&c. Oulton Park, Cheshire, and 6, Albermarle-street.

Elliot, John, Esq. Kingsbridge, Devon.

Enniskillen, William Willoughby, Earl of, D.C.L., F.R.S., G.S., \&c. Florencecourt, Enniskillen, and Athenæum.

Escher von der Linth, Arn., For. M.G.S., Zurich.

Etheridge, R. Esq., F.G.S., \&c., Museum Pract. Geology, Jermyn-street.

Evans, Thomas, M.D. Gloucester.

Eyton, Thos. C. Esq. F.L.S., G.S., \&c. Vineyard, near Wellington, Salop.

Falconer, Hugh, M.D., F.R.S.; L.S., G.S. \&c. 31, Sackville-street.

Falconer, Thomas, Esq. F.G.S., \&c., Usk, Monmouthshire.

Falkner, Frederick, Esq. Bath.

Falkner, Thomas Alexander, Esq. M.A. Weymouth.

Farnham, Lord, Carlton Club, 94, Pall Mall.

Farrer, J. W. Esq. F.G.S. \&c. Ingleborough, Yorkshire.

Faulkner, Charles, Esq. F.S.A., G.S. Museum, Deddington, Oxon.

Favre, M. Alph., Prof. Geology, Academy, Geneva.

Fenton, James, Esq. M.A., Grappenhall, Lodge, near Warrington.

Ferguson, Daniel, Esq. Coatham Redcar, Yorkshire.

Ferguson, W. Esq. 26, Lloyd-square, Pentonville.

Ferguson, Wm. Esq. F.G.S. 31, Torringtonsquare. 
Fisher, Rev. J. H., F.G.S. \&c. Kirby Lonsdale.

Fisher, Rev.Osmond,M.A. F.G.S.Colchester.

Fitch, Robert, Esq. F.G.S. \&c. Norwich.

Fitton, W. H., M.D., F.R.S., L.S., G.S., \&c. 4, Sussex Gardens, Hyde Park.

Fletcher, T. W. Esq. F.R.S., G.S., S.A., \&c. Dudley, Worcestershire.

Flower, J. W. Esq. Park Hill, Croydon.

Forchhammer, George, PH. D., For. M.G.S. Copenhagen.

Fox, Rev. W. D. Delamere Forest, near Chester.

Fraser, James P. Esq. F.G.S. City Bank, Glasgow.

Fraser, John, M.D. Wolverhampton.

French, Richd. Esq. Trin. Coll., Cambridge.

Froggat, John, Esq., Church-gate, Stockport.

Fryer, A. Esq. Chatteris, Cambridgeshire.

Fuge, J. H. Esq. F.R.C.S.E. Plymouth.

Fuller, Henry J., M.D. 13, Manchestersquare.

Gatty, Charles, Esq. Felbridge Park, East Grinstead.

Galton, Douglas, Esq. R.E., F.G.S., \&c. 19, Chester-street, Grosvenor-place.

Gandy, Gerard, Esq. Kendal.

Gassiot, I. P. Esq. F.R.S. \&c. Clapham.

Gavey, George E. Esq. F.G.S., \&c.

Geological Society of Dublin.

Geological Society of Manchester.

Geological and Polytechnic Society of the West Riding of Yorkshire, Leeds.

Geslin, M. Berthaud, Paris.

Gibson, G. S. Esq. Saffron Walden.

Gibson, Thos. F. Esq. F.G.S. \&c. 124, Westbourne-terrace, Hyde-park.

Gilchrist, Dr. Royal Institution, Dumfries.

Glossop, F. H. N. Esq. Isleworth.

Godlee, Rickman, Esq. Lillies, Upton, Essex.

Gomonde, W. H. Esq. F.G.S. \&c.

Gordon, P. L. Esq. Craigmyle.

Gough, Thomas, Eisq. Preston Hall, Kendal.

Gough, Capt. the Hon. G. S., F.L.S., \&c. Rathnonan, House, Clonmel, Ireland.

Gould, John, Esq. F.R.S., L.S., Z.S., \&c. Broad-street, Golden-square.

Graham, Cyril, Esq.
Gratton, Joseph, Esq. 32, Gower-street.

Gray, C. Esq. Bliston.

Gray, John, Esq. Lyttleton-terrace, Hagley, near Stourbridge.

Gray, Thos.Esq. 37, Montieth-row, Glasgow.

Greene, Prof. J. B., Cork.

Griesbach, Rev. A. W. Wollaston, Wellingborough, Northampton.

Griffith, Edw. Esq. F.R.S., \&c. Common Pleas Office, Serjeant's Inn, Chancerylane.

Griffith, N. Esq. F.G.S., \&c. Dublin.

Griffith, Sir Richard, Bart., LL.D., F.G.S., \&c. Dublin.

Grosvenor, Horace, Esq. Cincinnati, Ohio, U.S.

Grundy, Thomas, Esq. Northampton.

Gruner, M. Louis, Directeur de l'Ecole Imperiale des Mines, \&c. St. Etienne, Loire, France.

Guise, W. V. Esq. F.G.S. \&c. Elmore-court, near Gloucester.

Hagenow, Chevalier Frederic de, Рн. D. \&c. Griefswald, Pomerania.

Hall, Robert, Esq. 8, Dean's-yard, Westminster.

Hall, William, Esq., Feversham, Kent.

Hall, Robert W. Esq. F.G.S. Raglan House, Wheath, Glamorganshire.

Hall, James, Esq. For. M.G.S. Geological Survey, States Library, Albany, New York, U.S.

Halle, University, Library of.

Hambrough, B. J. Esq. F.G.S. Niton, I.W.

Hamilton, E. M.D., F.L.S., 22, Graftonstreet, Bond-street.

Hamilton, W. J. Esq. F.R.S., For. Sec. G.S., 23, Chesham-place, Pimlico.

Hansfield, J. Esq.

Hanson, Samuel, Esq. Botolph-lane.

Harkness, Prof. Robert, F.R.S., G.S., Queen's College, Cork.

Harmar, Richard, Esq. 9, Brock-street, Bath.

Harris, W. Esq. F.G.S. Charing, Kent.

Harrison, Wm. Esq. Galligreaves House, Blackburn.

Hastie, Alexander, Esq. M.P. \&c. Glasgow.

Haughton, Prof. S., M.A., F.R.S., G.S. Trin. Coll., Dublin. 


\section{- LIST OF MEMBERS.}

Hawes, Rev. Henry, B.A., F.L.S. \&c. Southsea, Portsmouth.

Hawkins, M. R. Esq. 4, Stanhope-street, Hyde Park Gardens.

Hawkins, B. Waterhouse, Esq. F.L.S., G.S. Belvidere-road, Norwood.

Heales, Alfred, Esq. Doctors' Commons.

Hector, James, M.D.Edinburgh (Maclachlan and Stewart).

Henslow, Rev. John S., M.A., F.L.S., G.S. and C.P.S. Prof. Bot. Camb., Hitcham, Bildeston, Suffolk.

Heywood, James, Esq. F.R.S., G.S. \&c. Athenæum.

Higgins, E. T. Esq. 10, Brook-terrace, Birkenhead.

Highley, Samuel, Esq. jun. F.G.S. Box Hill, Surrey.

Hill, Miss, Rock House, Bath.

Hills, William Henry, Esq. Sunderland.

Hitchman, Dr. John, County Asylum, Derby.

Holmes, George B. Esq. Horsham.

Hony, Rev. W. E., F.G.S. \&c. Archdeacon of Sarum, Baverstock, near Salisbury.

Hopgood, James, Esq. Clapham Common.

Hopkins, W. Esq. M.A., F.R.S., G.S. Cambridge.

Horner, Leonard, Esq. F.R.S., G.S. 17, Queen's Road West, Regent's Park.

Horner, Rev.John S. Mello Park, near Frome.

Howard, Mrs. Greystoke Castle, Penrith.

Howitt, Thomas, Esq. Lancaster.

Hoyland, Chas. Esq. 16, Old Broad-street.

Hudson, Robert, Esq. F.R.S., G.S. Clapham.

Huguenin, O. F. U. T. Esq. Java.

Hull, Edward, Esq. F.G.S. \&c. Museum Pract. Geology, Jermyn-street.

Hull, Edwd. Esq., Manor House, Little Hampton, Bengworth, Eversham.

Hull, W. D. Esq. F.G.S. \&c. 49, Milnersquare, Islington.

Hunt, Z. D. Esq. F.G.S. Aylesbury.

Hunter, Rev. S. Wolverhampton.

Hunter, Rev. Robert.

Hutchins, Miss, Alton, Hants.

Hutton, R. Esq. F.G.S., M.R.I.A. \&c. Putney Park.

Huxley, T. H. Esq. F.R.S., L.S., Sec. G.S., Museum Practical Geology, Jermyn Street.
Illingworth, Rev. E. A. 3, Mecklenburgh street, Mecklenburgh-square.

Illingworth, R. S. Esq. 9, Norfolk-crescent. Ilott, James, Esq. Bromley, Kent. Ipswich Museum, Ipswich.

Jackson, W. Esq. Newton, near Penrith.

Jackson, Edward S. Esq. M.A., F.G.S. \&c. Totteridge House, Enfield Highway, Middlesex.

James, Lieut.-Col. H., R.E., F.R.S., G.S. \&c. Ordnance Survey, Southampton.

Jardine, Sir Wm. Bart. F.R.S. E., F.L.S. \&c. Jardine Hall, Lockerby, N.B.

Jarvis, Richard H. Esq. F.G.S. 24, Dorsetsquare.

Jeffreys, J. G. Esq. F.R.S., L.S. 1, Montague-square.

Jennings, F. M. Esq. M.R.I.A. \&c. Cork.

Johnes, J. Esq. F.G.S. Dolan Cothi, Llandilo, North Wales.

Johnson, William, Esq. Eton College.

Jones, Rear-Admiral T., M.P., F.L.S., G.S. \&c. 30, Charles-street, St. James's.

Jones, John, Esq. Gloucester.

Jourdain, Dr. Director, Museum, Lyons.

Jukes, J. B. Esq. M.A., F.R.S., G.S. \&c. Geological Survey of Ireland, Stephen'sgreen, Dublin.

Keal, John, Esq. Bellevue-house, Bristol.

Kell, William, Esq. Gateshead, near Newcastle-on-Tyne.

Kenyon, the Hon. Mrs., Parade, Shrewsbury.

Kenyon, J. R. Esq. British Museum.

King, Prof. W. F.G.S. Prospect-hill, Galway.

King, W. P. Esq. Rodney-place, Clifton, Bristol.

Königliches Ober Berg. Amt. Bonn.

Kingston, G. S. Esq. Grote-street, Adelaide, S. Austrailia.

Knapp, Charles, Esq. 2, Harcourt-buildings, Temple.

Krantz, M. Bonn.

Kuprainoff, Lieut,-Col., St. Petersburg.

Laidlay, John W. Esq. Calcutta, and Hindon, near Arundel.

Landseer, George, Esq. Cunningham-place, St. John's Wood. 
Lankester, Edwin, M.D., LL.D., F.R.S. L.S. 8, Savile-row, Bond-street.

Lashmar, Dr. C. Croydon.

Law, Rev. Julius, Conran, Durham.

Lawrance, John, Esq. F.G.S. Elton, Oundle. Leckenby, Jno. Esq. F.G.S. Scarborough.

Lee, John, LL.D., F.R.S., R.A.S., G.S. \&c. 5, College, Doctors' Commons.

Lee, Jno. Edward, Esq. F.G.S. The Priory, Caerleon, Monmouthshire.

Leeds Library, Leeds, Yorkshire.

Leigh, Dr. J. S., 7, St. Stephen's-terrace, Westbourne Park.

Lesson, E., M.D., Bonchurch, Isle of Wight.

Lemon, Sir C. Bart. F.R.S., G.S. \&c. 40, Charles-street.

Library of the University, King's College, Aberdeen.

Lidstone, Roger, Esq. Plymouth.

Lindsay, Chas.Esq. 10, Addle-street, Doctors' Commons.

Lingard, Jno. R. Esq. Alderley, near Wilmslow, Cheshire.

Lister, J. J. Esq. F.R.S. \&c. Upton, Esssex.

Lister, Jno., M.D., F.G.S. \&c. Shibden Hall, near Halifax.

Lister, Rev. W. Bushbury, Staffordshire.

Literary and Philosophical Society of Sheffield.

Literary and Philosophical Society of Newcastle.

Literary and Philosophical Institution, Cheltenham.

Liveing, G. E. Esq. St. John's College, Cambridge.

Liverpool Free Public Library (J. S. Dalton, Esq.)

Llewelyn, J. D. Esq. F.R.S., L.S. \&c. Pentlegare, Swansea.

Llewellen, W.jun.Esq.F.R.S.\&c. Pontypool.

Lloyd, John, Esq. 77, Snow-hill.

Lloyd, Frederick, Esq. S0, Dorset-square.

Long, H. W. Esq. Rood Ashton, Trowbridge.

London Institution, Finsbury Circus.

Longman, Messrs. and Co. Paternoster-row.

Lonsdale, W. Esq. F.G.S. Burnham, Bridgewater.

Lorière, Mons., Jardin des Plantes, Paris.

Lovén, Prof. S., Stockholm.

Low and Son, Ludgate-hill.
Lowry, J. W. Esq. F.R.G.S. 45, Robertstreet, Hampstead-road.

Lubbock, Sir John W. Bart. M.A., F.R.S., L.S., G.S. Mansion-house-street.

Ludlow Natural History Society.

Lury, S. H. Esq. 16, Old Board-street.

Lyell, Sir C., M.A., F R.S., L.S., G.S. \&c. 53, Harley-street, Cavendish-square.

Mackeson, Henry B. Esq. F.G.S. \&c. Hythe, Kent.

Mackey, Lieut.-Col., Fairhill, near Exeter.

Maclaren, Charles, Esq. F.R.S.E., G.S. \&c. Moreland Cottage, Grange, Edinburgh.

Maclean, William C. Esq. St. Ann's Thicket, Portsea.

Macleod, John, M.D., H.M.S. Hermes.

McAndrew, R. Esq. F.R.S. Allhallows Chambers, Lombard-street.

McDowell, Geo. Esq., Dublin.

McDowell, G. M. Esq. F.T.C.D., Trinity College, Dublin.

McIntosh, John, Esq. Taunton.

Macredie, P.B.M. Esq. Perceton Irvine, N.B.

Majendie, A. Esq. F.R.S., G.S. \&c. Hedingham Castle, Castle Hedingham, Essex.

Major, Charles, Esq. Red Lion Wharf, Upper Thames-street.

Malta Library, Malta.

Mansell, John, Esq. Cossington, Bridgewater.

Marcou, Professor of Geology, Zurich.

Marier, Mons. Paul, 10, Rue Blanche, Paris.

Marsh, John, Esq. Burnt Tree, near Dudley.

Marshall, James G. Esq. M.P. Leeds.

Marshall, Matthew, Esq. Bank of England.

Martin, P. J. Esq. F.G.S. \&c. Pulborough.

Martineau, F. Edgar, Esq. 42, George-street, Edgbaston, Birmingham.

Matthieson, James, Esq. 19, Belitha-terrace, Barnsbury Park.

Matthews, W. jun. Esq. F.G.S. Edgbaston, Birmingham.

Maw, G. Esq. Barratt's-hill House, Broseley, Salop.

Meade, Rev. R. J. Castle Cary.

Mechanics' Institution, Lewes.

Mechanics' Institution, Llandilo.

Mechanics' Institution, Leicester. 
Medlock, Henry, Esq. Great Marlboroughstreet.

Melbourne University Library, Australia.

Melville, Prof. M.D. \&c., Queen's College, Galway.

Merian, Prof. Directeur de Museum, Basle.

Meryon, Edward, M.D. F.G.S. 14, Clargesstreet.

Middleton, John, Esq. 63, St. Stephenstreet, Norwich.

Mitchell, Dr. J. F.R.S. King-street, Kilmarnock, Ayrshire.

Mitchenson, John, Esq. 56, South-street, Durham.

Mohr, Ernest, Herr, Heidelberg.

Mold, W. H. Esq. Aldersley, Derbyshire.

Molini, Charles Frederick, Esq. 17, King William-street, West Strand.

Monk, Jas. Esq. Aden Cottage, Durham.

Moore, J. C. Esq. F.R.S., G.S. \&c. 4, Hyde Park Gate, Kensington.

Moore, Charles, Esq. F.G.S. Cambridgeplace, Widcome-hill, Bath.

Moore, Joseph, Esq. 25, Park Terrace, Brixton-road.

Morant, A. W. Esq. F.G.S. 2, Britanniaterrace, Great Yarmouth.

Morgan, Rev. William Leigh, Cardiff.

Morgan, William, Esq. Swansea.

Morris, John, Professor, F.G.S. Kensington.

Morson, T. N. Esq. Southampton-row, Russell-square.

Morton, George Highfield, Esq. 5, Londonroad, Liverpool.

Mosley, Sir Oswald, Bart. D.C.L., F.L.S., G.S. \&c. Rolleston Hall, Burton-onTrent.

Murchison, Sir R. I., G.C.St.S., M.A., D.C.L., F.R.S., G.S., L.S. \&c. 16, Belgrave-square.

Murdock, William, M.D. 320, Rotherhithe.

Museum of Practical Geology, Jermyn-street.

Neale, Edward V. Esq. West Wickham, Kent.

Neale, T. C. Esq. Chelmsford.

Neale, Henry, Esq. Foxhangers, Devizes.

Neison, Francis, G. P. Esq. F.L.S. \&c. 3A, St. James's-square.

Nelson, Lieut.-Col. R. I., R.E. 9, Molesworth-terrace, Stoke, Devonport.
New York State Library, Albany, U.S.

Newman, Edward, Esq. F.L.S. \&c. 9, Devonshire-street, Bishopsgate-street.

Norfolk and Norwich Literary Institution.

Norris, Henry, Esq. F.R.C.S. \&c. Charmouth, Dorset.

Norton, J. H., M.D., F.G.S. \&c. Amroath Castle, near Tenby.

Nunneley, Thomas, Esq. Leeds.

Nutt, David, Esq. 270, Strand.

Oldham, Prof. 18, Pembroke-road, Dublin.

Olivier, Lieut.-Col. H. S. Pottern Manor, Devizes.

Ormerod, G. W. Esq. M.A., F.G.S. \&c. Chagford, Exeter.

Owen, R., Professor, M.D., LL.D., F.R.S., L.S., G.S., \&c. British Museum.

Paine, Mrs. Farnham.

Papillon, Rev. J. Lexden.

Parry, Thomas G. Esq. F.G.S. Highnam

Court, near Gloucester.

Pattisson, Mrs. Jacob, Witham, Essex.

Payne, Rev. Wm. Reading.

Paynter, Rev. Samuel, Stoke Hill, Guildford,

Surrey.

Peace, William, Esq. Haigh, near Wigan.

Pearson, Sir Edwin, K.H., M.A., F.R.S. \&c.

7, Chester-terrace, Regent's Park.

Pease, Thomas, Esq. Henbury, near Bristol.

Peckover, Algernon, Esq. F.L.S. Wisbeach.

Pengelly, William, Esq. F.G.S. Torquay.

Penny, Rev. James, M.A. \&c. Blandford.

Penruddocke, Charles, Esq. Compton Park, near Salisbury, and 12, Hereford-street, Oxford-street.

Perkins, Rev. R. B. Wotton-Underedge, Gloucestershire.

Perry, George, Esq. Croydon, and Charter House.

Pertz, Dr. Berlin.

Phillips, Prof. John, M.A., F.R.S., G.S. \&c. Magdalen Bridge, Oxford. .

Philosophical Society of Glasgow.

Philosophical Society, Leicester.

Philosophical Society, York.

Phear, Rev. Sam. Geo., Emmanuel College, Cambridge. 
Pickering, John, Esq. Tufnell-park-road, Upper Holloway.

Pictet, Prof. Geneva.

Pidgeon, Jonathan S. Esq. Pembridge Villa, Bayswater.

Pierson, Charles, Esq. Blenheim Parade, Cheltenham.

Plant, James, Esq. Princess-street, Leicester. Plomley, F., M.D., F.L.S. \&c. Maidstone.

Pollock, Lady, Clapham-common.

Portal, Wyndham S. Esq. Malshanger House, Basingstoke.

Portlock, Major-General,LL.D.,F.R.S., G.S. \&c. 58, Queen's Gardens, Hyde Park, W.

Portman, Hon. Miss, 5, Prince's Gate, Hyde Park.

Powles, T. W. Esq. 46, Wimpole-street.

Pratt, S. P. Esq. F.R.S., L.S., G.S. \&c. 25, Thurlow-square, Brompton, S.W.

Preston Literary and Philosophical Institution.

Prestwich, Joseph, Esq. F.R.S., G.S. 10, Kent-terrace, Regent's Park Road.

Pritchard, Rev.C., M.A., F.R.S.\&c. Clapham.

Prout, Rev. E., F.G.S. \&c. Mission House, Blomfield-street, Finsbury.

Provis, William A. Esq. The Grange, Ellesmere, Salop.

Queen's College, Galway.

Raban, Major, Junior United Service Club, Regent-street.

Radcliffe Library, Oxford.

Ramsay, Prof. A. C., F.R.S., G.S. \&c. Museum of Practical Geology, Jermynstreet.

Ramsay, William, Prof. of Humanity, University of Glasgow.

Rankin, R. M.D. Carluke, Glasgow.

Ranlin, Professor, Bordeaux.

Ransome, Mrs. Robert, Ipswich.

Raper, W. A., M.D. Parade, Portsmouth.

Rashleigh, J. Esq. 3, Cumberland-terrace, Regent's Park.

Rich, Messrs. 12, Tavistock-row, Coventgarden.

Richardson, W. S., Esq. F.G.S. \&c. 26, Dorset-place, Dorset-square.
Richardson, William, Esq. Southeram, near Halifax.

Risley, Rev. William Cotton, M.A. Deddington, Oxfordshire.

Robbins, George S. Esq. F.G.S. Midford Castle, near Bath.

Roddam, Jonathan, Esq. Newhouse, Weardale, Durham.

Rofe, John, Esq. F.G.S. \&c. Preston.

Roots, William, M.D., F.S.A. \&c. Surbiton, Kingston, Surrey.

Roper, F. C. S. Esq. F.G.S., L.S. Pemburyroad, Clapton.

Rose, C. B. Esq. F.G.S. \&c. 28, King-street, Gt. Yarmouth.

Rosling, A. Esq. Southwark Bridge Wharf.

Rosser, W. H. Esq. 60, King-street, Stepney.

Rothery, H. C. Esq. M.A., F.L.S. 94, Gloucester-terrace, Hyde-park.

Rothery, Charles W. Esq. Greta Hall, Keswick.

Royal Artillery Institution, Woolwich.

Royal Agricultural College Library, Cirencester.

Royal College of Surgeons.

Royal Dublin Society.

Royal Geological Society of Cornwall, Penzance.

Royal Institution, Edinburgh.

Royal Institution, Liverpool.

Royal Institution of South Wales, Swansea.

Royal Irish Academy, Dublin.

Royal Military College, Sandhurst, Bagshot.

Rudd, Rev. Leonard H. M.A. Twyford, Reading.

Russ, James, Esq. F.G.S. Clovelly Lodge, Abbey Wood, Kent.

Rutter, John, Esq. Ilminster.

Sabine, General, R.A., F.R.S., L.S., \&c. 13, Ashley-place, Westminster.

Salter, J. W. Esq. F.G.S. \&c. Museum of Practical Geology, Jermyn-street.

Sanders, W. Esq. F.G.S. \&c. 21, Richmondterrace, Clifton, Bristol.

Sanders, Gilbert, Esq., M.R.I.A. \&c., 2, Forster-place, Dublin.

Sandwith, Thos. M.D., Beverley, Yorkshire. 
Sanford, W. A. Esq. F.G.S. Nynehead-court, Wellington, Somerset.

Sansom, Thomas, Esq., 7, Everton-street, Liverpool.

Saunders, W. Wilson, Esq. F.R.S., L.S. \&c. Lloyds'.

Saxby, S. H. Esq.

Scarborough Philosophical Society.

Schlumberger, Jos. K. Esq. Mulherese, France.

Schrieber, Lady Charlotte, 18, King's Armsyard, Moorgate-street.

Schultz, Mons, Guillermo, Paris.

Schumard, Dr. B. F., per Bailliere and Co.

Scott, J. B. Esq. M.A. Bungay, Suffolk.

Scott, Capt. R. E. 6, Clarence-place, Woolwich.

Sedgwick, Rev. Adam, M.A., F.R.S., G.S. \&c. Cambridge.

Selwyn, A. R. C. Esq. Geological Surrey Office, Melbourne.

Sentenis, - Esq. per Longman \& Co.

Sharman, George, Esq., 7, Belgrave-terrace, Abbey-wood, St. John's-wood.

Sharp, Samuel, Esq. Stamford.

Sharp, John, Esq. F.G.S. Culverden Castle, Tonbridge Wells.

Shaw, John, M.D., F.G.S. \&c. Hop House, Boston, Lincolnshire.

Sherman, Rev. James, Paragon, Blackheath.

Sheppard, T. Byard, Esq. Selwood Cottage, Frome.

Sheppard, Alfred B. Esq., Torquay.

Shipp, W. Esq. Blandford, Dorset.

Sidney Sussex College Library, Cambridge.

Silurian Society, Bytown, U.S., per Bailliere and $\mathrm{Co.}$

Sims, W. D. Esq. Ipswich.

Simms, George, Esq. Bathwick-hill, Bath.

Simpkin, Marshall, and Co., Messrs., Stationers' Hall Court, E.C.

Simpson, S. Esq. The Greaves, Lancaster.

Sloper, George E., Esq. Devizes.

Smith, James, Esq. F.R.S.L. \& E., G.S. \&c. Jordan Hill, near Glasgow.

Smith, Captain Robert, Frankfort Avenue, Rathgar, Dublin.

Smith, Samuel, Esq. Wisbeach.

Smith, Rev. Charles, Lesingham, Little Canfield Rectory, near Chelmsford, Essex.
Smithe, Rev. Frederick, M.A., F.G.S. Churchdown, Cheltenham.

Sismonda, M. Angelo, Prof. of Mineralogy, For. M.G.S. Turin.

St. Marc, Mons. Meaux, Rue Hautesville, No. 19, Paris.

St. Peter's College, Cambridge (Rev. Dr. Cookson).

Sopwith, T. Esq. F.R.S., G.S. 43, Cleveland Square, Hyde Park.

Sorby, H. C. Esq. F.R.S., G.S. Broomfield, Sheffield.

Sowerby, James de Carle, Esq. F.L.S. \&c. Royal Botanic Gardens, Regent's Park.

Sparrow, Arthur, jun. Esq. Wolverhampton.

Spence, W. Esq. F.R.S., L.S. \&c. 18, Lower Seymour-street.

Spragge, W. K. Esq. Paignton, near Torquay. Spratt, Thomas, Capt. R.N., F.R.S., G.S. Tynemouth, Devon.

Stamford Institution.

Stansfield, James, Esq. Halifax.

Stevens, H. Esq. F.G.S. \&c. The Shaws, Matlock, Derbyshire.

Stewart, John, Esq. F.R.S.E. \&c. Poulton- le-Sands, near Lancaster.

Studer, Prof., For. M.G.S., Berne.

Sunderland Corporation Museum, per John Evans, Esq. M.B.

Tate, George, Esq. F.G.S. \&c. Alnwick.

Taylor, John, Esq. F.R.S., L.S., G.S. 6, Queen's-place, Upper Thames-street.

Taylor, S. Watson, Esq. Urchfont, Devizes. Teale, T. P. Esq. F.L.S. \&c. Leeds.

Tennant, Prof. Jas. F.G.S. \&c. 149, Strand (two copies).

Teschemacher, Frederick, Esq. 4, Parkterrace, Highbury.

Thiolliere, M. Victor, 19, Rue St. Dominique, Paris.

Thomas, F. W. L. Esq. Lieut. R.N., Trinity, near Edinburgh.

Thompson, Miss S. Stamford.

Thompson, Jas. Esq. Netherfield, Kendal.

Thomson, Alexander, Esq. F.R.S.E. Banchory House, Aberdeen.

Thomson, Dr. Allen, Prof. Anatomy, University, Glasgow.

Thomson, Prof. Wyville, F.G.S. Queen's College, Belfast. 
Thomson, Thos. Esq. Hull.

Thornton, Rev. John, M.A., F.G.S., \&c. Aston Abbots, near Aylesbury.

Tite, S. C. Esq. Towcester, Northamptonshire.

Tomes, R. F. Esq. Welford, near Stratfordon-Avon.

Tomes, John, Esq. 37, Cavendish-square.

Tomkins, Chas. M.D., F.L.S., \&c. Westonsuper-Mare, Somersetshire.

Torquay Natural History Society.

Tovey, R. Esq. 9, Waterloo-place, Southampton.

Townsend, Mrs. R. E. A. Spring Field, Norwood.

Traill, Prof. Thos. Stewart, M.D. Edinburgh.

Trench, Rich. Esq. Deanery, Westminster.

Trevelyan, Sir W. C. Bart., M.A,. F.G.S., \&c. Wellington, Northumberland, and Athenæum.

Trubner, M., Esq. Paternoster-row, E.C.

Twamley, Charles, Esq. F.G.S. 6, Queen'sroad, Gloucester-gate, Regent's Park.

Tweedy, M. Esq. Alverton, Truro.

Tyler, Chas. Esq. 24, Holloway-place, Holloway.

Tylor, Alfred, Esq. F.G.S., L.S. Warwicklane, Newgate-street.

United States Military Academy, West Point, New York (per C. Layton, 16, Little Britain).

University of Glasgow.

University of Tubingen.

University Library, St. Andrew's.

University of Edinburgh.

University of Breslau (per Franz Thimm, 3, Brook-street, Grosvenor-square.)

Valenciennes, Prof. Jardin des Plantes, Paris.

Vallance, Mrs. 54, Queen-street, Brighton.

Veal, Samuel, Esq. Wolverhampton.

Verneuil, Mons. Edouard de, For. M.G.S. 57, Rue de la Madeleine, Paris.

Vetch, Captain J. R.N., F.R.S., G.S., \&c., Admiralty, Whitehall.

Vicary, Wm. Esq. St. David's-hill, Exeter.

Wade, Mrs. John, Leeds.

Walker, H. M.D. Calcutta, per Williams and Norgate.
Wall, Geo. P. Esq. Pitmoor, near Sheffield.

Waller, Edward, Esq. Finnoe House, Burrisokane, Ireland.

Walmstedt, Dr. L. P. Prof. Mineralogy, Upsala, per Trübner and Co. Paternoster-row.

Walton, William, Esq. London Dock Head, Poplar.

Walton, William, Esq. 17, Grosvenor-place, Bath.

Walwein, Mons. Paris.

Ward, N. B. Esq. F.R.S., L.S., \&c.. 14, Clapham-rise.

Ward, Henry, Esq. Wolverhampton.

Waring, Samuel Long, Esq. 115, St. Johnstreet.

Warrington Museum and Library.

Warwickshire Natural History Society.

Watson, Thos. Esq. 64, Old Broad-street.

Watts, John King, Esq. St. Ives, Huntingdon.

Wauchope, Admiral, Dacre, Penrith.

Weston, Charles H. Esq. B.A., F.G.S., 5, Sion-place, Sion-hill, Bath.

Wetherell, N. T. Esq. M.R.C.S. \&c. Highgate.

Wheldon, John, Esq. 4, Paternoster-row.

Whewell, Rev. William, B.D., F.R.S., Hon. M.R.I.A., F.S.A., F.G.S., F.R.A.S., Mast. Trin. Coll. Camb. Lodge, Cambridge.

White, Alfred, Esq. F.L.S. \&c. Castle-street, Cow-cross.

White, J. G., M.D., 26, Lloyd-square, Pentonville.

White, Rev. Wm. Farrer, St. John's Coll. Cambridge.

Wiggins, John, Esq. F.G.S. 30, Tavistockplace.

Willcock, J. W. Esq. 6, Stone-buildings, Lincoln's Inn.

Willaume, Thos. B. T. Esq. 5, Leicestergardens, Cleveland-square, Bayswater.

Williams, W. W. M.D. Gloucester.

Wills, William, Esq. Edgbaston, Birmingham.

Wilson, Rev. Dr. Southampton.

Wilson, D. Esq. 5, St. Nicholas-street, Aberdeen.

Wilson, John, Esq. F.R.S.E., F.G.S., Elm Cottage, Edinburgh.

Wilson, J. H. Esq. B.A., F.L.S., F.R.B.S. \&c. The Grange, Worth, Sussex. 
Wilson, Edward, Esq. F.G.S. \&c. Lydstip House, near Tenby, S. Wales.

Wilson, Rev. Sumner, Newnham, Winchfield.

Wilson, Edward, Esq. Lyons.

Wiltshire, Rev. Thos. M.A., F.G.S., \&c. Rectory, Bread-street-hill.

Wilton, John W. Esq. Gloucester.

Witts, Rev. E. F., F.G.S. Upper Slanglor Rectory, near Stow-on-the-Wold.

Winstone, Benjamin, M.D. 7, Ely-place, Holborn.

Wintle, G. S. Esq. East Gate-street, Gloucester.

Wolley, Rev. Charles, Eton College.

Wood, Edward, Esq. F.G.S., F.R.S.L., \&c. Richmond, Yorkshire.

Wood, Mrs. Col. Rectory House, Wickham, Bishops Witham.

Wood, S. V. Esq. F.G.S. \&c. St. Stephen's House, Twickenham, Treasurer.

Wood, Rev. Henry, Queen's Coll. Oxford.

Woodall, Capt., J. P., F.G.S., \&c. St. - Nicholas House, Scarborough.
Woodd, C. H. L. Esq. F.G.S., F.S.A. \&c. Belsinga, Hampstead.

Woodward, Charles, Esq. F.R.S. 10, Compton-terrace, Islington.

Worcestershire Nat. Hist. Soc. Foregate, Worcester.

Working Men's College, 45, Great Ormondstreet.

Wright, Chas. C. Esq. 37, Woburn-square. Wright, Thomas, M.D., F.R.S.E., G.S., Pres. of the Phil. and Lit. Institution, Cheltenham.

Wright, E. Percival, Esq. University, Dublin.

Yates, James, Esq. M.A., F.R.S., L.S., G.S. \&c. Lauderdale House, Highgate.

Yorke, Hon. Mrs. Hanescombe, Torquay.

Yorkshire Naturalists' Club, York.

Young, J. Forbes, M.D., F.L.S. \&c. Upper Kennington-lane.

Young, James, Esq. Tower-hill, East Smithfield.

Zeuschner, Prof. Cracow, per Thimm and Co. 


\section{INTRODUCTION.}

The best general account of the Chalk Formation of England will be found in the 'Geology of England and Wales,' by Conybeare and Phillips, 1822, in which is embodied a detailed description of the Chalk Cliffs in the neighbourhood of Dover by Mr. W. Phillips, published in the fifth volume of the "Transactions of the Geological Society.' The divisions of the Formation which Mr. Phillips has pointed out, are more minute than can be followed in the present Monograph, since few collectors attend to the precise part of the series from which their specimens are derived. I have, therefore, usually contented myself with referring specimens to one or other of the following great divisions of the Chalk, which are easily recognised, although they are not separated by any well-defined lines.

1. Upper Chalk; my specimens of which are principally from Norfolk, or from Gravesend and Northfleet: this division is rich in Organic Remains.

2. Middle Chalk, which contains but few Fossils: those examined are mostly from Kent, Surrey, Sussex, and the Isle of Wight.

3. Lower or Grey Chalk, containing numerous Fossils, especially Ammonites and Turrilites: the neighbourhood of Dover, and of Lewes, and the Isle of Wight furnish large supplies; many specimens have also been procured from the numerous Chalk-pits along the foot of the North Downs, and others have been obligingly sent from Devizes, by Mr. W. Cunnington.

4. The "Chloritic Marl" of the Isle of Wight, a bed of some six or eight feet thick at the base of the Chalk, is very rich in Organic Remains, with which I have been most liberally supplied from the rich Collection of Mr. S. Saxby, Jun., of Bonchurch. The "Chalk with Siliceous Grains," of Somersetshire, is probably on the same parallel as the "Chloritic Marl," and also contains abundance of Shells, of which a large collection formed at Chardstock has been most obligingly lent me by Mr. J. Wiest: these have the advantage of being far better preserved than is usual with the Chalk Fossils. I have also had the use of Collections from this bed, belonging to Mr. E. H. Bunbury and Mr. Morris. 
Besides the gentlemen already mentioned, I am indebted for the loan of specimens to Mr. Baber, Mr. Bowerbank, Mr. Henry Catt, Mr. Faulkner, Mr. Flower, Mr. Hudson, Mr. J. G. Low, Mr. S. J. Mackie, Dr. Mantell, Mr. H. Taylor, and Mr. Wetherell, whose names will be frequently mentioned in the course of the work, together with those of others, who may be kind enough to lend me similar assistance. I have also to thank Mr. Morris most especially for his valuable assistance in determining many obscure species, and Mr. S. P. Woodward, for notes relating to specimens in the British Museum, and for many drawings of parts requiring particular accuracy.

In giving the generic characters of Fossil Shells, it seems unnecessary to add descriptions of the Animals supposed to have inhabited and formed them; since such descriptions must be more or less conjectural, and information on this head is amply and more fitly provided by writers on the recent branches of Natural History. The Palæontologist must be contented with descriptions of the shell only, such as were furnished by the earlier school of Conchologists. The student who desires information about the Molluscous inhabitants of recent Shells, should consult the 'History of British Mollusca and their Shells,' by Forbes and Hanley, and the 'Figures of Molluscous Animals' by Mrs. Gray, or he will find in the 'Rudimentary Treatise of Recent and Fossil Shells' by S. P. Woodward a large amount of information condensed into a small and most economical form. 


\section{FOSSIL REMAINS OF MOLLUSCA \\ FOUND IN THE CHALK.}

\section{CEPHALOPODA.}

\section{Belemnites, Auctorum.}

Animal unknown, enclosing a straight elongated conical, or fusiform calcareous shell or guard more or less pointed below, and pierced above with a conical cavity or alveolus, in which is lodged the phragmacone, a hollow horny cone divided into chambers by nearly horizontal septa, which are traversed on the anterior or ventral margin by a siphuncle. Wall of the alveolus entire. Exterior of the shell marked, in many species, by a furrow down the front, and one down the middle of each side, but without any branching vascular impressions.

The above description includes all the parts of the Belemnites which have been found in the Chalk; but in some of the beds of the Oolitic series more perfect specimens are found, in which the phragmacone is produced far above the walls of the calcareous shell, and is provided with two elongated, slender, testaceous processes, proceeding from the dorso-lateral margins of its upper edge; and the whole body is invested with a thin testaceous or corneo-calcareous integument. For full descriptions of these interesting remains the reader is referred to the Memoirs of Professor Owen in the 'Philosophical Transactions of 1844,' and of Dr. Mantell in the volumes of the same work for 1848 and 1850 , and to the 'Paléontologie Française, Terrains Jurassiques' of M. D'Orbigny.

M. D'Orbigny separated from the Belemnites those species which have a fissure down the anterior or ventral side of the alveolar cavity, and which are provided with two longitudinal depressions down the dorso-lateral portions of the shell, from which, in some species, proceed branching vascular impressions; to these he has given the name of Belemnitella.

\section{Belemnitzs olitimus, $D^{\prime}$ Orb. Plate $\mathrm{I}$, fig. 17 .}

Belemnites manimus, in part? Lister. Hist. Anim. Angliæ, tab. vii, fig. 32 ?

- Listeri, Phillips. Geology of Yorkshire, vol. i, tab. i, fig. 18?

- ultimus, D’Orbigny. Paléont. Franç. Terr. Cret., Supp., p. 24. 
B. Testâ sub-cylindricá, infernè rotundatâ, acuminatâ ; supernè rotundato-quadratá ; anticè, lateraliterque lineá impressá leviter notatá.

Shell sub-cylindrical, slightly flattened both on the front and sides of the upper part, rounded below, and tapering gradually to a blunt point; with a slight furrow down the upper part in front, and a slight furrow down the upper part of the middle of each side; opening oval.

Length, 2 inches; greatest breadth, $\frac{2}{10}$ ths of an inch.

Found by Mr. Saxby, in the Chloritic Marl of Bonchurch, in the Isle of Wight; found also in the Red Chalk of Yorkshire, and in the Gault of Folkstone.

This species is usually confounded with Belemnites minimus of the Gault, from which it is to be distinguished by a more cylindrical form, the slightly squared oval opening, and shortness of its lateral furrows. B. minimus on the contrary is spindle-shaped, with a round opening, and a double line impressed on each side, which reaches nearly to the point.

Professor Phillips first pointed out the necessity of separating the two species (' Geol. Yorksh.,' vol. i, p. 46), and called this one B. Listeri, although that name had previously been applied by Dr. Mantell to the other species. Lister undoubtedly had the two species before him when he wrote; but his name having been since restricted by all authors to the common Gault species, which has been called indiscriminately $B$. minimus and $B$. Listeri, it would increase the confusion to apply either of those names to this species, which may therefore pass under M. D'Orbigny's name of $B$. ultimus.

Plate I, fig. 17, $a, b, c$. Three views of Mr. Saxby's specimen, from the Chloritic Marl of Bonchurch : the point having been worn away, its outline is restored from another specimen.

\section{Beleminitella, D'Orbigny.}

Animal unknown, enclosing a straight, elongated, conical, or fusiform calcareous shell or guard, more or less pointed below, and pierced above with a conical cavity or alveolus, in which is lodged the phragmacone, a hollow horny cone, divided into chambers by nearly horizontal septa, which are perforated on the anterior or ventral margin by a siphuncle. Wall of the alveolus divided on the anterior side by a perpendicular slit, which remains open above, but is gradually closed below, where its place is marked by a groove on the outside of the shell, and a corresponding groove on the inside of the alveolus. Back of the exterior of the shell marked by two longitudinal depressions, which in some species are connected with complicated vascular impressions.

The remains of Belemnitella hitherto found in the Chalk, in this country, are limited to the calcareous shell; in addition to which portions of the phragmacone are preserved in the specimens of $B$. mucronata found in the Cretaceous Sandstone of Maestricht and Ciply. 
The genus Belemnitella was separated from Belemites by M. D’Orbigny, on account of the slit down the front of the alveolus, and the vascular impressions on the back and sides of the shell, which are wanting in Belemnites; the latter character is most strongly developed in B. mucronata and B. quadrata, and but faintly seen in B. lanceolata and $B$. plena. These characters seem a slight foundation for a separate genus; but the division has been generally adopted. All the Belemnitellæ, yet known, belong to the Chalk.

The Belemnitellæ may be divided into two sections, depending on the form and lining of the alveolar cavity : in $B$. mucronata and $B$. lanceolata the alveolus is a regular cone, with a rounded base, of which the apex forms an angle of about 20 degrees; the cavity is lined by a smooth continuous shelly layer, which in the fossils is denser, and less crystalline than the rest of the shell; this cavity is filled by the phragmacone, and is slightly marked by the edges of the septa.

In $B$. quadrata the lower part of the cavity for about one third of an inch is in the form of a cone, with a round base, of which the apex has an angle of about $20^{\circ}$; this is lined with a smooth shelly layer, and was evidently destined to receive the phragmacone. The cavity then widens out suddenly, and becomes nearly square; this upper angular part has no special lining, but is rough, with irregular rings marking the growth of the shell; the anterior slit reaches a little way into the lower part of the cavity. It has been suggested, that the upper angular part of the cavity may be due to decay; but its form is too constant and regular to be so explained.

The Swedish species B. subventricosa of Wahlenberg (B. mamillatus, Nills., B. scanice, Blainv.) has a cavity of analogous form to $B$. quadrata, with an irregularly triangular aperture above. M. König figured this species under the name of Paxillus belemnoideus (Icones, No. 218), apparently regarding its peculiar form of cavity as a sufficient generic character. But, as at present, we do not know the form of the phragmacone of either of these species, we cannot estimate the importance of the difference in the form of the cavity.

The vascular impressions are very differently developed in the different species of Belemnitella; they all have two depressions which extend down the sides of the posterior part; at the edge of the cavity these depressions are nearly as broad as the space between them, they diverge slightly and become narrower in their course downwards, and terminate near the apex of the shell, almost as near to the anterior as to the posterior side. These two depressions are usually all that we see of the vascular markings on $B$. lanceolata and $B$. plena, and on worn specimens of the other species; but on well-preserved specimens of $B$. musronata and $B$. quadrata they are bounded on each side by an impressed line, from which spread off a number of branches, dividing and subdividing with great complication, which cover the sides and front of the shell.

Casts of the alveolar cavity of Belemnitellæ are frequently found in the flint of the Upper Chalk, which sometimes show more clearly the form of the cavity than can be scen in the shells themselves; the two woodcuts $\mathrm{A}$ and в are copied with Dr. Mantell's permission, from the second edition of his 'Geological Excursions round the Isle of Wight,' p. 440; 
the specimen they represent was found in the Chalk near Ventnor, and is in the Cabinet of Mr. S. H. Beckles. Fig. B shows the upper part of one side of the phragmacone apparently complete; the upper transverse lines are too sinuous to represent the edges of the septa, which, as far as we know them, are nearly horizontal. Perhaps, the lower parallel and nearly horizontal lines may mark the edges of the septa, and the upper waving lines may indicate the growth of the margin of the phragmacone, which seems to have been furnished with two lateral processes.

In fig. $\mathbf{A}$, the cast displays very clearly the complicated groove running down the back of the alveolar cavity.

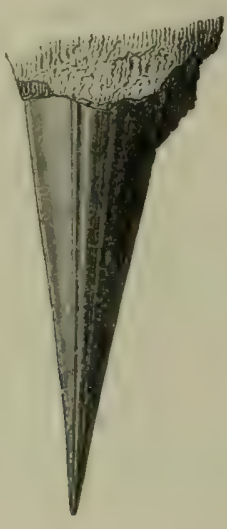

Fig. A

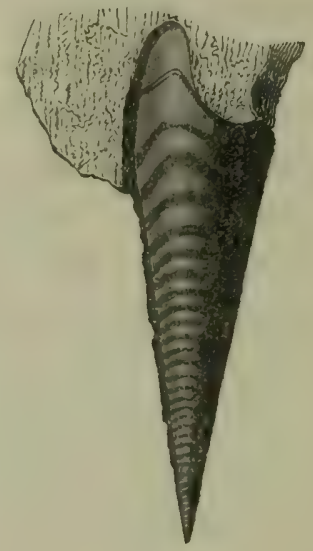

Fig. B

1. Belemnitella mucronata, Schlotheim, Sp. Plate I, figs. 1, 2, and 3.

Belemnites, $1^{\sigma}$ species : Breyn, De Belemnitis, figs. $1-6$.

Belemnites mucronatus, Schlotheim. Petref., p. 47, No. 4.

- $\quad$ - Mantell. Sussex, t. xvi, fig. 1.

- $\quad$ - Nilsson. Petrif. Suec., t. ii, fig. 1.

- _ - Sowerby. Min. Conch., t. 600, figs. 2 and 4.

Beleminteses electrinus, Miller. Geol. Tr., 2d series, vol. ii, t. viii, figs. 18-21.

Actinocamax verus? Miller. Loc. cit., t. ix, figs. 17 and 18.

Beleminitella mucronata, D’Orbigny. Palæont. Franç. Terr. Crét., t. vii.

Geol. of Russia and the Ural Mountains, vol. ii, t. xliii, figs. 1 and 4 , not figs. 2 and 3.

B. Testâ subcylindricâ, impressionibus duabus vascularibus ramosis notatâ, anticè fissuratấ, posticè obtusấ mucronatâ ; aperturâ subrotundấ; alveolo conico excentrico.

Shell elongated, subcylindrical, widening very slightly above, obtuse below, with a distinct rounded point. Opening circular. Alveolus forming a regular hollow cone, with a round base, and an apex of $18^{\circ}$ to $20^{\circ}$, which is considerably nearer to the anterior than to the posterior side of the shell; the position of the septa may be faintly traced on the lining of the alveolus. The fissure extends to within half an inch of the apex of the cavity, but may be traced to the bottom, on the inside, by a continued depression; another 
impressed line runs down the dorsal side of the cavity. The vascular impressions are usually well-marked, and cover a large part of the surface, they branch off from a pair of double lines, which commence near together on the two sides of the back, and separate gradually as they extend downwards to near the point.

$B$. mucronata is nearly allied to $B$. lanceolata; it may be recognised by a more cylindrical form with a distinct mucro, by its well-marked vascular impressions, and by the eccentricity of the alveolar cavity.

In a fine specimen from Norwich, measuring $3 \frac{1}{2}$ inches in length, the greatest diameter is $\frac{5}{8}$ ths of an inch, and the fissure extends externally $\frac{3}{4}$ ths of an inch. But all the specimens found in this country are broken off at the top, where the walls of the alveolus are very thin. They are found in the Maestrict Sandstone with the upper part much better preserved, the whole being 6 inches long, the alveolus spreading out at top to a width of above an inch, and with an external fissure $2 \frac{1}{2}$ inches long.

Found everywhere in the Upper Chalk of the South of England, and particularly abundant in Norfolk. It is also found in the Upper Chalk of France, Germany, Belgium, Sweden, and Russia. Also in the Cretaceous Sands of Maestrict and Ciply near Mons, and at Faxoe in Denmark.

2. Belemnitelda lanceolata, Schlotheim, Sp. Plate I, figs, 4-6.

Belemnites, $2^{a}$ species : Breyn, De Belemnitis, figs. 7-10.

- Ianceolatus, Schlotheim. Petrefactenkunde, p. 49, No. 8.

- Mucronatus, Brong. and Cuvier, t. iii, fig. 1 ?

- $\quad$ - Blainville. Belemnites, t. i, fig. 12.

- - Sowerby. Min. Conch., t. 600 , fig. 1, excluding all the other figures.

- _ - Woodward. Geol, Norfolk, p. 49.

Belemnitella mecronata, var. Fusiforme, D'Orbigny. Geol. of Russia and the Ural Mountains, vol. ii, t. xliii, figs. 2 and 3.

B. Testâ elongatâ, fusiformi; anticè subdilatatâ, fissuratâ; posticè acuminatâ; aperturâ subrotundâ; alveolo conico, centrali.

Shell elongated, fusiform, widening at the opening, then somewhat contracted, and again enlarging to about two thirds its length, whence it gradually tapers off to a point. Alveolus slightly oval above, circular below, forming a regular hollow cone, of which the apex with an angle of $20^{\circ}$ is nearly on the central axis of the shell; the alveolar cavity is lined by a distinct shelly layer, faintly marked by numerous horizontal rings, very near each other in the lower part, and becoming gradually more distant upwards, and is slit down its anterior side by a fissure which extends within nearly to the apex of the cavity; but is partially closed on the outside by the new layers of shell, which in old specimens cover about half an inch of the lower part of the original fissure. Another 
impressed line runs down the back of the alveolar cavity. Vascular impressions apparently resembling those of $B$. mucronata are faintly marked and frequently obliterated.

This Belemnite, which was well distinguished by the earlier writers on the subject, has been confounded by all later authors with $B$. mucronata, from which it is distinguished externally, by its less cylindrical form, and fainter vascular impressions; and internally, by the central position, and more circular section of the alveolus.

Breyn, one of the earliest writers who made an approach towards the true nature of Belemnites, distinguished the present species from B. mucronata without naming either, and has given good figures of both, as Species 1 and 2. He was followed by Schlotheim, who, referring to Breyn's figures, names his 1st species $B$. mucronatus, and his $2 \mathrm{~d}$ species $B$. lanceolatus, which names we must adopt, on the principle of priority; an unlucky remark of Schlotheim that, perhaps, Montfort's Hibolithus hastatus might prove a variety of his B. lanceolatus, has led both D'Orbigny and Bronn to throw aside Schlotheim's name $B$. lanceolatus, as a synonym of B. hastatus; the slightest reference to Breyn would have saved them from this error, as that author's $2 d$ species belongs clearly to the Genus Belemnitella, the slit down the front of the alveolar cavity being well shown in the figures, and clearly described in the text.

Miller was probably aware of the difference between the two species, since finding this one figured by Blainville as $B$. mucronatus, he gave to the original $B$. mucronatus the new name of $B$. electrinus. Woodward living in Norfolk, where the two species are abundant, was well acquainted with both, and distinguishes them clearly in his Catalogue, as $B$. mucronatus tapering off to a point, and $B$. electrinus obtuse, with a mammillated point.

Sowerby, Min. Con., t. 600, threw the two species together, figuring them both under the name of $B$. mucronatus, and the same is done by M. D'Orbigny, in the second volume of the 'Geol. of Russia, where they are well figured as Belemnitella mucronata, variété fusiforme and variéte renflée; but in the 'Paléontologie Française' we have only the true B. mucronata, well figured and described, without any allusion to the other form.

\section{Belemnitella quadrata, Defrance, Sp. Plate I, figs. 7-11.}

Belemnites quadratus, Blainville. Belemnites, t. i, fig. 9.

- Granulatus, Sowerby. Min. Conch., t. 600, figs. 3 and 5.

Belemon pustulatum, Koenig. Icones Foss. Sect., No. 216.

Belemnitelua quadrata, D'Orbigny. Paléont. Franç. Terr. Crét., t. vi, figs. 5-10.

B. testâ subcylindricá, granulatâ ; apice obtusiusculo mucronato ; aperturâ subquadratá: alveolo infernè rotundato conico, supernè expanso subquadrato.

Shell nearly cylindrical, rounded towards the apex, which ends in a distinct point; alveolus wide, and four-sided above; round and conical below, with a short slit on the anterior side, which reaches into the rounded part of the cavity; surface almost entirely 
covered with small granulations; vascular impressions strongly marked in the young shell, but somewhat concealed by the granulations in the full-grown shell.

The external form of $B$. quadrata is nearly the same as that of some varieties of B. mucronata; so that worn specimens which have lost both their outer surface and the upper part of the alveolus may easily be confounded; and there has been confusion in consequence in the synonyms. But it is well distinguished both by the granulations of the surface and the square opening.

The lower part of the alveolar cavity, lined with a distinct, smooth, shelly layer, is of the form of a rounded cone, about a quarter of an inch deep; above this, the cavity suddenly widens out, and changes its character; it is irregularly four-sided, and the surface has no special lining, but is roughened by the rings of growth of the shell. The fissure is shallow, and reaches to the top of the lower division of the cavity. Unfortunately, the Phragmacone of this species is not known; it would probably correspond in form with the lower part of the cavity only.

Length, $2 \frac{1}{2}$ inches; greatest breadth, $\frac{4}{10}$ ths of an inch; cavity, $\frac{3}{3}$ ths of an inch, of which the broader part occupies $\frac{1}{8}$ th, and the narrow rounded cone, $\frac{1}{4}$ th of an inch.

$B$. quadrata is found in the middle beds of the chalk of the counties of Kent, Surrey, and Sussex, but is no where a common species. It has also been found in the upper chalk of Northfleet.

It occurs, according to M. D'Orbigny, in the white chalk of Rheims in France, and of Visé in Belgium.

4. Belemnitella plena, Blainv., Sp. Plate I, figs. 12-16.

Breyn. De Belemnitis, fig. 15?

Belemnites plends, Blainville. Belemnites, t. i, fig. 6 .

- Laxceolatus, Sowerby. Min. Conch., t. 600, figs. 8 and 9.

Geinitz. Quadersansteingebirge, t. vi, figs. $3-5$.

Belemnitella vera, D’ Orbigny. Paléont. Franç. Terr. Crét., Suppt, t. ii.

B. testâ elongatâ fusiformi, sublavi, supernè rotundato-trigonâ canaliculatü, medio rotundatâ dilatatâ; apice acuminato.

Shell elongated; when young cylindrical, with a tapering point; when full-grown fusiform, swelling out below the middle, and tapering below to a point; front marked with a slight furrow; a broad longitudinal depression on each side of the back, giving somewhat of a three-sided form to the upper part of the shell. All the specimens have the walls of the alveolar cavity broken off, leaving usually a projecting conical end, in the centre of which the point of the alveolus may be distinguished.

The specimen, fig. 12, belonging to Mr. Morris, has fortunately the lower part of the cavity preserved, but not enough to show any trace of a fissure; therefore the supposed fissure figured by M. D'Orbigny, pl. ii, figs. 2, 4, and 7, in a more truncated specimen, 
must be due to decay. Geinitz has figured the lower portion of the Phragmacone, but his figure is hardly intelligible.

Although the specimens of this Belemnite are found truncated at different attitudes, and the fracture is either nearly flat or more or less conical, there are common characters in the broken ends of all, which are without doubt connected with the manner of growth of the shell. There are usually two more prominent ridges on each side, and three slighter ridges on the back. The sides of the angular cone thus formed, appear to have some analogy with the angular opening of $B$. quadrata, and render it probable that $B$. lanceolata will be found to belong to the same division of the genus as that species.

M. D'Orbigny has named this species $B$. vera, on the supposition that it is the Actinocamax verus of Miller; but the description given by that author proves that, as Mr. Sowerby correctly observed in the 'Mineral Conchology,' A. verus is a worn specimen of B. mucronata. Miller describes his species as having "two longitudinal, towards the apex branching, impressions of blood-vessels." He also states that it is often found in flints. Both the description and the placing in it in the chalk with flints are decisive against regarding it as $B$. lanceolatu. Every species of Belemnite, when rolled and worn at the top, may present a form similar to that of Miller's figure 17; and the B. mucronata especially, in decaying peels off in concentric layers, as in his figures 11,12 , and 13 , 'Geological Transactions,' 2d series, vol. ii, pl. 9. It is probable that when describing Articonamax verus, Miller may have had before him worn specimens of several species of Belemnite. Such names founded on misconception had better be allowed to drop. But in this instance, as Miller's description applies to $B$. mucronata, there is no room for his name of $A$. verus. The name first in point of priority is $B$. plenus of Blainville, which has consequently been adopted. Sowerby's name, $B$. lanceolatus, is not only posterior to Blainville, but had been previously applied by Schlotheim to another species.

Length, $3 \frac{1}{2}$ inches; greatest breadth, $\frac{5}{8}$ ths of an inch.

Common throughout the grey chalk of the South of England, and found in the lower beds of the chalk in Belgium, Germany, and the North of France.

\section{Nautilus, Linn.}

Shell discoidal, spiral, chambered, compressed or ventricose, with contiguous whorls regularly convoluted on the same plane, the last partially or entirely concealing the previous whorl; chambers separated by transverse, concave septa, with simple sinuous margins, and traversed near their centre by a continuous siphuncle; the last chamber large, and capable of containing the animal. 
1. Nattilus levigatus, $D^{\prime} O r b$. Plate II, figs. 1 and 2.

Nautilus lefvigatus, D’Orbigny. Paléont. Franç. Terr. Crét., pl. xvii.

N. testá globosâ, lavi, umbilico minimo aut nullo; aperturấ semi-circulari; septis parum arcuatis; siphunculo subcentrali.

Shell globose, smooth, with the back and sides uniformly rounded, and a very faint line running along the middle of the back; umbilicus very small and entirely concealed in the inner whorls; septa slightly arched, with nearly straight margins; siphuncle a little in front of the centre; mouth nearly semi-circular, but rather wider than high, deeply indented by the preceding whorl, with a broad shallow mesial sinus.

This shell attains a large size. A specimen from Brighton measures $4 \frac{1}{2}$ inches in diameter and $3 \frac{1}{2}$ inches in breadth.

$N$. lavigatus is one of the commonest of the cretaceous species, and is found throughout the whole range of the Chalk, viz., in the Upper Chalk near Brighton ; in the Middle Chalk near Maidstone, Hemel Hempstead, and Tring; in the Grey Chalk at Dover and Lewes; in the Chloritic Marl of Bonchurch in the Isle of Wight; and in the Chalk with siliceous grains at Chardstock and on the coast of Dorsetshire. It is found in France in the Upper Green Sand, the Lower and Middle Chalk.

The only cretaceous species of Nautilus for which this could be mistaken, are $N$. Bouchardianus, D'Orb. and $N$. simplex, Sow. ( $N$. Clementinus? D'Orb.) both of which have a more marked umbilicus, and a depression on the ventral margin of the septa; the latter is also a less globose shell, and has the siphuncle nearer the ventral than the dorsal margin.

\section{Nautruụs expansus, Sow. Plate II, figs. 3-5.}

Nautilus expansus, Sowerby. Min. Conch., t. 458, fig. 1.

- Archiaciands, D'Orbigny. Paléont. Franç. Terr. Crét., t. xxi.

$N$ testâ inflatâ, lateraliter compressiusculâ, umbilicatâ, subtiliter striatấ; umbilico sub-carinato; aperturâ latâ sub-pentagonâ;; septis undulatis; siphunculo sub-centrali.

Shell globose, with sloping slightly flattened sides and a sharply defined umbilicus; surface elegantly marked by fine sharp lines of growth, which are deeply incurved in front; whorls increasing rapidly in size and nearly concealing the preceding whorls; septa very flexuous; siphuncle within the centre of the septum; mouth about as broad as high, somewhat pentangular, rounded in front, with nearly straight sloping sides deeply indented by the inner whorl, and with a deep, broad, rounded sinus.

Diameter $2 \frac{1}{4}$ inches, breadth $1 \frac{1}{2}$ inch.

N. expansus is confined to the lowest bed of the Chalk; it is rare in the Chalk Marl of Hamsey near Lewes, and in the Chloritic Marl of Bonchurch in the Isle of Wight; and 
abundant in the Chalk with siliceous grains at Chaldon and Man-of-War Cove in Dorsetshire, and Chardstock in Somersetshire. M. D'Orbigny cites it from the Craie Chloritée of Mount Ste. Catherine, near Rouen.

The figure in the 'Mineral Conchology' is taken from a specimen somewhat expanded at the mouth by pressure; but the form of the umbilicus and the fine sharp striæ leave no doubt of its identity with $N$. Archiacianus, D'Orb.

3. Nadtilus Desiongchampsiands, D’ Orb. Plate III, figs. 1 and 2.

NaUtilus elegans, part. Mantell. Fossils of the South Downs, t. xxi, fig. 8.

- Deslongchampsianus, D’ Orbigny. Paléont. Franç. Terr. Crét., t. xx.

N. testâ sub-globosâ, umbilicatâ, transversim costatâ et longitudinaliter striatâa; umbilico carinato; costis elatis flexuosis; striis tenuibus decussatis; aperturâ semi-ovali.

Shell sub-globose, umbilicated, elegantly ornamented with sharp elevated transverse flexuous ribs, which are usually crossed by thin longitudinal lines; the latter are often obliterated in ill-preserved casts; the ribs rise within the umbilicus and are bent at a sharp angle over its carinated margin ; they then sweep forward in a bold curve, and form a deep sinus on the back, where they occasionally divide into two; the ribs are steep on their front side and sloping behind, thus forming a series of steps on the surface; the edge of the umbilicus is angular or raised into a slight keel.

The longitudinal lines are very prominent in some specimens, but can hardly be discerned in others; but the species can always be distinguished by the form of the ribs, the deep and angular umbilicus. It is common in the Grey Chalk of Lewes, Dover, the Isle of Wight, \&c., and in the Chalk with siliceous grains of Chardstock, Somersetshire. In France it abounds in the Craie Chloritée of Mount Ste. Catherine, near Rouen.

Diameter $2 \frac{1}{2}$ inches, breadth $1 \frac{3}{4}$ inch.

4. Nadtilus elegans, Sowerby. Plate III, fig. 3 ; and Plate IV, fig. 1.

Nattilus elegans. Sowerby. Min. Con., t. 116.

- - Mantell. Fossils of the South Downs, t. xx, fig. 1.

- - D Orbigny. Paléont. Franç. Terr. Crét., t. xix.

N. testa globosâ, costatâ; costis aqualibus, rotundatis, sub-flexuosis; aperturâ semicirculari; siphunculo inter dorsum et septi centrum posito; umbilico minimo.

Shell globose, uniformly rounded, ribbed; umbilicus slightly marked on the outer but entirely concealed in the inner whorls; ribs equal, rounded, and regular, bending in a simple curve from the umbilicus to the back, where they form a broad shallow sinus; aperture semi-oval, a little higher than broad, deeply indented by the preceding whorl. Siphuncle placed about half way between the centre of the septum and the back. 
Diameter $6 \frac{1}{2}$ inches, breadth 5 inches. A gigantic specimen, sent me by Mr. Tyler from Hamsey near Lewes, reaches $11 \frac{1}{2}$ inches in its greatest diameter, and the ribbing continues of about the same breadth throughout. 'This species is common in the Grey Chalk of the South of England and in the lower beds of the Chalk of France.

For many years all the ribbed Nautili found in the Chalk were confounded together under the name of $N$. elegans. Sowerby separated $N$. radiatus. But we owe to $M$. D'Orbigny the clear distinction of the different species, which may be known as follows :

$N$. elegans is the most globose shell of the group, and has the smallest umbilicus; it is also to be known by the position of the siphuncle between the back and the centre of the septum.

$N$. pseudo-elegans is rather less globose than the preceding, has a more distinct umbilicus, broader and fewer ribs, and the siphuncle between the ventral margin and the centre of the septum; the two species are so much alike that the only character to be relied on for distinguishing them is the position of the siphuncle.

$N$. radiatus is easily recognised by a flatter form, with sloping sides, large umbilicus and deep septa with a sinuous margin; the siphuncle occupies nearly the same position as in the last; but there is also a marked depression of the septum close to the ventral margin, which is not found in either $N$. elegans or pseudo-elegans.

$N$. Neocomiensis has flat and nearly parallel sides, a very large umbilicus, the ribs much bent on the back, the siphuncle between the centre and the ventral margin, but without the ventral depression of the septum.

$N$. Deslongchampsianus is easily distinguished by the cross longitudinal ribs, and even if these are lost, by the elevated edge of the umbilicus.

In all these species the ribbing is only seen in the exposed portion of the outer whorl, being concealed within by a layer of shell formed by the ventral fold of the mantle. Thus specimens which have lost the outer whorl may appear partially or entirely smooth.

5. Nautilus pseddo-elegans, D’Orb. Plate IV, fig. 2.

Nautilus pseddo-elegans, D'Orbigny. Paléont. Franç. Terr. Crét., to viii and ix.

N. Testâ ovatâ, subcompressá, costatâ, umbilicatâ; costis aqualibus, rotundatis, flexuosis; umbilico parvo; aperturâ semi-ovali; septis arcuatis; siphunculo inter ventrem et septi centrum posito.

Shell ovate, ribbed, with a small well-marked umbilicus; ribs broad, rounded, and flexuous, with a deep sinus on the back; aperture semi-oval, higher than broad, deeply indented by the preceding whorl; septa arched, with the siphuncle betwcen the centre and the ventral margin.

Diameter 7 inches, breadth 4 inches.

Common in the Grey Chalk of Lewes and elsewhere. Professor E. Forbes appears to 
have seen specimens from the Lower Green Sand,* to which Formation M. D’Orbigny states that it is confined in France.

M. D'Orbigny separated this species from $N$. elegans, which it closely resembles; it is less globose, has broader and more flexuous ribs, deeper septa, and a more distinct umbilicus; but it is best distinguished by the position of the siphuncle, which in this species is situated between the inner margin and the centre of the septum, and in $N$. elegans is nearer to the back. Notwithstanding this character, most writers seem disposed to throw them together.

6. Nautilus radiatus, Sow. Plate V, figs. 1 and 2.

Nautilus radiatus, Sowerby. Min. Conch., t. 356.

D'Orbigny. Paléont. Franç. Terr. Cret., t. xiv.

N. Testâ ovatâ, subcompressấ, costatâ, latè umbilicatâ; costis latis, aquralibus, flexuosis; septis arcuatis, margine flexuosis, ad ventrem depressis; siphunculo inter ventrem et septorum centrum posito.

Shell gibbose, with sloping flattish sides and rounded hack, ornamented with broad flexuous equal ribs; septa, with a flexuous margin low at the sides and produced at the back, marked with a deep depression close to the edge of the preceding whorl; siphuncle between the centre and the ventral margin; aperture semi-oval, cousiderably higher than broad, slightly indented by the preceding whorl; umbilicus large, exposing all the inner whorls. $\dagger$

Diameter 7 inches, breadth 4 inches.

Common in the Chalk with siliceous grains at Chardstock in Somersetshire, and also found in the Grey Chalk near Dover, Guildford, \&c. In Professor Forbes's 'List of Lower Green Sand Fossils' it is mentioned as found at Atherfield and Sandgate, and M. D'Orbigny quotes it in France from the Lower Chalk, the Upper and Lower Green Sands.

$N$. radiatus is easily distinguished from $N$. pseudo-elegans by its large umbilicus, the flexuous margin, and the ventral depression of the septa; the latter character separates it also from $N$. Neocomiensis.

* Journal of Geol. Society, vol. i, p. 353.

† The ribs begin to show themselves when the shell is about one inch in diameter; previously, it is ornamented with fine sharp elevated lines marking the growth of the shell, crossed by finer longitudinal lines, as seen in fig. 2 ; a similar ornament is found in many species of Nautilus when young. 


\title{
7. Nautilus Neocomiensis, D’Orb. Plate V, fig. 3.
}

\author{
Nautilus Neocomiensis, D’ Orbigny. Paléont. Franç. Terr. Crét., t. xi.
}

N. Testâ inflatâ, lateraliter compressâ, latè umbilicatấ, costatâ; costis latis flexuosis, dorso sub-angulatis; septis margine paulum flexuosis; siphunculo inter ventrem et septorum centrum posito.

Shell gibbous, with flattened sides and a broad umbilicus, ornamented with rounded flexuous ribs, which are less marked at the sides but broad and large on the back, where they bend so rapidly as to form an almost angular sinus; the sides of the whorls being nearly parallel, and the whorls increasing but slowly in breadth, the whole shell has it flattened form by which it is easily recognised; margins of the septa slightly curved; siphuncle half-way between the centre and the inner margin of the septa.

We have only seen one small specimen from the Grey Chalk, which we can refer to this species; it is from Urchfont near Devizes, in the Collection of Mr. Cunnington, and is 2 inches in its greatest diameter and $1 \frac{1}{4}$ inch in breadth; although a good deal broken, it shows all the peculiar characters of the species. This species is more common in the Lower Green Sand of Dorking, Atherfield, Sandgate, \&c., where it sometimes reaches above 7 inches in diameter. M. D'Orbigny quotes it as common in the lower beds of the Middle Division of the Neocomian Formation in France.

The only species with which this can be confounded is $N$. radiatus, from which it may be known by its flatter form, larger umbilicus, septa less flexuous and without any depression at the ventral margin, and the more angular sinus of the ribs on the back.

\section{Nautilus undulatus, Sow. Plate V, fig. 4.}

\section{Nautilus undulatus, Sowerby. Mineral Conchology, t. xl.}

N. Testâ gibbosâ; juniore lavi, lateribus sub-compressis, dorso lato-rotundato; adultú lateraliter expansâ, transversim undulato-costatâ; septorum margine flexuoso; siphunculo sub-ventrali; aperturá semi-ovali; umbilico clauso.

Shell when young, smooth and regular, with flattish sides, a broad rounded back, and semi-oval aperture; when about two inches in diameter, it enlarges rapidly, expands at the sides, and begins to undulate over the back; when adult, the whole shell is ribbed in broad, coarse undulations, which are deepest on the back, but ill-defined on the sides; back marked by a line at first slightly raised, which in the old shell forms a ridge between the undulations; umbilicus covered; septa flexuous; siphuncle near the ventral margin.

We have only seen one specimen of this species from the Chalk, which was found by Mr. Wiest in the Chalk with siliceous grains of Chardstock; it is a young shell, 
$2 \frac{1}{2}$ inches in diameter and $1 \frac{1}{2}$ inch broad at the mouth; it is interesting, as it shows the change from the neatness of the young shell to the coarse irregular wavy form of the adult.

This shell is found more plentifully in the upper"part of the Lower Green Sand, where it reaches a diameter of 4 or 5 inches. M. D'Orbigny has not met with it in France.

When young, $N$. undulatus has considerable resemblance to $N$. largilliertianus, from which it is distinguished by its closed umbilicus; in its undulated stage it cannot be confounded with any other species.

9. Nautilus largilliertianus, D'Orb. Plate VI, figs. 1 and 2.

Nautilus targiluiertiands, D’ Orbigny. Paléont. Franç. Terr. Crét., t. xviii.

N. Testâ discoideâ, compressâ, umbilicatâ, delicatim striatâ; lateribus complanatis; dorso planiusculo, in medio lineato; umbilico magno, margine declivi; aperturâ ovatorhomboideä; septorum marginibus flexuosissimus; siphunculo sub-ventrali.

Shell discoidal, with fine lines of growth which are not seen in the cast; with flat sides and a somewhat flattened back, marked with a slightly raised mesial line; umbilicus large, with perpendicular sides, exposing all the inner whorls; aperture rhomboidal with rounded corners, deeply indented by the preceding whorl; margin of the septa very flexuous; siphuncle very near to the inner margin. In old shells the back is slightly undulated.

Diameter 2 inches, breadth $\frac{7}{8}$ ths of an inch.

This elegant shell is easily distinguished from the other Cretaceous species by the rhomboidal form of the whorls, well-defined umbilicus, and flexuous septa; the striæ are only seen in very well-preserved specimens.

Found occasionally in the Grey Chalk at Lewes, and in the Chloritic Marl of the Isle of Wight; more common in the Chalk with siliceous grains of Chardstock and Chaldon.

M. D'Orbigny cites it as common in the Lower Chalk of the North of France.

10. Nattilus fleuriausianus, $D^{\prime}$ Orb. Plate VI, fig. 3.

Nadtilus fledriadsiands, D'Orbigny. Paléont. Franç. Terr. Crét., t. xv.

Nadtulus Sowerbyands? D'Orbigny. Ibid., to xvi.

N. Testâ lateribus compressâ, dorso rotundatâ, sub-umbilicatâ, lavi; aperturá semiovatâ; septorum marginibus flexuosis; umbilico minimo; siphunculo sub-centrali.

Shell with sloping and somewhat flattened sides and rounded back, smooth, with a very small umbilicus; mouth semi-oval, higher than wide, deeply indented by the pre- 
ceding whorl; margin of the septa flexuous; siphuncle sub-central, but rather nearer to the ventral than to the dorsal margin.

Diameter $3 \frac{1}{2}$ inches, breadth 2 inches.

Found occasionally in the Chalk with siliceous grains, at Chardstock. M. D'Orbigny quotes it as common in beds of the same age in the North and West of France.

Our specimens have a rounder back and more flexuous septa than M. D’Orbigny's figure of $N$. fleuriausianus, in which characters they approach his figure of $N$. Sowerbyanus, from which they are distinguished by a smaller umbilicus. I am inclined to regard them both as one species, and have adopted the name of $N$. fleuriausianus, as the other would be liable to confusion with the $N$. Sowerbii of the 'Mineral Conchology.' I have only seen casts of the $N$. fleuriausianus, which do not show the siphunculus, and have described its position upon the authority of M. D'Orbigny's figure and description.

\section{Nautilus Fitroni, Sharpe. Plate VI, fig. 4.}

Nautilus compressus, Fitton. Trans. Geol. Soc., 2d series, vol. iv, pp. 203 and 367 , Note.

N. testâ lavi, compressâ, complanatâ, umbilicatâ; lateribus planis, obliquis; dorso angusto, rotundato, in medio lineato; umbilico magno; aperturấ truncato-sagittatâ, apicè rotundatá; siphunculo sub-ventrali; septorum marginibus flexuosissimis.

Shell discoidal, smooth; sides flat, sloping; back narrow and rounded, marked with a faint line along the middle; umbilicus large, allowing the inner whorls to be seen, its walls nearly perpendicular; aperture sagittate with the angles rounded off; septa with a very flexuous margin; siphuncle very near the lower margin of the whorls.

Diameter about 3 inches, breadth 1 inch.

This shell has a good deal of resemblance to N. Saxbii of Morris, in general form, proportions, and flexure of the septa; but differs from that species in its rounded back.

This species was first noticed by Dr. Fitton in the Upper Green Sand, Western Lines Isle of Wight, and placed in the Museum of the Geological Society ; it is called in his lists $N$. compressus, which name had unfortunately been previously applied to another species. It has since been found by Mr. Wiest in the Chalk with siliceous grains of Chardstock; both of the specimens are imperfect. It is named after the original discoverer.

\section{Aмmonites, Bruguière.}

Animal unknown : shell chambered, discoidal, compressed or ventricose, spiral, with contiguous whorls regularly convoluted on the same plane, the last partially or entirely concealing the previous whorl: chambers separated by transverse flexuous septa, deeply sinuated towards the edges, divided into branching lobes, and traversed by a continuous tube situated at the outer or dorsal edge of the shell; the last chamber large. 
Ammonites are distinguished from other genera of discoidal chambered Cephalopods by the branching lobes of their mantle, causing the edges of the septa to form a very complicated pattern against the side of the whorl, which is seen when the surface is removed or worn away. The forms of these lobes have been used, as distinguishing specific characters, by Von Buch and many subsequent writers. Although I am not disposed to attach so much importance to them as is sometinies done, I have, as far as possible, given an outline of the lobes of the septa of each species.

To facilitate description, Von Buch proposed to restrict the term lobe to the more subdivided and branching portions of the edges of the chamber which extend downward from the mouth of the shell, and to call saddles the more rounded and less intersected divisions which project upward towards the mouth; thus the outline of a septum is made up of lobes alternating with saddles. The middle of the back of the whorl is occupied by the dorsal lobe, opposite to which is the ventral lobe, which, abutting against the previous whorl, is always concealed: between these are the lateral lobes and saddles. References to these names will be found in the explanation of Plate VII.

In using these characters, the observer must bear in mind that they vary at different ages of the animal, and are therefore practically of less use to the conchologist than might be expected. Not only do all the ramifications of the lobes increase in complexity during the whole life of the Ammonite, a mere notch in the young stage growing into a branch of its lobe, but the number of lobes may also increase with age. According to M. D'Orbigny, all Ammonites have only six lobes at the earliest period of their existence; namely, the dorsal and ventral lobes, and the superior and inferior lateral lobes on each side of the whorl. In some species this number continues the same through life; but more commonly the lobes increase in number with the growth of the shell, small auxiliary lobes being added on each side near the junction with the inner whorl. The number of auxiliary lobes varies in different species; but as this depends on the age of the shell, they form a character of little service. Moreover, as the lobes are most branched near the edge of the whorl, many of the minor ramifications are obliterated on the worn cast of an Ammonite.

The two sides of the shell being usually symmetrical, it is only necessary to figure the outline of the septa of the back and one side. But there are some species of Ammonites in which the siphuncle, instead of being placed at the middle of the back, is often found more or less on one side; and when this is the case, the lobes of the septa are also displaced to the same extent, so that the tube remains in the middle of the dorsal lobe. Most of those species are symmetrical when young, and the change takes place at very different periods of growth in different individuals. This curious irregularity is most often seen in A. denarius, Fittoni, splendens, and Lyelli of the Gault, A. Duncani and Calloviensis of the Kelloway's Rock. 'The displacement usually consists in shifting the tube to one of the angles of the back; but specimens of $A$. Calloviensis are found with the tube placed near the middle of one of the sides. M. D'Orbigny has illustrated this deformity in describing, in the Paléontologie Française, the species liable to it. 
Many species of Ammonites are distinguished by a large lateral process formed on each side of the mouth, either when the animal is full-grown or at intervals during its growth. Such forms are mostly found in the Oolitic Formations, but $A$. rostratus, which is common in the Upper Green Sand, affords a good example of such a mode of growth.

In many of the secondary strata are found pairs of shelly plates of very peculiar structure, which have received various names, and still more discordant explanations, from different authors. Parkinson called them Trigonellites, Von Meyer Aptychus, Deslongchamps Münsteria. They have been thought by many writers to be external bivalve shells of the Lamellibranchiate order; or internal shells of Cephalalopods; Rüppell thought some of them scales of Reptiles; some have been regarded as palatal teeth of Fishes; and II. D'Orbigny has lately considered them the side plates of pedunculated Cirrhipedes. But the opinion which seems to have most probability in its favour is that the Trigonellites were the opercula of Ammonites, which view has been ably supported by Voltz; ${ }^{1}$ the principal reasons for this opinion are derived from the structure of the plates being analogous to that of many opercula, and their having been often found within the open chamber of Ammonites, to the mouths of which their form and size nearly correspond. Each plate is triangular, with one straight edge, which laps over or under the corresponding edge of its fellow plate. The lines of growth are always seen on the concave side of the plates, showing that to have been the external surface. Voltz divides the Aptychi (or Trigonellites) into three sections: lst, the cornei, consisting of a single (?) horny plate, with a flexible fold down the middle; $2 d$, the imbricati, which have a pair of plates with an external horny epidermis, covered internally, that is on the convex side, with calcareous layers laid over one another like tiles; $3 \mathrm{~d}$, the cellulosi, which have a pair of plates with a thick, cellular, calcareous layer on the inner or convex surface. The Trigonellites are rare in the Chalk; those which have been found will be described in connection with the Ammonites to which they are supposed to belong.

In the first volume of the 'Journal of the Geological Society,' p. 232, Mr. Strickland has described some supposed opercula of Ammonites, consisting of one semi-oval calcareous plate, without any suture, which have been found in the Lias: no similar form has yet been found in the Chalk.

Forbes:

1. Ammonites complanatus, Mantell. Plate VII, figs. 1-3.

Ammonites complanatus, Mantell. Fossils of the South Downs, p. 118.

- - Sowerby. Min. Conch., t. 569, fig. 1.

- largilliertiands, D’Orbigny. Paléont. Franç. Terr. Crét., pl. xcr.

A. testâ discoideâ, cumpressissimâ, laviusculâ, tenuiter striatâ; striis numerosissimis flexuosis, umbilicum versus obsoletis, deinde distinctis et ad margines dorsi sub-tuberculatis ;

1 Neves Jahrbuch, 1837, pp. 304 and 432. 
dorso truncato, lateribus subcarinato, medio planiusculo; aperturâ sagittatâ; anfractibus interioribus occultis; umbilico clauso.

Shell discoidal, much compressed, partially smooth, but marked with very numerous striæ, which are only faintly visible on the middle of the whorl, where they curve away from the mouth, and more distinct towards the margin, where they are nearly straight; each of the striæ is produced into a point projecting beyond the edge of the truncated back, thus forming a slight keel on each side of the back; whorls increasing very rapidly in height, and entirely covering the umbilicus; mouth sagittate; lobes of the septa numerous, and much subdivided.

Diameter 8 inches, height of the outer whorl 5 inches, thickness $1 \frac{8}{10}$ ths of an inch.

Found in the Grey Chalk of Hamsey, near Lewes. The species is very rare; and I have only seen the two specimens figured, which were collected by Dr. Mantell, and are now in the British Museum ; M. D'Orbigny states that it is very rare in France, and has been found at Rouen and Cassis, in the beds of the same age as in England.

This species and the next described, A.obtectus, are nearly related, and are remarkable for the rapid increase of the height of their whorls, which entirely close the umbilicus; and also for the great flexure of the upper edges of the lobes of the septa, which project forward in the middle of the whorls, in a very unusual degree.

\section{Ammonites овтестиs, Sharpe. Plate VII, fig. 4.}

A. testâ discoideâ, compressissimâ; lateribus delicatim costatis: dorso truncato, tricarinato; costis numerosissimis, complanatis, medio angulatis et tuberculatis; carinis dorsalibus nodulosis; aperturâ truncato-sagittatâ ; anfractibus interioribus occultis; umbilico clauso.

Shell discoidal, much compressed, with slightly convex sides, and a narrow truncated back; ornamented on the sides with numerous flat ribs, which rising at the umbilicus slope forward in a straight line to the middle of the whorl, whence they bend back at a sudden angle, and continue in a slight curve to the dorsal margin, where they terminate; every second or third rib bears a rounded tubercle at the angle, on the middle of the whorl; and here and there a rib is inserted between the others reaching only from the row of tubercles to the dorsal margin; the angle of flexure of the ribs varies with age, being at first very obtuse, and changing gradually till it becomes about a right angle; back narrow and truncated, with three keels, which are ornamented with small knobs equal in number to the ribs; each lateral keel is marked off from the side of the whorl by an impressed line running very near the edge; whorls increasing very rapidly in height, and entirely covering the umbilicus; section of the whorls sagittate with the point cut off; septa with long, very narrow, and ramified lobes, which are only partially seen in the specimen figured. 
Diameter of our only specimen $2 \frac{3}{4}$ inches, breadth of the aperture $\frac{3}{4}$ ths of an inch, height of the last whorl $1 \frac{3}{4}$ ths of an inch; but the specimen must have been much larger, as it originally. had, at least, one more whorl.

Found by Mr. Wiest at Chardstock, in the Chalk with siliceous grains.

This elegant shell has some characters which are so rare among the Ammonites, that we only know one other species to which to compare it, A. complanatus, Sow. (A. largilliertianus, D'Orb.); it agrees with that species in general form, in the embracing character of the whorls, covering the umbilicus, and in the curve of the septa, which advance towards the middle of the whorl, and fall back towards the ventral and dorsal margins; from this last character combined with the flexure of the ribs we conjecture that the mouth had a sinus in the middle resembling that in the genera Nautilus and Bellerophon. The lobes of the septa have been imperfectly seen; they bear a strong analogy to those of $A$. complanatus, without altogether agreeing with them. The description being taken from a single imperfect specimen is necessarily incomplete: this specimen appears to be unique.

Hor

3. Ammonites falcatus, Mantell. Plate VII, figs. 5_9.

Ammonites falcatus, Mantell. Fossils of the South Downs, t. xxi, figs. 6 and 12.

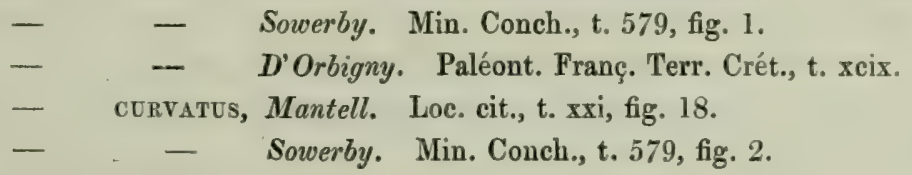

A. testâ discoideâ, compressâ, bicurvato-costatâ, tuberculatâ; tuberculis, costisque. numero variantibus; dorso canaliculato, utrinque tuberculato; umbilico mediocri; aperturá oblongá.

Shell discoidal, and flattened, with numerous ribs extending from the umbilicus to the edge of the back, in double curves, meeting in advancing angles on the middle of the side, and variously tuberculated; back with tubercles on each side, and a hollow canal in the middle; umbilicus of middling size, bounded by steep sides; whorls half concealed; aperture oblong; septa with two lateral lobes, slightly subdivided.

The above are the most constant characters in this very variable species, in which the ribs are either very broad or minutely sub-divided, or replaced by tubercles. The best marked varieties are those which were described by Mantell and Sowerby as distinct species, although specimens may be found with all the characters of both varieties combined, as fig. $\tilde{~}$. A. falcatus originally included the forms without lateral tubercles, as our fig. 7 , and $A$. curvatus the more tuberculated forms, like fig. 6 , which have two rows of tubercles on each side of the back. We are indebted to M. D'Orbigny for uniting them. The tubercles usually diminish in number and prominence, as the shell increases in 
growth; but fig. 8 is a very remarkable variety, in which the tubercles have almost taken the place of the ribs, of which only a few are to be seen in a very young stage.

Diameter 2 inches; thickness $\frac{6}{10}$ ths of an inch.

Found sparingly in the Grey Chalk, the Chloritic Marl, and the Chalk with siliceous grains, throughout the Southern Counties; and also in the Green Sand of Blackdown. It occurs in beds of the same age in France.

A. falcatus is related to $A$. lautus and $A$. tuberculatus, which have a similar canal down the back; but the peculiarly curved ribs readily distinguish it from those species, while its dorsal canal distinguishes it from several species which have ribs with a similar double curve.

4. Ammonimes varians, Sow. Plate VIII, figs. 5-10.

Ammonites varians, Sowerby. Min. Conch., t. 176, lower figures only.

- - Brongniart. Envir. de Paris, t. vi, fig. 5.

- - Bronn. Lethæa Geogn., t. xxxiii, fig. 2.

- - D'Orbigny. Paléont. Franç. Terr. Crét., t. xcii, figs. 3, 4, \& 5.

- $\quad$ - var. intermedia and var. sub-plana, Mantell. Fossils of the South Downs, t. xxi, figs. 2, 5, and 7 .

- Brongniartil, Haan. Amm. et Goniat., No. 43.

A. testâ discoideâ, radiatâ, tuberculatâ, carinatấ; radiis numerosis flexuosis, plerumque furcatis, bi-vel tri-tuberculatis; tuberculis parvis; dorso carinato, lateribus angulatis, tuberculatis, carinâ lavi; umbilico mediocri; aperturá truncato-sagittatâ.

Shell discoidal, ornamented on the sides with numerous flexuous, simple, or forked ribs, each of which bears a small tubercle at its rise on the edge of the umbilicus, and a larger tubercle at its termination on the side of the back, and in some varieties an additional tubercle at the point of bifurcation; umbilicus rather small and well defined; whorls half concealed; back narrow with a prominent keel, and a row of tubercles at each side; section of the whorls considerably higher than broad, sagittate with a truncated top; aperture with the upper part of the whorl projecting forward, and produced into a hlunt point. Septa with 5 or 6 trifid, subdivided lateral lobes.

Ammonites varians, as its name implies, assumes many forms, which may be arranged under the four following varieties:-

1st Var. sub-tuberculata, Pl. VIII, figs. 5, 6, and 8. The young shell has about fifteen slight tubercles round the umbilicus, connected by very faint ribs, with about thirty well-marked tubercles at the edge of the back: the adult shell has the ribs more prominent and less numerous, about twelve rising from the umbilicus, and increasing to about twenty at the edge of the back, an additional distinct tubercle occurs at the bifurcation of each rib, and a row of fainter tubercles usually occurs on the branches of the divided ribs, half-way between the fork of the ribs and the back; making four rows of 
tubercles on each side of the whorl; the margin of the umbilicus is rounded off ; and the width of the aperture varies from seven to eight tenths of its height. This is the commonest form of the species.

2d Var. costatu, Pl. VIII, fig. 9, of the same form and proportions as the preceding, but with mere undulations of the surface in place of ribs; the tubercles round the edge's of the umbilicus and of the back small, but distinct; the other tubercles obsolete. This variety is rare.

3d Var. intermedia of Mantell, Pl. VIII, fig. 7; a much flatter shell than the 1st and $2 d$ varieties, the width of the aperture being only half the height of the whorl; the ribs are prominent and more numerous, twenty in number at the umbilicus, increasing to thirty at the dorsal margin; the dorsal tubercles are distinct, the others inconspicuous. Not very abundant.

4th Var. sub-plana of Mantell, Pl. VIII, fig. 10 ; proportions the same as the last, ribs more numerous, but very slight; dorsal tubercles about fifty, small but distinct; no tubercles on the side of the whorl ; umbilicus small, well-defined, with the side steep, and bounded by an angular edge with very faint tubercles. Abundant at Ventnor in the Isle of Wight.

The first three varieties usually reach a diameter of two inches to two inches and a half; the fourth variety rarely attains an inch and a half in diameter.

Ammonites varians is found abundantly in the Grey Chalk, the Chloritic Marl, the Chalk with siliceous grains, and the Upper Green Sand, wherever those Formations occur in the southern parts of England. It is common in France in beds of the same age.

The $A$. varians of Sowerby included $A$. Coupei, which is here separated from it, in accordance with the views of Brongniart and many other authors. 'The reasons for this separation will be found under $A$. Coupei.

The variations in form of the shells still remaining under $A$. varians are so considerable, as almost to justify our regarding the 1 st and $2 \mathrm{~d}$ varieties as one species, the $3 \mathrm{~d}$ and 4th as another; or, if we admitted M. D'Orbigny's opinion, that the broader shells were females and the flatter ones males, we might take the first two varieties to be the former, and the last two the males : but our present imperfect knowledge of the sexes of living Cephalopods does not justify such a division.

5. Ammonites Codpei, Brong. Plate VIII, figs. 1-4. Plate IX, fig. 1. Ammonites. Coupei, Brongniart. Envir. de Paris, t. vi, fig. 3.

- - Haan. Amm. et Goniat., No. 42.

- - Bronn. Lethæa Geogn., t. xxxiii, fig. 4.

- vartans, Sow. Min. Conch., t. 176, middle and upper figures.

- - var. tuberculata, Mantell. Foss. S. Downs, p. 116.

- - Haan. Amm. et Goniat., No. 45.

- - D'Orbigny. Paléont. Franç. Terr. Crét, t. xcii, figs. 1, 2, and 6. 
A. testâ discoideâ, aliquando sub-inflatâ, costatâ, tuberculatâ, carinatấ; costis interruptis, simplicibus vel furcatis, tri-vel quatuor-tuberculatis; tuberculis prominentibus; dorso latiusculo, utrinque tuberculato, medio carinato; umbilico profundo; aperturâ truncatoovatá.

Shell discoidal, with the whorls inflated when young, but somewhat flattened when adult, ribbed, and tuberculated; back broad and keeled, with a row of prominent tubercles on each side; aperture ovate, with the upper part of the whorl projecting forward, and produced into a blunt point; umbilicus deep and rounded off at its upper edge. The ribs and tubercles vary much both in size and number at different stages of growth and in different varieties of the species. Septa with four trifid, sub-divided lateral lobes.

This species admits of a division into two strongly-marked varieties, which Haan regarded as distinct species :-

1st Var. tuberculata of Mantell, whorls of the young shell (Pl. VIII, fig. 4,) inflated, their width being equal to their height, with three rows of very prominent tubercles connected by thick, ill-defined ribs; the tubercles of the inner row round the edge of the umbilicus are the smallest, ten in number in a very young shell, twelve in a shell of $1 \frac{1}{2}$ inch in diameter; the tubercles of the next row, situated on the middle of the whorl, are very large and prominent, and equal in number to the preceding; the tubercles of the outer row on the edge of the back are of an intermediate size, and about half as many again as the others; in the adult shell (PI. VIII, fig. 2; Pl. IX, fig. 1,) the whorls are a little flattened, the ribs better marked, the tubercles rather less prominent, and a fourth row of small tubercles is inserted between the middle and the dorsal rows; the width of the aperture is equal to $\frac{9}{10}$ ths of the height of the whorl. The usual diameter of this variety is about $2 \frac{1}{2}$ inches, but specimens are occasionally found in the Grey Chalk of 6 inches diameter: this enlargement is not due to an increased number of whorls, but to a larger size at every stage of growth.

2d Var. inflata, Pl. VIII, fig. 1, whorls inflated, their width being one fourth more than their height, with two rows of very large and prominent tubercles; those of the inner row which are seated on the middle of the whorl being the largest, and ten or eleven in number; the outer row on the edge of the back somewhat smaller, and sixteen or seventeen in number; back broad, with a very prominent keel. This variety reached $2 \frac{1}{2}$ inches in diameter, and $1 \frac{1}{4}$ of an inch in thickness.

Ammonites Coupei is common in the Chloritic Marl of the Isle of Wight, and in the Chalk with siliceous grains of Dorsetshire; and is found sparingly in the Grey Chalk of the Southern Counties.

The original description of $A$. varians in the 'Mineral Conchology' included our A. Coupei, which was first separated by Brongniart : most subsequent authors have regarded them as distinct species, until they were reunited by M. D'Orbigny, who considers that all the varieties of the two species pass into one another, and may in part be accounted differences of sex, the more inflated forms being regarded as females. We 
know nothing certain respecting the sexual differences of form in Ammonites; but even if it were admitted that such differences existed, they would not suffice to bring $A$. varians and $A$. Coupei together, as in each species there are two well-marked differences of form, so that there are varieties enough to supply distinct sexes in each species. The young shells of both varieties of $A$. Coupei nearly resemble each other; the differences between them begin in their middle stage, and increase as they grow older, the 1st variety gradually approaching $A$. varians in form, while the $2 \mathrm{~d}$ variety recedes farther from that species. The young $A$. varians always present a strong contrast, in its flat, faintly-ribbed form, to the rounded and tuberculated young shell of $A$. Coupei: it is only in the adult form of one variety of each species that any confusion can arise between them.

6. Ammonites cinctus, Mantell. Plate IX, fig. 2.

Ammonites cinctus, Mantell. Fossils of the South Downs, p. 116.

- - Sowerby. Min. Conch., t. 564, fig. 1.

A. testâ discoideâ ; ambulacris rotundatis, transversim costatis; costis tenuibus, alternatim majoribus furcatis ambulacrum totum amplectentibus, minoribus intermediis dorsalibus; dorso rotundato; umbilico parvo; aperturâ ovali.

Shell discoidal, with rounded whorls crossed by numerous slight, irregularly flexuous ribs; these are twelve in number at the umbilicus, divide into two before reaching the middle of the side, and are continued over the rounded back; between each of the branches of the larger ribs there are one or more short ribs, which only extend across the back; umbilicus small; whorls about two thirds concealed; aperture oval. The septa have not been seen.

Diameter, 3.8 inches; width, $1 \cdot 1$ inch.

From the Grey Chalk of Middleham, Sussex. The figure is taken from Dr. Mantell's original specimen, now in the British Museum. No other specimen of the species is known.

A. cinctus is well characterisd by its very peculiar ribbing, and cannot be confounded with any other species. The specimen shows the form of the mouth very nearly complete.

\section{Hophites}

7. Амmonites Bunburianus, Sharpe. Plate IX, fig. 3.

A. testâ discoideâ, compressâ, lateribus transversim multi-sulcatá, dorso tri-seriatim tuberculatâ: umbilico parvo; aperturâ ovato-rhomboideá.

Shell discoidal with flattened sides; crossed by twenty-five unequal furrows, continued over the back, which is marked by three rows of tubercles; the furrows are very small near the umbilicus, and gradually grow wider and deeper towards the back where they are most important : on the back the spaces between the furrows form broad ribs, each of which has three longitudinally flattened tubercles, one on the middle and one on cach side 
of the back; umbilicus small, with steep sides; whorls more than half concealed; aperture oval; septa with three slightly indented lateral lobes.

Diameter, $1 \frac{1}{4}$ inch ; width, $\frac{3}{8}$ ths of an inch.

Only one specimen has been seen, which was presented by Mr. E. H. Bunbury to the Museum of Practical Geology; it is from the Chalk with siliceous grains of Chardstock, Somersetshire. The species is named after its discoverer.

\section{Ammonites peramplus, Mantell. Plate X, figs. $1-3$.}

Ammonites peramptus, Mantell. Fossils of the South Downs, p. 200.

$$
\begin{aligned}
& -\quad-\quad \text { Sowerby. Min. Conch., t. } 357 . \\
& -\quad \text { D'Orbigny. Paléont. Franç. Terr. Crét., t. 100, figs. 1, } 2 . \\
& \text { - Prosperiands, D'Orbigny. Loc. cit., t. 100, figs. } 3 \text { and 4. }
\end{aligned}
$$

A. testâ subinflatấ: anfractibus rotundatis; junioribus costatis, costis flexuosis, amplectentibus, quarum sex majoribus intus tuberculatis; adolescentibus utrinque undatocostatis, dorso plano; adultis rotundatis, intus sub-undatis; senioribus rotundatis, simplicibus : aperturâ imprimis semi-circulari, deinde ovatâ.

Shell gibbose, with rounded whorls, of which nearly two thirds are concealed, varying in proportions and ornament at different periods of growth; side of the umbilicus very steep; septa with four or five unequally trifid, branching lateral lobes.

The young shell, up to a diameter of two inches, has the whorls broader than they are high, ornamented by about twenty-five rounded ribs, which bend forward as they cross the back; of these six are stronger than the others, and rise from six large pointed tubercles on the edge of the umbilicus, fig. 3, A. prosperianus, D'Orb. At a diameter of four to six inches, the intermediate minor ribs disappear, the tubercles become obsolete, and the back smooth, and there remain about twelve broad, rounded, straight ribs on each side of the whorl, which do not meet on the back, fig. 2 .

When the shells reaches a diameter of a foot, the whorl is higher than broad, and nearly smooth, with no trace of its previous ornament, except a series of blunt ill-defined tubercles round the umbilicus, connected with faint undulations on the inner half of the whorl (fig. 1).

Very old specimens, which may be found exceeding two feet in diameter, have the whorls smooth and entirely devoid of ornament, and the aperture laterally compressed.

A. peramplus is found in the middle part of the Chalk throughout the counties of Kent, Sussex, Surrey, Hertfordshire, and Wiltshire, and the Isle of Wight; but is most abundant in the South Downs. It reaches from the white chalk without flints high up into the chalk with flints, but large individuals are only found in the lower parts of its range, the uppermost beds in which it occurs only containing very small specimens. M. d'Orbigny quotes it only from the Upper Green Sand of the South of France.

M. d'Orbigny conjectured, p. 335 , that his $A$. prosperianus might, perhaps, prove the young of $A$. peramplus, which farther observation has shown to be the case. 
Prionotrunis

\section{Ammonites Woollgari, Mantell. Plate XI, fig. İ and 2.}

Ammonites Woollgari, Mantell. Fossils of the South Downs, t. xxi, fig. 16 ; t. xxii,

fig. 7 .

$$
\begin{aligned}
& \text { - } \quad \text { Sowerby. Min. Con., t. 587, fig. 1. } \\
& \text { - } \quad \text { D'Orbigny. Prodrome de Paléontologie, p. } 189 . \\
& \text { - } \quad \text { (not), D'Orbigny. Pal. Franç., t. 108, fig. 1-3. } \\
& \text { - Carolinos? D'Orbigny. Loc. cit., t. xci, fig. 5, 6. }
\end{aligned}
$$

A. testâ subcompressâ, costatâ, tuberculatâ, interruptè carinatá: juniore, costis 16-1s elevatis, tri-tuberculatis, dorso interruptis, carinẩ dorsali profundè serratâ; adolescenti, costis rarioribus ad dorsum uni-tuberculatis, cariná dorsali obsoletá; adultá, costis bituberculatis, tuberculis maximis, dorso concavo : umbilico lato : aperturâ oblongá.

Shell compressed, ribbed, tuberculated, and keeled; changing its form and ornaments as it enlarges; when two to three inches in diameter it has sixteen to eighteen sharp, elevated ribs on the side of each whorl, each rib bearing three tubercles, one near the umbilicus and two near the back; the back has a sharp and deeply serrated keel, the serrations corresponding in number to the ribs: when about four inches in diameter, the keel is less prominent, the ribs are fewrer and nearly obsolete, and bear one enormous tubercle at their dorsal end: as the shell continues to enlarge, the whorl grows broader, and has two rows of ten very large tubercles on each side, one close to the umbilicus, the other at the dorsal edge, the back has entirely lost its keel, and is smooth and hollow between the dorsal tubercles: umbilicus large and shallow, with two thirds of the whorls exposed: aperture at first oblong and narrow, ultimately nearly of equal height and breadth. The septa have not been clearly seen, they appear to have four or five trifid lateral lobes.

Diameter of old shell, 1 foot; width, 3 inches.

A rare shell in the Middle and Lower Chalk of Sussex.

There is hardly any species of Ammonite which undergoes so great a metamorphosis as A. Woollgari; the young and middle stages of growth were well figured by Dr. Mantell; the older stage is not often met with, the only specimen which I have seen is in Mr. Baber's collection, but is too imperfect to figure. The shell described as A. Woollgari in the 'Paléontologie Française,' has no resemblance whatever to Dr. Mantell's species; this error is pointed out by M. d'Archiac, in the 'Histoire des Progrès de la Géologie,' vol. iv, p. 347, note, and has been corrected by M. d'Orbigny in the 'Prodrome de Paléontologie,' vol. ii, p. 185. In the latter work M. d'Orbigny quotes his $A$. Carolinus, Pal. Franç., t. 91, fig. 5 and 6 , as the young of $A$. Woollgari; which identification is very doubtful, as the French shell has twice as many ribs, is less compressed, and has the keel more completely separated from the ribs by two regular channels, than our species. 


\section{0. Амmonites Grimfithi, Sharpe. Plate XI, fig. 3.}

A. testâ discoideâ lavi, sulcis 4 vel à flexuosis ornatâ: dorso rotundato (impresso?), umbilico parvo: aperturá semiovali: semptorum marginibus ramosissimis, lobis trifidis.

Shell discoidal, smooth; each whorl crossed by four or five slightly waved, transverse furrows, bounded on each side by a slight elevation; back rounded and marked in the cast by a small medial groove; umbilicus small and well defined; whorls four fifths concealed; aperture semi-oval; margins of the septa very complex, with four trifid lateral lobes.

Diameter, 5 inches; width $2 \frac{1}{2}$ inches.

Found in the hard Chalk of Aughanloe and Benbraddagh, in the County of Derry, by the Ordnance Geological Surveyors.

The specimens examined being all internal casts, the above description is necessarily imperfect, and may require modification when better materials are found. The species is nearly allied to $A$. Lewesiensis, Sow., and $A$. Mayorianus, d'Orb.; it is distinguished from the former by its transverse furrows, from the latter by less breadth at the back, and from both by the want of transverse ribs, and a smaller umbilicus: the lobes of the septa of the three species are much alike. The shell is named after Richard Griffith, Esq., to whose labours we are indebted for the Geological Map of Ireland.

\section{Ammonites Austeni, Sharpe. Plate XII, fig. 1 and 2.}

A. testâ cliscoideâ, compressâ, transversim costatâ; costis flexuosis incqualibus, majoribus paucis ambulacrum amplectentibus, minoribus numerosis dorsalibus: dorso rotundato : umbilico parvo : aperturâ rotundato sagittatâ.

Shell discoidal, transversely ribbed: whorls flattened at the sides, rounded over the back, ornamented with numerous unequal flexuous ribs, all passing over the back, of which a few, larger than the rest, embrace the whole whorl, the others only reaching to the middle of the side; the number of larger ribs varies, being eight or ten on the whorl of a young, and about twenty on that of an old shell: back narrow and rounded: umbilicus small, and bounded by steep sides exposing half the inner whorl: aperture bluntly sagittate.

Diameter of the specimen fig. 1, 16 inches; height of outer whorl, 6 inches; width of the aperture, $3 \frac{1}{2}$ inches: it often reaches much larger dimensions.

Found in the Grey Chalk of Surrey, Kent, and Sussex, and in the Upper Green Sand near Dorking.

It is singular that a species to be found in abundance near London should never have been published; it has probably been mistaken by collectors for $A$. planulatus, Sorw, to which it has some resemblance; but that species has transverse furrows where this has 
projecting ribs. I have named it after Robert A. C. Austen, Esq., F.R. and G.S., in whose neighbourhood at Chilworth, this Ammonite is very abundant.

Desmoceras

12. Ammonitis planulatus, Sowerby. Plate XII, fig. 3 and 4.

Ammonites planduatus, Sowerby. Mineral Conchology, t. 570, fig. 5.

A. testâ discoideá: anfractibus complanatis, externè costatis, internè lavibus; sulcis 5 transversis subflexuosis, impressis; costis numerosis, brevibus: dorso rotundato transversim costato: umbilico magno: aperturâ semi-ovatâ : lobis septorum lateralibus incqualiter bifidis.

Shell discoidal, with four or five whorls flattened on the sides, and rounded on the back, crossed by five deep, slightly flexuous furrows, between which are many short slight ribs, which cross over the back and only reach the middle of the side of the whorl: umbilicus large and well-defined, leaving three fifths of the inner whorls visible: aperture semi-oval: lateral lobes of the septa unequally bifid.

Diameter, $2 \frac{1}{2}$ inches.

Rare in the Grey Chalk near Lewes and Bonchurch; common in the Upper Green Sand near Cambridge.

I have seen but few specimens of this species from the Chalk, and as that originally figured by Sowerby is badly preserved and somewhat crushed, and does not show the margins of the septa, a figure is added of a well preserved internal cast from the Upper Green Sand. M. d'Orbigny unites to Sowerby's species, under the name of A. Mayorianus, an Ammonite found in the Lower Green Sand and Gault of France, which differs from our species in having only four transverse furrows instead of five, the furrows more flexuous, and bounded by stronger swellings, and the cast entirely smooth; it has, moreover, the lateral lobes of the septa trifid, which distinguishes it from Sowerby's species. I cannot, therefore, regard his species as identical with ours. M. d'Orbigny's reason for dropping Sowerby's specific name, that it had been previously used by Schlotheim for another species, is also insufficient: since Schlotheim's specics being abandoned by every one, including M. d'Orbigny himself, 'Terr. Jurass.,' vol. i, p. 509, the name remains open for the next species to which it has been applied, which is the one here described.

13. Ammonimes catinus, Mantell. Plate XIII, fig. ].

Ammonites catinus, Mantell. Fossils of the South Downs, t. xxii, fig. 10. (Not t.xxii, fig. 5.)

A. testâ inflatá: anfractibus paucis, latis, rotundatis, lateribus 10-12 tuberculatis, dor: lavibus: umbilico lato, profundo: aperturá transversấ, semi-circulari.

Shell gibbous, with three or four broad whorls, depressed and smooth on the back, 
elevated and tuberculated on the sides near the large and deep umbilicus; tubercles 10 to 12 on each whorl, large and ill-defined; inner whorls half concealed: aperture transverse, nearly semicircular.

Diameter, 10 inches; width of aperture, 5 inches.

Very rare in the Grey Chalk of Wiltshire and Sussex.

This rare Ammonite, of which only two specimens have been met with, is the only species yet known in the Chalk of the Family of the Coronarii, so abundant in the middle Oolites.

A misprint in the explanation of Dr. Mantell's Plate xxii, where fig. 5 , is called $A$. catinus instead of $A$. navicularis, has led to this species being confounded with $A$. Mantellii, both in the 'Paléontologie Française,' and in Bronn's 'Index Paleontologicus.'

\section{Ammonites Pontrocki, Sharpe. Plate XIII, fig. 2 and 3.}

Ammonites fissicostatus, Portlock. Geology of Londonderry, \&c., pp. 408 and 764.

A. testâ inflatâ, costatâ, tuberculatâ : ambulacris rotundatis: juniore, tuberculis lateralibus 10, costis 20 transversis, dorso interruptis; adultä, tuberculis binis, dorsalibus, majoribus; costis rarioribus: umbilico parvo, profundo: aperturâ transversim ovali: septorum marginibus lateraliter trilobatis, lobis trifidis.

Shell gibbous, with few rounded whorls wider than high, and a small deep, smooth umbilicus: when one and a half to two inches in diameter the whorl has ten large blunt tubercles on the middle of each side, and twenty strong rounded ribs, rising either singly or in pairs from the tubercles, and curving slightly forward to near the middle of the back, where they become obsolete; when three inches in diameter only one rib rises at each tubercle, which bears a second larger tubercle near the middle of the back, and the intervening ribs disappear : in the internal cast the back has a slight medial groove: inner whorls nearly half concealed: aperture transversely oval: septa with three trifid lateral lobes.

Diameter, 3 inches; width of aperture 2 inches.

Found in the hard Chalk of Tamlaght, in the county of Derry, by the Ordnance Geological Surveyors.

The young shell bears some resemblance to $A$. fissicostatus, to which this species was first referred, but it is distinguished by more transverse whorls and fewer ribs, and at a later stage of growth by the large dorsal tubercles. I have named it after Lieutenant Colonel Portlock, R.E., who conducted the Geological branch of the Ordnance Survey of Ireland at the time the specimens were found, and first published a notice of them. 
15. Ammonites edomphalus, Sharpe. Plate XIII, fig. 4.

A. testâ inflatâ, costatâ, tuberculatâ: anfractibus latis, dorso depressis, lateribus angulatis, spinosis: costis incequalibus; majoribus alternantibus latero bi-tuberculatis, ad dorsum bifidis: dorso depresso, transversim costato, demum tuberculato: umbilico magno, profundo : aperturấ transversâ, angulatâ : septorum marginibus lobis 4 trificlis simpliciusculis.

Shell gibbous, with a broad flattened back and angular whorls, crossed by numerous unequal tuberculated ribs, which bifurcate at the back; the ribs are about twenty in number on the side of the whorl, alternately larger and smaller; the larger ribs bearing a small tubercle near the umbilicus, and a strong spine at the edge of the back; the number of ribs on the back is about double that on the sides of the whorl, two springing from each spine, curving forwards and meeting again at the opposite spine; about every fourth dorsal rib is larger than the others, and bears two slight tubercles: umbilicus broad and funnel-shaped, leaving three fourths of the inner whorls visible: aperture transverse and angular : septa with four very simple, trifid, lateral lobes, and the lateral saddle very small.

Diameter, three fourths of an inch; width of aperture, half an inch; height of the last whorl, one third of an inch.

From the base of the Lower Chalk, at Man of War Cove, on the coast of Dorsetshire, in the collection of E. H. Bunbury, Esq.

Only one imperfect specimen of this pretty Ammonite has been seen; in many characters it is closely related to $A$. Martinii, D'Orb., having, like that species, the lateral saddle much smaller than the first auxiliary saddle, but it has a flatter back than A. Martinii, and somewhat different ribbing.

Acanthoceras

16. Ammonites laticlavius, Sharpe. Plate XIV, fig. 1.

A. testâ discoideấ: anfractibus paucis, planatis, costatis, tuberculatis; costis 35 radiantibus, 8-tuberculatis, dorso internuptis: umbilico parvo: dorso, marginibus bi-tuberculatis, medio planiusculo: aperturá rhomboidali.

Shell with three or four whorls, flattened on the sides; ornamented on each side with thirty-five equal, straight ribs, each bearing four tubercles, not continued across the back; in the young shell the ribs are either single, or unite in pairs at the umbilicar tubercle, but after reaching a diameter of three inches, each rib is quite distinct: tubercles in eight, nearly equidistant rows, three on the flat side of the whorl, and one on each side of the back: umbilicus small and well defined, leaving four fifths of the inner whorls visible: back smooth and hollow between the tubercles: aperture rhomboidal.

Diameter, $6 \frac{1}{2}$ inches; height of last whorl, 3 inches; width of aperture, $2 \frac{1}{2}$ inches.

A very rare shell in the Grey Chalk of the Isle of Wight.

This species belongs to the large group of Ammonites with squared whorls and straight 
tuberculated ribs, of which $A$. Rhotomagensis is usually taken as the type; the septa have not been well seen.

\section{Ammonites Oldhami, Sharpe. Plate XIV, fig. 2.}

Ammonites alternatus, Portlock. Geology of Londonderry, \&c., pp. 408 and 764.

A. testâ discoideâ: anfractibus ellipticis, transversim radiatis; radiis alternatim majoribus, dorso interruptis: dorso rotundato, impresso: umbilico magno: aperturâ semiovali: lobis septorum trifidis ramosissimis.

Shell discoidal, with slightly flattened, rounded whorls, ornamented with numerous transverse ribs, alternately reaching the umbilicus, or stopping on the side of the whorl, but all interrupted at the back: umbilicus large and shallow, leaving one third of the inner whorls visible: back marked in the internal cast with a slight medial groove: aperture semi-elliptical : margins of the septa with three trifid, branching, lateral lobes.

Diameter, 4 inches; height of last whorl, $1 \frac{3}{4}$ inch, width of aperture $1 \frac{1}{4}$ inch.

Found in the hard Chalk of Dungiven, in the County of Derry, by the Ordnance Geological Surveyors.

This species is closely allied to A. Lewesiensis, Sow., having the same general form and groored back, and nearly similar septa; the most obvious distinction is in the ribs, which in A. Lewesiensis are equal, and all die out on the side of the whorl without reaching the umbilicus. Having only seen one waterworn specimen of $A$. Oldhami, I offer the description of it with some diffidence. It is named after 'Thomas Oldham, Esq., of the Ordnance Geological Survey of Ireland.

A. alternatus, Woodward, should be expunged from our catalogues, resting on an exccrably drawn figure of a broken specimen of $A$. interruptus; which I learned from seeing Woodward's original drawing, in the possession of Mr. S. P. Woodward of the British Museum.

\section{Ammonites leptonema, Sharpe. Plate XIV, fig. 3.}

A. testẩ discoideâ, compressiusculâ, transversim subtilissimè costatâ: costis numerosissimis, simplicibus, flexuosis, ambulacrum totum amplectentibus: umbilico magno: dorso angustato, rotundato : aperturá sagittato-ovatá.

Shell discoidal, with four whorls rounded at the umbilicus, and slightly compressed towards the back, enlarging rapidly, and ornamented by very numerous, equal, fine, threadlike, flexuous ribs, which embrace the whole whorl; umbilicus large and shallow; back narrow, and rounded; aperture ovate.

Diameter, $1 \frac{3}{4}$ inch, height of last whorl, seven eighths; width of aperture, five eighths of an inch.

Very rare in the Grey Chalk of Ventnor, Isle of Wight. 
This species resembles $A$. Velleda, Mich., in its general form and elegant thread-like ribs, but is at once distinguished by its larger umbilicus. The specimen figured is the only one which has come under my notice.

inetacan hortites

19. Амmonites Rhotomagensis, Defrance. Plate XVI, fig. $1-4$.

Ammonites Rhotomagensis, Brongniart. Environs de Paris, t. vi, fig. 2.

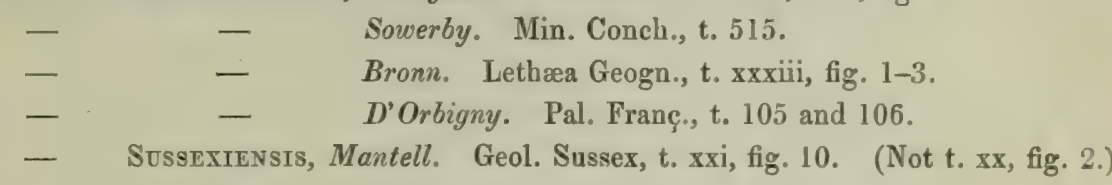

A. testâ discoideá, costatâ, tuberculatâ : anfractibus tumidis, quadruto-rotundatis: costis rectis, simplicibus, rotundatis, cqualibus; junioribus septem, adultis sex-tuberculatis : dorso juniore rotundato, tuberculis triserialibus; adulto bituberculato, transversim costato, ipl medio plano: umbilico magno: septorum lobis lateralibus incequaliter bificlis?

Variat anfractibus planiusculis, tuberculatis; costis subobsoletis; dorso plano.

Shell discoidal; whorls tumid, flattened at the back and sides, with nearly a square section; about one third concealed; crossed by about twenty-four simple, straight, rounded ribs, which when young bear seven tubercles, and when full grown six tubercles each; the tubercles are thus placed,- - one row near the umbilicus, and two rows on each side of the back, the seventh row on the middle of the back disappears in adult shells, leaving the back either smooth and flat, or crossed by a continuation of the ribs; umbilicus large and ill-defined, with sloping sides. The lateral lobes of the septa are unequally bifid?

Diameter, 8 inches; width, $3 \frac{1}{2}$ inches; height of aperture, 3 inches.

Very abundant in the Grey Chalk of all the southern counties, and in the Chloritic Marl of the Isle of Wight, and Chalk with silicious grains of the West of England.

The $A$. Rhotomagensis, as above defined, presents very constant characters; from its youngest stage, fig. 3 , till it has attained about two thirds of its full size, the only changec is a gradual increase in the number of the ribs, but the form and number of the tubercies continues the same; this distinguishes it from A. Sussexiensis and 1. Cunningtom. in both of which the dorsal are, in young shells, more numerous than the lateral tubercles. In the adult $A$. Rhotomagensis the tubercles on the middle of the back disappear; in some specimens the ribs are continued prominently across the back, in others the back is flat and nearly smooth. The size at which the change takes place varies very much. Specimens are often found which, though less than three inches in diameter, have all the characters of the adult shell, one of these is represented of the natural size in fig. 2 ; lut more frequently they reach nearly six inches in diameter before losing the dorsal tubcrches, as in the case of fig. 1. The superior lateral lobe of the scpta is always bificl, with more or less unequal terminal branches; the termination of the next lateral lobe varics, suticic 
specimens having it distinctly trifid, as it is figured in the 'Pal. Franç.,' fig. 106, while others have it unequally bifid.

A marked variety is found in the Chalk with siliceous grains of Somersetshire and Dorsetshire, in which the ribs are nearly obsolete; but the general form of the shell, the tubercles, and the outline of the septa identify the species.

M. d'Orbigny unites A. hippocastanum, Sow., to A. Rhotomagensis, in which I cannot coincide; the unequal ribs of the former contrasting too strongly with the extreme regularity of the latter to admit of their belonging to one species.

20. Ammonites Sussexiensis, Mantell. Plate XV, fig. 1 .

Ammonites Sussexmensis, Mantell. Geol. Sussex, t. xx, fig. 2. (Not t. xxi, fig. 10.)

A. testâ discoideâ, costatâ, tuberculatâ : anfractibus tumidis, quadrato-rotundatis : costis rectis, lateraliter simplicibus, bituberculatis; junioribus, dorso bi-vel tri-divisis, tri-luberculatis; adultis, dorso continuis simplicibus: umbilico magno: septorum lobis lateralibus, primo bifido, secundo trifido.

Shell discoidal; whorls tumid, flattened at the back and sides, with nearly a square section, very little concealed; ornamented with sixteen or eighteen tuberculated ribs; on the sides of the whorls the ribs are all equal, straight, rounded, and bearing two large tubercles, one near the umbilicus, the other near the back; but the dorsal portion of the ribs varies with the age of the shell; at three inches diameter (the youngest examined) each rib divides on the back into two or three ribs, which reunite at the opposite tubercles and bear three small tubercles each; a little later it is only the middle tubercle which is divided into two; after this the rib is continued across the back as in one form of $A$. Rhotomagensis: umbilicus very large, concealing hardly one fifth of the inner whorls. The superior lateral lobe of the septa is bifid, the inferior lateral lobe trifid.

Diameter, 6 inches; width, 2 inches; height of aperture, $2 \frac{1}{4}$ inches.

Found occasionally in the Grey Chalk near Lewes, Sussex.

The two shells originally figured in the Geology of Sussex by Dr. Mantell, under the name of $A$. Sussexiensis, belonged to two different species, to one of which the name of A. Rhotomagensis had just before been given in France; the other being the species above described as A. Sussexiensis. The distinctions between them having been overlooked, they were united together by Sowerby in the 'Mineral Conchology,' vol. vi, p. 25, and all subsequent authors having adopted the same view, A. Sussexiensis has been viewed as a synonym of $A$. Rhotomagensis: the adult shells, though a good deal alike, may be distinguished by the number of their ribs, but in their younger stage the differences in the dorsal ribs and tubercles are too great to allow of any confusion between them. 


\section{Ammonites Cunningtoni, Sharpe. Plate XV, fig. 2.}

A. testâ inflatâ, tuberculato-spinosấ: anfractibus tumidis rotundatis; lateraliter biseriatim spinosis; dorso planulatis, tuberculatis: tuberculis dorsalibus imprimis triserialibus, medio numerosioribus, deinde obsoletis: umbilico magno: aperturâ transversim ovali : septorum lobis lateralibus, superiore bifidâ, inferiore trifidá.

Shell with few broad rounded whorls, each with two lateral rows of about ten spinose tubercles, one row of moderate size near the umbilicus, the other of large spines at the edge of the back: three rows of smaller elongated tubercles on the back; those of the two outer rows corresponding in number to the lateral spines; in the central row tiro or three smaller tubercles to each of the others: as the shell increases in size the tubercles of the middle row gradually disappear, and the other dorsal tubercles coalesce with the spines, leaving the back smooth, and only four rows of large spines on the whorl: umbilicus large, leaving nine tenths of the inner whorls visible: aperture transversely oval : superior lateral lobe of the septa bifid, inferior lateral lobe trifid.

Diameter, 6 inches; width, $3 \frac{1}{4}$ inches; height of aperture, $2 \frac{1}{2}$ inches.

The only specimen seen was found in the Grey Chalk of Upton Scudamore, near Warminster.

This species is nearly related to $A$. Sussexiensis, from which it is distinguished by its broader whorls, fewer and larger lateral tubercles, and different arrangement of the dorsal tubercles. The species is named after William Cunnington, Esq., F.G.S., of Devizes, whose zeal in illustrating the Geology of his neighbourhood entitle him to our gratitude. 

22. Ammonites Cenomanensis, D’Archiac. Plate XVII, fig. 1.

Ammonites Cenomanensis, D'Archiac. Mém. de la Soc. Géol. de France, 2me serie, vol. ii, pp. 62 and 78; Histoire des Prog. de la Géol., vol. iv, p. 347 , note.

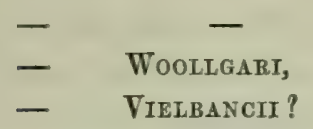

D'Orbigny. Prodrome, vol. ii, p. 146.

Id. Pal. Franç. Terr. Crét., vol. i, t. 108, figs. 1-3.

Id. Prodrome, vol. ii, p. 189.

A. testâ inflatâ, transversim costato-tuberculatâ; anfractibus quadratis; costis numerosis, rectis, atate juniori ad dorsum quinque-tuberculatis, adultâ simplicibus, continuis, bituberculatis; dorso latissimo, utroque latere tuberculato.

Shell inflated; whorls nearly square, crossed by about sixteen thick, straight, equal ribs; each rib starts from a large tubercle on the margin of the umbilicus, and bears another larger tubercle at the side of the back; the very young shell has not been seen; but at 4 inches diameter there are three tubercles on the dorsal part of each rib, between the two larger ones already mentioned; at the diameter of 8 or 9 inches these three tubercles are lost in a strong straight rib crossing the back, and forming right angles at its continuation with the lateral ribs; in the still older shell, of a foot in diameter, the ribs are less prominent, but the two tubercles at the sides of the back project $1 \frac{1}{2}$ inch.

Largest diameter, 1 foot; width, 5 inches; height of aperture, 4 inches.

Common in the Grey Chalk of Kent, Surrey, and Sussex.

This Ammonite is so closely related to A. Rhotomagensis, that it may perhaps be only a variety of that species. The principal differences are in the ribs of the old shells, which in $A$. Rhotomagensis become less and less distinct, till they finally disappear; in A. Cenomanensis grow very prominent and square, and finally run into large projecting horns. It appears to have been distinguished by M. D'Archiac and M. D'Orbigny independently. The latter author first confounded it with $A$. Woollgari, of Mantell, with which it has little in common; but M. D'Archiac gave it the name which it must retain.

23. Ammonites hippocastanum, Sowerby. Plate XVII, figs. 2, 3, and 4.

Ammonites hippocastanum, Sowerby. Mineral Conchology, t. 114, fig. 2.

A. testâ inflatâ, costatâ, spinoso-tuberculatâ ; anfractibus paucis, celeriter crescentibus, angulatis; costis $12-20$ valde incqualibus, tuberculatis : tuberculis 7 seriatis, incqualibus; lateralibus interdum spinosis: dorso lato, 5 tuberculato: umbilico parvo, profundo: aper. turẩ transversim rhomboideá.

Shell gibhose, with few broad and angular whorls, which increase rapidly in size, ornamented with transverse, unequal ribs, and seven rows of large unequal tubercles: 
when young, the ribs are about twelve in number, nearly equal, each bearing seven tubercles; one large, close to the umbilicus; another, very large and conical, near the side of the back; and three on the back, which are smaller and compressed laterally : in the middle stage there is occasionally one small rib, bearing three or five tubercles, between the larger ones; and in the adult shell there are usually two such smaller tuberculated ribs between the principal ones, making about twenty ribs on the whorl, and the tubercles are very unequal in size: back very broad: umbilicus small and deep, exposing half the inner whorls: aperture transversely rhomboidal: septa with a very broad dorsal saddle, and two lateral lobes, of which the superior is bifid; the other has not been well seen.

Diameter, $2 \frac{1}{2}$ inches; height of last whorl, $1 \frac{1}{4}$ inch; width of aperture, $1 \frac{1}{2}$ inch.

Tolerably common in the Chalk with silicious grains of Lyme Regis, Dorsetshire; and Chardstock, Somersetshire.

Many of the Continental authors have united this species with A. Rhotomagensis, probably without having seen the shell, which appears to be confined to one bed in the West of England. When very young the two shells are nearly alike; but A. lippocastanum may be known by its greater breadth of whorl, and large lateral spines. As it increases in size, it is distinguished by the rapid enlargement of its whorls, great breadth, and great inequality of its ribs and tubercles; while $A$. Rhotomagensis is, at all its stages, known by their uniformity. A. Cunningtoni has more affinity to A. hippocastanum; but not having seen the young state of that shell, I am unable to compare them thoroughly.

\section{Ammonires Goupiliands, D'Orbigny. Plate XVII, figs. 5, 6.}

Ammonites Goupilianus, D’ Orbigny. Paléont. Franç. Terr. Crét., t. xciv, figs. 1-3.

A. testâ discoideâ, compressâ, carinatâ, transversim undato-costatâ ; costis depressis, numerosis incqualibus bicurvatis: dorso obtuso, carinato, producto: anfractibus tribus, ad umbilicum declivibus, sub-carinatis, deindè sub-sulcatis, compressis: umbilico mediocri: aperturâ elongato-ovatâ : septorum lobis lateralibus 6 , trifidis.

Shell discoidal, flattened on the sides, keeled; ornamented with numerous unequal, flexuous ribs, which, rising from the raised edge of the umbilicus, incline forward for two fifths of the width of the whorl, then bend slightly backwards, and again bend forward near the back, and are produced forward at the keel, marking the outline of the mouth of the shell at its successive stages of growth; a few of the ribs are stouter than the rest: umbilicus of moderate size, exposing about one fourth of the inner whorls, and bounded by nearly perpendicular walls : sides of the whorls depressed into a slight channel near the umbilicus : back obtuse, with a sharp keel, and projecting in a point over the oval mouth : septa with six trifid lateral lobes. In the youngest stage of growth seen, the larger ribs 
rise into a tubercle near the umbilicus, and also on each side of the back : the old shell is nearly smooth, with faintly marked obsolete ribs.

Diameter, 3 inches ; height of the last whorl, $1 \frac{1}{4}$ inch; width of aperture, 1 inch.

From the Grey Chalk of Hamsey, near Lewes. The only specimen seen is in the British Museum, from the collection of Dr. Mantell. In France it has been found in the Grey Chalk near Saumur, and in the Upper Green Sand of Mondragon, near Orange. (D’Orbigny, loc. cit., p. 319.)

With some general resemblance to the variety sub-plana of $A$. varians, this species is distinguished from that and all the other known species of the Chalk by the depression of the sides of the whorl near the umbilicus, and the peculiar sigmoidal flexure of the ribs, in which characters it is related to $A$. serpentinus, Schloth., and several other species of the Lias and Lower Oolite.

25. Ammonites Vellede, Michelin. Plate XVII, fig. 7 ; and Plate XIX, fig. 6.

Ammonites Vellede, Michelin. Magasin de Zoologie, t. xxxv.

- - D'Orbigny. Paléont. Franç. Terr. Crét., vol. i, t. Ixxxii.

- $\quad$ - Pictet and Roux. Foss. des Grés Vert des env. de Genève, t. ii, fig. 1.

A. testâ discoideâ, compressâ, transversin subtilissimè costatâa: anfractibus paucis, lateribus complanatis, dorso rotundatis : costis tenuibus, rectiusculis, numerosissimis, anfractum totum amplectentibus: umbilico minimo: aperturâ elongato-ovatâ, septorum lobis lateralibus trifidis.

Shell discoidal compressed, with few whorls, flattened on the sides, and rounded at the back; crossed by numerous fine, equal, thread-like ribs, which embrace the whole whorl : umbilicus very small :* aperture elliptical : lateral lobes of the septa trifid.

Diameter, $1 \frac{3}{4}$ inch ; height of the last whorl, 1 inch; width of aperture, $\frac{1}{2}$ inch.

Found rarely in the Upper Chalk near Norwich, and in the Grey Chalk of Ventnor, Isle of Wight. In France and Savoy it is found in beds of the age of the Gault, attaining a diameter of 7 inches.

26. Ammonites navicularis, Mantell. Plate XVIII, figs. $1-3,5,8$.

Ammonites navicularis, Mantell. Fossils of the South Downs, t. xxii, fig. 5.

$$
\begin{aligned}
& \text { - } \quad \text { - Sowerby. Min. Conch., 555, fig. } 2 . \\
& \text { - - D'Orbigny. Prodrome, vol. ii, p. } 146 . \\
& \text { - Gentoni, Brongniart. Env. de Paris, t. vi, fig. } 6 . \\
& \text { - Mantelli, D'Orbigny. Paléont. Franç. Terr. Crét., t. } 103 . \\
& \text { - Milletianus, Dixon. Geol. of Sussex, t. xxix, fig. } 15 .
\end{aligned}
$$

* Owing to the specimen, pl. xrii, fig. 7 , consisting of very soft Chalk, the umbilicus has been too much excavated, and is represented too large. 
A. testâ inflatâ, costatâ, interdum tuberculatâ: anfractibus rotundatis: costis rectis, simplicibus, incequalibus, ad dorsum continuis; junioribus tuberculatis; adultis angulatis, vel rotundatis: dorso rotundato, transversim costato, juniore trituberculato: umbilico parvo, profundo: aperturâ semi-ellipticá: septorum lobis lateralibus, primo incqualiter bifido, cateris trifidis : variat angulis, tuberculisque costalibus plus, minusvé conspicuis.

Shell inflated, with few rounded or angular whorls, crossed by numerous strong, unequal ribs: back round, or angular at the sides: umbilicus small and deep, with half the inner whorls visible: ribs alternately longer and shorter; the longer ribs commence from a tubercle at the edge of the umbilicus, and sometimes bear a second tubercle on each side of the whorl ; the shorter ribs rise on the side of the whorl, nearer to the umbilicus than to the back; all the ribs cross the back: in young shells there are three tubercles on the dorsal part of each rib, which give a slight angularity to the back and to the mouth; in older shells the rib is strong and prominent over the back, without any tubercles, and the back and the mouth are rounded: the superior lateral lobe of the septa is unequally bifid, the two others are trifid; only two lateral lobes are visible on the side of the whorl, the second auxiliary lateral lobe being on the slope of the umbilicus.

Diameter, $4 \frac{1}{2}$ inches; height of last whorl, 2 inches; width of aperture, 2 inches.

Common in the Lower Chalk of the South of England.

This species was first described by Dr. Mantell from a very imperfect specimen, but was afterwards admirably figured in the 'Mineral Conchology ;' nevertheless it was united to A. Mantelli by D'Orbigny, Broun, and other Continental writers. They are, however, to be distinguished when young by the row of tubercles on the middle of the hack of $A$. navicularis, and when old by the ribs of that species continuing elevated over the middle of the back; while in $A$. Mantelli there is a depression on the middle of the back at all periods of its growth. A. Mantelli is usually flatter, more angular, and more tuberculated than $A$. navicularis, but there are varieties which differ in these respects. The species are both found in the Lower Chalk; but I have seen no specimens of $A$. navicularis from the Upper Green Sand. In the 'Prodrome de Paléontologie,' M. D'Orbigny has again separated the two species.

A. Gentoni of Defrance and Brongniart, is the young of $A$. navicularis, in the condition of my figure $5 c$.

A. Milletianus of Dixon (not of D'Orbigny), is one of the many forms of this species, nearly the same as my figure 5 .

27. Ammonites Mantelli, Sowerby. Plate XVIII, figs. 4-7.

Ammonites Mantelli, Sowerby. Min. Conch., t. lv.

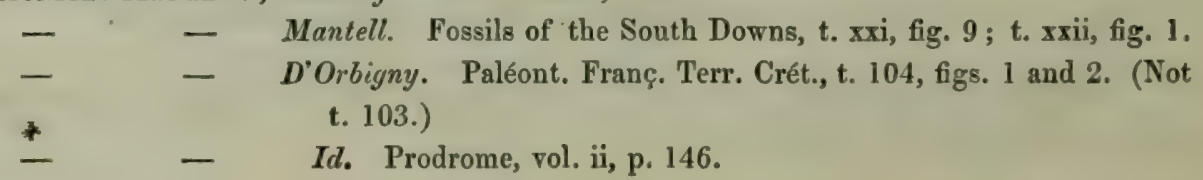


A. testâ discoideâ, costatâ, tuberculatâ : anfractibus angulatis : costis simplicibus, rectiusculis, incequalibus; ad dorsum subcontinuis vel obsoletis, bituberculatis; ad laterâ 1, 2, vel 3 tuberculatis: dorso angulato, medio depresso: umbilico parviusculo: aperturâ rhomboideâ: septorum lobis lateralibus, primo incqualiter bifido, ceteris trifidis.

Var. A. Anfractibus tumidis: aperturâ octangulari; costis rectis, majoribus 8 tuberculatis, minoribus 6 tuberculatis; tuberculis spinosis.

Var. B. Anfractibus compressis : aperturä angulato-ovali : costis subflexuosis : tuberculis dorsalibus conspicuis, cateris obsoletis.

Shell discoidal, with twenty to twenty-five tuberculated ribs, alternately long and short: whorls angular, depressed or tumid: ribs simple and usually straight, the longer ones commencing at a tubercle at the edge of the umbilicus, the shorter below the middle of the whorl, and all continuing across the back, with a depression in the middle of the back : tubercles varying from four to eight rows, of which the umbilical and dorsal rows are always present, the lateral rows being either well or faintly marked, or altogether absent: back depressed in the middle, with a row of tubercles on each side: umbilicus small and deep, allowing half the inner whorls to be seen : aperture rhomboidal : septa with three lateral lobes, the first unequally bifid, the others trifid.

Var. A. Whorls tumid: aperture octangular : ribs straight, with eight rows of large tubercles.

Var. B. Whorls flattened : aperture nearly oval : ribs slightly flexuous : dorsal tubercles distinct, the others nearly obsolete.

Diameter, 3 inches; height of last whorl, $1 \frac{1}{4}$ to $1 \frac{1}{2}$ inch ; width of aperture, $1 \frac{1}{4}$ to $1 \frac{3}{4}$ inch, according to the variety.

Found in the Lower Chalk and the Upper Green Sand of the South of England, and in beds of the same age throughout France.

The distinction between this species and $A$. navicularis will be found after the description of that species.

Hop?ill

28. Ammonites Renauxianus, D’Orbigny. Plate XIX, fig. 2.

Ammonttes Renauxianus, D'Orbigny. Paléont. Franç. Terr. Crét., t. xxrii.

A. testâ discoideâ, compressâ, tuberculato-costatâa: costis bi-vel tri-fidis, flexuosis, bituberculatis, ad dorsum sub-interruptis: dorso bituberculato ; juniore transversim sub-costato; adulto sub-carinato : umbilico mediocri : aperturâ truncato-ellipticá.

Shell discoidal, compressed, with few whorls, ribbed and tuberculated: ribs, about fifteen, bifid or trifid, each springing from a large tubercle near the edge of the umbilicus, and dividing into two or three flexuous branches, each of which bears another tubercle at the edge of the back : in young shells the ribs are faintly continued across the back; but 
in older specimens they end at the side of the back, and there is a slightly elevated ridge along the middle of the back, with a row of tubercles on each side; these dorsal tubercles are elongated transversely in the direction of the ribs: umbilicus shallow, leaving nearly half of the inner whorls visible : aperture nearly elliptical.

Diameter of the figured specimen from the Grey Chalk, $1 \frac{3}{10}$ inch; height of the last whorl, $\frac{6}{10}$ inch; width of aperture, $\frac{4}{10}$ inch.

Rare in the Grey Chalk of Ventnor, Isle of Wight. It is also found in the Upper Green Sand, near Dorking, where it attains a diameter of 4 inches. In France it has been found in the lower part of the "Craie Chloritee."

Not having seen the young stage of any specimens of $A$. Renauxianus found in the Upper Green Sand, it is with some hesitation that I unite to that species these small shells found in the Lower Chalk. On a side view, they closely resemble $A$. varians, from which they differ in the form of the back, which never rises into a decided keel as in that species. The dorsal tubercles are also different, as they slope with the rib; while in $A$. varians they are compressed transversely to the rib, and parallel to the keel.

29. Ammonites octo-sulcatus, Sharpe. Plate XIX, fig. 3.

A. testâ discoideâa : anfractibus complanatis; dorso rotundatis, subtrilissimè costatis; sulcis 8 transversis, rectiusculis, impressis; costis numerosis, brevibus, dorsum amplectentibus: umbilico mediocri : aperturâ semi-ovatâ.

Shell discoidal; with few whorls, flattened on the sides, and rounded on the back, crossed by eight deep, very slightly flexuous furrows, between which are many short, delicate ribs bending forward, and well defined on the back, fading away in the middle of the sides of the whorl: umbilicus rather small, leaving a fourth of the inner whorls visible: aperture semi-oval.

Diameter, 1 inch; width of aperture, $\frac{3}{8}$ inch; height of last whorl, $\frac{4}{10}$ inch.

Found in the Grey Chalk of Ventnor, in the Isle of Wight, and in the Chalk with silicious grains, of Chardstock.

This species is nearly allied to A.planulatus and A. Mayorianus, of the Lower Chalk, and to A. Guettardi of the Neocomian of the South of France. It differs from the first two in having the constrictions more numerous, and the inner whorls more concealed; and from the last, in laving the furrows straighter, and projecting more forward, a rather larger umbilicus, and flatter sides to the whorl. Unfortunately the septa have not been seen. A. Belus, D'Orbigny, lias a similar form and ornaments, but the furrows incline backwards on crossing the back; while in all the other species just mentioned, they project forwards at the middle of the back. 


\section{Haploceras}

30. Ammonites Icenicus, Sharpe. Plate XIX, fig. 4.

A. testâ discoideâ, compressâ, lavi, inornatâ : anfractibus paucis : umbilico mediocri: dorso rotundato: aperturâ ovatâ: septorum lobis lateralibus, primo trifido, Eacteris incequaliter bifidis.

Shell discoidal, smooth; with few whorls, flattened on the sides, and rounded on the back: umbilicus of middling size, allowing two fifths of the inner whorls to be seen; aperture ovate : septa with four lateral lobes, the first trifid, the others unequally bifid.

Diameter, 2 inches; height of last whorl, 1 inch; width of aperture, $\frac{1}{2}$ inch.

Rare in the Upper Chalk near Norwich.

The Ammonite here described has few characters by which it can be distinguished, and may perhaps prove to be only a young shell. But the Upper Chalk contains so few Ammunites, that it is desirable to place on record all that are known. It belongs to the same group as $A$. Lewesiensis.

31. Ammonites Deveriands, D' Orbigny. Plate XIX, fig. 5.

Ammonites Denerianus, D'Orbigny. Paléont. Franç. Terr. Crét., t. 111 , figs. I and 2.

A. testâ inflatâ, transversim tuberculato-costatâ: anfractibus paucis, lateribus compressis, dorso rotundatis: costis incqualibus, simplicibus vel bifurcatis, 9 tuberculatis: aperturâ quadrato-rotundatâ: umbilico magno.

Shell discoidal; with few whorls, flattened on the sides, and rounded at the back, crossed by numerous tuberculated ribs, which are continued over the back: about half the ribs commence at a tubercle on the edge of the umbilicus, and are either simple or bifurcating; between these there is often a shorter rib, commencing on the middle of the side of the whorl; all are equal on the back : tubercles large and round, in nine rows; viz., three on each side, and three on the back; the dorsal rows containing about twice as many as the unbilical row : umbilicus very large, leaving nearly two thirds of the inner whorls visible: aperture nearly square, with the corners rounded off.

Diameter, 4 inches; height of last whorl, $1 \frac{3}{4}$ inch; width of aperture, $1 \frac{5}{8}$ inch.

From the Grey Chalk of Sussex. The only specimen seen is in the British Museum, from the collection of F. Dixon, Esq. It has been found in France in the "Craie Chloritée" of Uchaux.

This species is readily distinguished from all others by the number and position of the tubercles. 
32. Ammonites nusticus, Soverby. Plate XX, fig. 1.

Ammonites Rusticus, Sowerby. Min. Conch., t. 177.

- - - D'Orbigny. Paléont. Franç. Terr. Crét., t. 111, figs. 1 and 2.

A. testâ discoideâ, tuberculatấ: anfractibus paucis, rotundatis: tuberculis 4 seriatis; 2 lateralibus distantibus, maximis, conicis; 2 dorsalibus minoribus, depressis, numerosis: umbilico maximo: dorso rotundato, medio plano.

Shell discoidal, tuberculated, with few rounded whorls : umbilicus very large, rounded at the sides, exposing three fourths of the inner whorls: tubercles in four rows, viz., one on each side of the whorl, a little above the middle, of ten or twelve very large, conical tubercles; and two on the back, of about twenty-four smaller, rounded, depressed tubercles : aperture nearly round.

Diameter, 6 inches; height of last whorl, $2 \frac{1}{2}$ inches; width of aperture, 2 inches.

A very rare shell, found in the Lower Chalk near Lyme Regis, Dursetshire.

33. Anmoninus Renevieri, Sharpe. Plate XX, fig. 2.

A. testâ discoideâ, compressâ : umbilico parvo: aperturâ truncato-hastatâ : septorum lobis lateralibus tribus trifidis: atate juniore, undato-costatâ, tuberculatâ; tuberculis 4 seriatis, ad umbilicum paucis, majoribus, dorsum versus elongatis, numerosis; dorso subcarinato; adultâ omnino levi, dorso rotundato.

Shell discoidal, with few flat whorls: umbilicus small, leaving half the inner whorls visible: mouth truncato-hastate: septa with three trifid lateral lobes: at the diameter of four inches, as in the specimen figured, the whorls have their sides ornamented with about ten ribs, each springing from a round tubercle at the edge of the umbilicus, reaching across half the width of the whorl, and then changing to a flattened undulation, which ends at the side of the back in a tubercle, elongated in the direction of the whorl; alternating with these ribs are similar flattened undulations, ending in similar tubercles: back faintly keeled in the middle: in older specimens the sides are quite smooth, and the back rounded.

Diameter, $6 \frac{1}{2}$ inches; height of last whorl, $3 \frac{1}{4}$ inches, width of aperture, 2 inches.

Found in the Grey Chalk near Bonchurch, Isle of Wight, and near Devizes.

This species has probably been overlooked from its resemblance to some of the forms of $A$. varians, from which it is to be distinguished by straighter and more simple ribbing, and by the septa, which have the dorsal saddle divided into three parts, in a mamner which rarely occurs in this genus. I have named the species after M. E. Renevier, whose labours among the Cretaceous Rocks of Switzerland deserve our warmest thanks, and who has lately visited this country with the view of helping to bring into harmony the synonymy of the Cretaceous Fossils of England and the Continent. 
Toplitec

\section{Ammonites Saxbir, Sharpe. Plate XX, fig. 3.}

A. testẩ discoideâ, compressâ, tuberculato-costatâa: anfractibus paucis, complanatis, angulatis : dorso plano, bi-tuberculato: costis rectis 8-10 majoribus tri-tuberculatis, $20 \mathrm{mi}$ noribus bi-tuberculatis : aperturâ rhomboideá: septorum lobis lateralibus bificis.

Shell discoidal, compressed; whorls few, flattened on the sides : back flat, with angular edges, and a row of tubercles on each side : ribs about thirty, straight, of which eight or ten rise from a tubercle on the edge of the umbilicus, and the others begin on the middle of the side of the whorl; all ending in a large tubercle at the side of the back, and also bearing a smaller tubercle before reaching the back; there being either two or three of the smaller ribs between every two longer ones: aperture rhomboidal: umbilicus small, bounded by steep sides, and allowing two thirds of the inner whorls to be seen : lateral lobes of the septa bifid.

Diameter, 1 inch; height of the last whorl, $\frac{1}{2}$ inch ; width of the aperture, $\frac{3}{8}$ inch.

Rare in the Grey Chalk of Ventnor, Isle of Wight.

A pretty little shell, readily distinguished from all the varieties of $A$. varians by its straight ribs and want of keel. It is named after S. Saxby, jun., Esq., who has rendered me much assistance in collecting together the fossil species of the Chalk of the Isle of Wight.

35. Ammonites Vectensis, Sharpe. Plate XX, fig. 4.

A. testâ discoideâ: anfractibus, lateribus compressis, dorso rotundatis, transversim costatis: costis incequalibus, flexuosis, supra dorsum continuis: umbilico mediocri; aperturat ovali.

Shell discoidal, with few whorls, which are flattened on the sides, rounded at the back, and crossed by about twenty flexuous, slightly elevated ribs; the ribs commence at the edge of the umbilicus, and slope forward to the middle of the side of the whorl, where they bend backwards a little way, and then again slope forwards over the back; besides these there are about ten shorter ribs occasionally inserted between the former, which only begin on the middle of the side, and equally cross over the back : umbilicus of moderate size, leaving more than half the inner whorls exposed: aperture oval : septa not seen.

Diameter, $2 \frac{1}{4}$ inch; height of last whorl, 1 inch; width of aperture, $\frac{5}{8}$ inch.

Only one imperfect specimen has been seen, which was found in the Chloritic Marl, near Ventnor, Isle of Wight.

This species is related to $A$. consobrinus, D'Orbigny, and $A$. cinctus, Sowerby, but is not in danger of being confounded with either. It is also related to $A$. undatus, Sowerby; but 
I find it impossible to compare them properly, for the original specimen of $A$. undatus which Mr. J. de C. Sowerby has had the kindness to lend me, is so much crushed, that its real characters cannot be distinguished; and that name had better be omitted from our lists.

\title{
36. Ammonites Lewesiensis, Mantell. Plate XXI, fig. 1.
}

\author{
Ammonites Lewesiensis, Mantell. Fossils of the South Downs, t. 22, fig. 2. \\ - - D'Orbigny. Paléont. Franç. Ters. Crét., t. 102, figs. 1, 2 ? note \\ t. 101.
}

A. testâ subinflatấ: anfractibus rotundatis, lateraliter sub-compressis, undato-costatis; dorso lavi rotundato: umbilico parvo: aperturâ ovatâ: septorium lobis lateralibus 4 inequaliter trifidis.

Shell inflated: whorls few, with their sides a little flattened, and crossed by about twelve broad, radiating undulations, or indistinct ribs, which commence at the edge of the umbilicus, and die out before reaching the rounded, plain back: umbilicus rather small, with steep sides, allowing above one third of the inner whorls to be seen: aperture oval; septa with four unequally trifid lateral lobes, and a very narrow dorsal lobe.

The young shell differs little from the adult; it has the same plain, round back, but the undulations are hardly visible till it has reached a diameter of 4 to 6 inches : in very old shells, of 2 feet in diameter, the outer whorl becomes quite smooth.

This is one of the largest species of Ammonite found in the Chalk, sometimes exceeding two feet in diameter: the dimensions of the specimen figured are-diameter, 16 inches; height of the last whorl, 6 inches; width of the opening, 5 inches.

Rather rare in the Grey Chalk near Lewes and Dover.

Three species have been published under the name of $A$. Lewesiensis by Mantell, Sowerby, and D'Orbigny. The description and figure given by the first are so imperfect as to have made me almost despair of ascertaining what it represented, until Mr. Woodward discovered Dr. Mantell's original specimen in the vaults of the British Museum. The specimen is very imperfect, a part of the back on the younger side of the whorl being worn off, and the whole being so much crushed as to reduce the size of the umbilicus considerably, and to render the whorls flatter, and the back less round, than in perfect specimens : nevertheless it is sufficient to enable us to recognise the species with certainty.

$A$. Lewesiensis, when full grown, much resembles $A$. peramplus; but it is flatter, and the undulations are continued all across the side of the whorl, instead of stopping in the middle of its side, as in A.peramplus. The young shells of the two species have no resemblance, $A$. Lewesiensis being nearly smooth, and the other ornamented with numerous ribs, which cross over the back. The form of the lateral lobes of the septa is nearly the same in the two species; but in $A$. Lewesiensis the dorsal lobe is very narrow, while 
in A. peramplus the dorsal lobe is broad, and the superior lateral lobe thrown in consequence farther from the middle of the back.

The A. Lewesiensis of the Mineral Conchology (my A. leptoplyllus) has flatter whorls, a narrower aperture, more distinct ribs, an impressed line along the middle of the back, and the lateral lobes of the septa branching into most complicated subdivisions, in strong contrast with those of the true $A$. Lewesiensis. Hitherto it has only been found in the Upper Chalk.

M. D'Orbigny's shell has no resemblance whatever to the A. Lewesiensis of Mantell, and very little to that of Sowerby. It is readily distinguished by a series of numerous short ribs, which, commencing outside the middle of the whorl, are continued towards the middle of the back, where they are suddenly interrupted by an impressed line : the septa are as minutely subdivided as in A. leptophyllus, but the lateral lobes are straight and regularly trifid. It is stated in the 'Paléont. Franç.,' that this species is found in France, in the Lower Chalk: here I have only received it from the North of Ireland, from a bed which I suspect to belong to the Upper Chalk. In the 'Prodrome de Paléontologie,' p. 212, M. D'Orbigny, has named this species A. Gollevillensis, having learned that it differs from the A. Lewesiensis of Sowerby, and he removes its habitat from the Terrain Turonien, or Grey Chalk, wherein he quoted it in the 'Paléontologie Française,' to the Terrain Sénonien, or White Chalk.

M. d'Archiac, in his 'Histoire du Progrès de la Géologie,' quotes A. Lewesiensis as peculiar to the Lower Chalk of France; but I do not know to which of the three species here mentioned he alludes.

\section{Ammonites Wiestir, Sharpe. Plate XXI, fig. 3.}

A. testâ discoideâ, costatâ : anfractibus paucis inflatis: costis $24-30$ prominentibus, incqualibus: dorso rotundato, costato: umbilico parviusculo, profundo: aperturâ semiovatâ.

Shell discoidal, with few inflated whorls, ornamented with twenty-four to thirty strong, rounded ribs of unequal length, of which ten rise near the edge of the umbilicus, and the rest near the middle of the side of the whorl, and all are continued across the broad, rounded back, where they incline a little backwards: umbilicus deep and rather small, allowing half of the inner whorls to be seen : opening semi-ovate : the lobes of the septa have not been seen.

Diameter, $2 \frac{3}{4}$ inches ; height of the last whorl, $1 \frac{1}{4} \mathrm{inch}$; width of the opening, $1 \frac{1}{8} \mathrm{inch}$.

Very rare in the Chalk with silicious grains, Chardstock, Somersetshire.

I have seen only one specimen of this elegant Ammonite, which I have named after its discoverer, J. Wiest, Esq., of Chardstock, from whom I have received great assistance in the preparation of this work. 
38. Ammonites leptophyluus, Sharpe. Plate XXI, fig. 2, and Plate XXII, fig. 1.

Ammonttes Lewesiensis, Sowerby. Mineral Conchology, t. 358.

- $\quad$ - D'Orbigny. Prodrome de Paléontalogie, vol. ii, p. 189.

A. testâ discoideâ, compressâ, undulato-costatâ : anfractibus lateraliter costatis, dorso lavibus: costis numerosis, paulum elevatis: dorso rotundato lavi, lineâ angusta impresso: umbilico parvo: aperturâ elevato-ellipticá : septorum lobis lateralibus ramosissimis, ramis irregulariter alternantibus.

Shell discoidal, flattened at the sides, rounded at the back : sides of the whorls crossed by numerous radiating undulations, or low, broad ribs, which commence at the umbilicus, and die out before they reach the back: umbilicus small, bounded by steep sides, allowing more than half the inner whorls to be seen: back smooth and rounded, marked with a narrow, impressed line: opening high and narrow : lobes of the septa much subdivided; the superior lateral lobe very large, with numerous irregularly alternate branches, ending in long, pointed digits. In very old specimens the undulations are very faint, and gradually disappear.

This species reaches a diameter of more than $2 \frac{1}{2}$ feet. 'I'he proportions of the specimen figured are-diameter, 12 inches; height of the last whorl, 5 inches; width of the aperture, 3 inches.

Found in the Upper Chalk of Brighton, Ramsgate, Greenhithe, \&c.; but, from the softness of the chalk in which it occurs, it is very seldom met with in good preservation.

This is not the species originally named by Dr. Mantell A. Lewesiensis, nor is it the species published under that name by M. D'Orbigny in the 'Paléontologie Française,' which is now called A. Gollevillensis; but in his 'Prodrome de Paléontologie,' that author has so far corrected himself as to separate the last-named species from the one here described.

As there have thus been three species passing under the name of $A$. Lewesiensis, it is impossible to know what is meant when this name is cited in geological works; a comparison of the three species is given, after the description of $A$. Lewesiensis.

39. Ammonites Golleviliensis, D'Orb. Plate XVII, fig. 2.

Ammonites Lewesiensis, D'Orbigny. Paléont. Franç. Terr. Crét., t. 101.

- $\quad$ - Id. Prodrome de Paléontologie, vol. ii, p. 212.

A. testâ dissoideâ, compressâ, costatâ : anfractibus lateraliter lavibus, dorso costatis: costis brevibus, numerosis, aqualibus, ad dorsum interruptis: dorso rotundato, costato, lineá 
angust $\hat{\theta}$, costas interrumpente, impresso: umbilico parviusculo: aperturâ ovatâa: septum lobis lateralibus trifidis ramosissimis.

Shell discoidal, whorls smooth and flattened on the sides, and ribbed on each side of the rounded back; ribs short, numerous, and equal, commencing beyond the middle of the side of the whorl, and suddenly interrupted at the middle of the back by a narrow, impressed line: umbilicus rather small, allowing about one third of the inner whorls to be seen : aperture oval : septa very numerous, with minutely subdivided lobes; lateral lobes trifid, with regularly opposite branches.

Diameter, $1 \frac{1}{2}$ inch; height of the last whorl, 2 inches; width of the aperture, $1 \frac{1}{4}$ inch.

Rare in the hard Chalk of the county of Londonderry, which is supposed to be of the age of the Upper Chalk of England.

This species is closely related to $A$. Oldhami, from which it is distinguished by its short ribs, nearly confined to the back, and its smooth sides. In the 'Paléontologie Française,' M. D'Orbigny confounded this Ammonite with Sowerby's A. Lewesiensis (A. leptoplyyllus, Sharpe), and quoted it from the upper beds of the "Craie Chloritée," or on the level of our Grey Chalk. In his 'Prodrome' he separates it from that species, and considers the beds in which it is found as part of the Upper Chalk.

It is difficult to understand how two such different species could ever have been confounded, as the only character common to both is the impressed dorsal line. The lobes of the septa of both are much subdivided, with spiked terminal digits, but in A. Gollevillensis they are trifid, with opposite and extremely regular branches. In A. leptoplyllus they bifurcate several times with very unequal alternating branches, and great irregularity.

Hon intes

40. Ammonitus curvatus, Mantell. Plate VII, figs. 8, 9 ; Plate XXIII, fig. ].

Ammonites curvatus, Mantell. Fossils of the South Downs, p. 118, t. 21, fig. 18.

- - Sowerby. Min. Conch., t. 579, fig. 2.

- Falcatus? Pictet and Roux. Grès Verts des Env. de Genève, t. 5, fig. 5.

A. testâ discoideâ, sub-compressâ, tuberculatâ, plerumque costatâa: anfractibus pancis sub-angulatis, lateribus depressis, tuberculatis; dorso canaliculato, utrinque bituberculato: costis bicurvatis variantibus; interdum paucis, latis, depressis; interdum ad umbilicum numerosis, dorsum versus paucis, latisque; sapé omnino obsoletis: tuberculis utrinque triserialibus, ad umbilicum simplicibus, propè dorsum binis: umbilico parvo: aperturâ rhomboideâ: septorum lobis lateralibus tribus trifidis.

Shell discoidal, flattened on the sides and back, with very few nearly rhomboidal whorls; strongly tuberculated, and frequently ribbed: back with two rows of tubercles on 
each side, and a hollow canal in the middle: ribs falcate, very variable in number and size, and, rising from tubercles on the edge of the umbilicus, they extend forward to the middle of the side of the whorl, then suddenly turn backward, and again curve forward to the dorsal tubercles; sometimes they are five in number, broad and depressed; in other specimens they are small and numerous on the inner half, and broad and few on the outer half of the whorl; frequently they are well marked on young shells, and gradually disappear with age; and in many specimens they are altogether wanting: three rows of tubercles on each side of the whorl, one at the edge of the umbilicus, and two near the edge of the back; the umbilical tubercles vary both in size and number; when there are no ribs, the tubercles are few in number, and very large; but they diminish in size, and increase in number, in proportion to the development of the ribs; the dorsal tubercles are usually large, but they vary in number from 15 to 30 , being fewest and largest where there are no ribs: umbilicus small and deep, allowing about one third of the inner whorls to be seen : aperture rhomboidal: septa with three trifid lateral lobes on each side.

Diameter, $1 \frac{1}{2}$ inch; height of last whorl, $\frac{5}{8}$ inch; width of aperture, $\frac{1}{2}$ to $\frac{3}{4}$ inch.

Found abundantly in the Chloritic Marl of the Isle of Wight; the Chalk with silicious grains at Chardstock, Somersetshire; and the junction bed of the Chalk and Upper Green Sand, near Warminster.

In the first part of this Memoir, I followed M. D'Orbigny and most other modern palæontologists in uniting together the Ammonites falcatus and curvatus of Mantell and Sowerby; but, as better materials have appeared, I have been obliged to separate them again. Both are most variable species, and there are varieties which can only be distinguished with difficulty. The only invariable distinction which I have found between them is in the termination of the superior lateral lobe, which is trifid in $A$.curvatus and bifid in A. falcatus; see PI. XXIII, figs. $1 c$ and 2. In comparing the external forms, it will be found that the more tuberculated varieties all belong to $A$. curvatus, the flatter, ribbed varieties to $A$.falcatus; but there are intermediate forms combining falcate ribs with dorsal tubercles, which can hardly be distinguished without the aid of the lateral lobe.

41. Ammonites Salteri, Sharpe. Plate XXIII, figs. 3 and 5.

A. testâ discoideâ, costatâ, tuberculatấ: costis ter-natis flexuosis, bi-tuberculatis, ad dorsum interruptis: dorso utrinque tuberculato, tuberculis alternantibus: umbilico parvo: aperturâ oblongâ : septorum lobo dorsali longissimo.

Shell discoidal, with few whorls, ornamented with ribs and tubercles on their sides: back plain, and slightly elevated in the middle, with a row of tubercles on each side; these 
are not opposite to one another, but alternate: ribs flexuous, rising in threes from twelve large tubercles which surround the umbilicus, forming an irregular zigzag pattern on the side of the whorl, and ending at twenty-four rather smaller tubercles on the side of the back : two rows of tubercles on each side of the shell : umbilicus small, allowing about one third of the inner whorls to be seen: aperture oblong: septa with the dorsal lobe considerably longer than the trifid superior lateral lobe.

Found by Mr. Wiest, in the Chalk with silicious grains, at Chardstock, Somersetshire.

42. Ammonites Ramsayands, Sharpe. Plate XXIII, fig. $4 a-c$.

A. testâ discoideâ, costatâ, tuberculatâ: anfractibus paucis, sub-compressis: costis continuis, bi-tuberculatis, ad dorsum bifurcantibus : dorso lato, rotundato, costato, utrinque tuberculato : umbilico parvo : aperturá oblongâ.

Shell discoidal, with few, slightly flattened whorls, and a broad, rounded back: the whorls are ornamented on the sides by twenty ribs, each of which rise from a small tubercle at the edge of the umbilicus, and bear another larger tubercle near the back; at the latter tubercle each rib divides into two smaller ribs, which continue across the back, and unite again at the corresponding tubercle on the other side of the back: umbilicus small, allowing nearly half of the inner whorls to be seen: aperture oblong: the septa have not been seen.

Diameter, $1 \frac{1}{2}$ inch; height of the last whorl, $\frac{5}{3}$ inch; width of the aperture, $\frac{1}{2}$ inch.

Very rare in the Chalk with silicious grains, at Chardstock, Somersetshire.

The only specimen which has been seen of this species is deformed, owing, without doubt, to an accident met with when very young. In consequence of this malformation, the two sides have very little resemblance to each other; and the specific character given above may prove incorrect when more perfect specimens are met with.

A. Ramsayanus belongs to the group of the Coronarii, which, for the most part, belong to the lower and middle divisions of the Oolitic series: its nearest congeners are perhaps A. Humphriesianus and A. Brackenridgii. It is the second species of that group which has been found in the Chalk; $A$. catinus having been the first.

This species is named after Professor Ramsay, of the Geological Survey of Great Britain.

\section{larizhoplites}

43. Ammonites Feraddianus, $D^{\prime} O r b$. Plate XXIII, fig. $6 a-c$.

["A. testâ compressâ, transversim costatâ : costis incqualibus, rectis; dorso complanato, 
laleraliter angulato, anfractibus compressis, sub-quadrilateralibus, ultimo $\frac{38}{100}$; aperturá oblongâ, antice truncatâ."”-D'Orbigny, 'Terr. Crét.,' t. i, p. 324.

The species thus described by M. D'Orbigny, in 1840, was said to have been discovered by M. Emeric in the "Craie Chloritées" at Vergons, Basses-Alpes; but in a later work, the 'Prodrome de Paléontologie,' t. ii, p. 98, it is referred to the "Néocomien supérieur ou Urgonien."

'The specimen figured in Plate XXIII, fig. 6, was obtained by Mr. Sharpe from the Grey Chalk at Ventnor, in the Isle of Wight, and named by him "Feraudianus;" but as no memorandum exists to support this identification, it might possibly have been changed, as it rests upon a single, crushed, and immature specimen.]

44. Ammonites Bravaisianus, D’Orb. Plate XXIII, figs. $7 a, b, 8$, and 9.

Ammonites Bravaistanus, D’ Orbigny. Paléontologie Française, Terrains Crétacés, t. 91, figs. 3 and 4.

A. testấ compressấ, carinatấ, costatấ: costis incequalibus, simplicibus vel bifurcatis, dorsum versus bituberculatis, interruptis: dorso carinato; carinâ elevatâ, acutâ: umbilico magno : aperturá oblongâ.

Shell discoidal, with few depressed whorls, which are ornamented by about thirty transverse, slightly flexuous ribs: back keeled: the ribs are unequal, either simple and alternately long and short, or occasionally branching in pairs from the edge of the unsbilicus; each rib terminates at the side of the back, where it is ornamented with two smaller tubercles: keel distinct, sharp, and elevated : umbilicus large, allowing two thirds of the inner whorls to be seen: aperture oblong.

Diameter, 1 inch ; height of last whorl, $\frac{3}{8}$ inch; width of aperture, $\frac{1}{3}$ inch.

Found in a hard bed of the Middle Chalk, near Dover. In France it has been found in the Upper Green Sand of the department of Vaucluse.

This pretty little Ammonite has some resemblance to A. varians, from which it is at once distinguished by the pair of tubercles at the termination of each rib. Moreover, its ribs are simpler than in that species, and never fork on the middle of the side of the whorl. As yet A. Bravaisianus has only been found in this country in one bed of rather hard Chalk, which occurs near the bottom of the Chalk with Flints, and contains $A$. peramplus, Scaphites, and several other species of Mollusca hitherto undescribed, and only known in that bed. 
45. Ammonites Wiltonensis, Sharpe. Plate XXIII, fig. $10 a-c$.

[A. testâ compressâ, transversim costatâ, costis parvis, numerosis, obtusis, incequalibus ; aperturâ elongatâ, antice rotundatá ; umbilico parvo. Lat. maj., 13 ; min., 11 ; alt., 6 lines.

This figure is taken from a small Ammonite in hard, gritty Chalk, with green stains, stated to have been found near Devizes, by Mr. W. Cunnington. The form is unusual in the Chalk; the ribs are simple, and sub-equal on the back of the shell, but many become obsolete on the sides, the remainder becoming stronger at the umbilicus; the sutural lobes are few and rather simple.]

\section{Guedryceres}

\section{6. Аммоnites Jukrsil, Sharpe. Plate XXIII, fig.'11 $a-e$.}

[A. testâ discoideâ, late umbilicatâ, transversim costatấ; costis numerosis, acutis; anfractibus sub-compressis, interdum constrictis; aperturâ ovatâ.

This specimen figured is the fragment of an Ammonite which, when perfect, probably measured 5 or 6 inches in diameter; it consists of about one third of the external volution and portions of two inner whorls, which have been detached, and represented separately (fig. $11 b, c$ ). The curvature of the ribs is convex towards the aperture; but the figures are not only reversed, but placed upside down. The outer whorl shows one of the periodic constrictions, and another is seen on the inner whorl when detached, and also a more prominent rib on the posterior side of the constriction.

Ammonites Jukesii was discovered by Colonel Portlock, R.E., in the hard Chalk of the county of Londonderry.]

\section{Genus-Ap'Trchus, H. Von Meyer. 1821.*}

The operculum [or calcarious plates presumed to have closed the aperture] of certain species of Ammonites, of which there are three forms distinguished by Voltz:

1. Cornei, consisting of a single horny plate, of a semi-circular, semi-elliptic, or truncato-ovate form, marked by concentric wrinkles, with a semi-circular notch on the middle of the straight side.

2. Imbricati, consisting of a pair of equal plates, each a quarter of a circle, or quarter

* The name Trigonellites, given by Parkinson, who described and figured several forms in 1811 ("Org. Rem.,' iii, 184), ought to have been employed. Meyer added nothing to our knowledge respecting then. 
of an ellipse, in form, marked on one or both sides by strong concentric lines or wrinkles, produced by the imbricated growth of the shell; each plate has a fold along its straight side, the fold of one plate lapping over that of the other: the plates usually thin.

3. Cellulosi, consisting of a pair of plates, similar in form to those of the Imbricati, and meeting in the same manner, but thick, and with the convex side cellular in structure.

Few organic remains have given rise to more different opinions than these curious bodies. [Professor Quenstedt regards them as the opercula of Ammonites, a view which has been generally adopted in Germany. See Woodward's 'Manual,' 1851, p. 80, and Owen's 'Lectures on the Invertebrata,' 2 d edit., 15.55, p. 596. In Part I, p. 19, of this Monograph, the concave side of the Aptyclucs is incorrectly stated to have been external instead of the convex side.]

All the Aptychi yet found in the Chalk belong to the group of the Imbricati; they have all very thin shells, owing to which they are seldom found perfect; and they are all from the Upper or Middle Chalk.* As there is now little doubt that these bodies really belong to some part of Ammonites, I have endeavoured to assign them to their respective species of Ammonites, in which I have been guided by a comparison of the form and size of the Aptychi with the apertures of the Ammonites found in the same beds of the Chalk Formation, and in the same localities, for I am not aware that any Ammonite has yet been found in the Chalk containing an Aptychus within it. As there are but few species of Ammonites known in the Upper and Middle Chalk, the comparison is more satisfactory than might have been anticipated; but the result is only conjectural, as the discovery of other species of Aptychus or of Ammonites might materially alter our conclusions on this subject.

The species of Ammonites known in the Upper and Middle Chalk are A. Griffithii and A. Oldhamii, only known in Ireland, whence I have seen no Aptychi; for which they are excluded from the comparison.

A. Gollevillensis," found in the Upper Chalk in Ireland and the North of France, and which may consequently be expected to occur here.

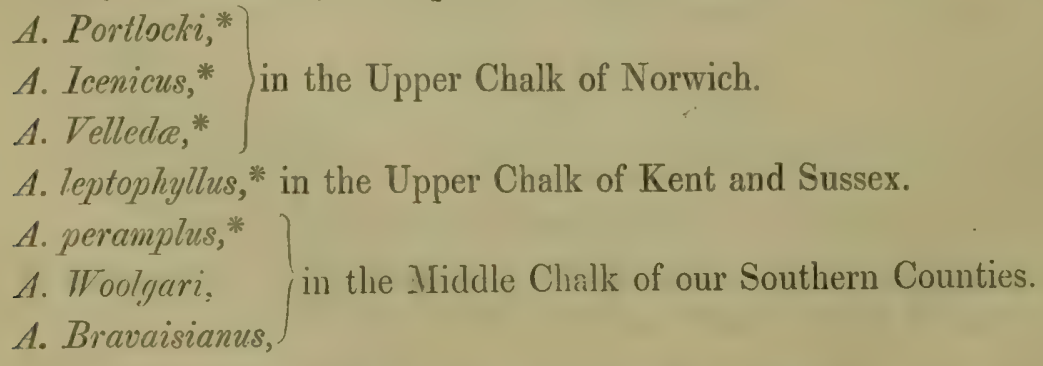

The species marked * have round backs, and belong to Von Buch's family of Ligati. 1. Woolyari has a serrated keel, and belongs to the Rothomagenses; A. Bravaisianus

* Mr. Flower has also found two species in Flint Pebbles in the Gravel, near Croydon. 
has a sharp keel, and may be excluded from the comparison, as it is too small to admit any of the Aptychi yet found.

As yet we have only seven forms of Aptyclus from the Chalk, six of which have so many characters in common, that it is natural to suppose that they belong to Aminonites of the same, or nearly allied groups; the remaining species, $A$. rugosus, differs in having the convex side strongly ribbed.

In Plate XXIV, which is deroted to this subject, are represented all the known Aptychi of the Chalk, and outlines of the openings of the varions Ammonites to which it seems probable that the Aptychi may belong; and, to facilitate the comparison, a dotted line is drawn across each opening. It must be remembered that the two plates of the Aptychi did not lie flat in the same plane, but were slightly inclined towards one another [on the inner side], in which position the width they occupied would be rather less than when they are represented lying side by side on the plate.

Among the Aptychi belonging to the Chalk, figured by Continental authors, Aptychus cretaceus, of Münster, so nearly approaches several of those which are here described, as to show that they belong to nearly allied Ammonites. But sad confusion has been made with that specific name. Geinitz gives three figures of Aptychus cretaceus ('Charakteristik des Sächsischen Kreidegebirges,' t. 17, figs. 25 $a$ and $b$ and 26), which evidently belong to three different species; another distinct species is figured under the same name by Reuss ('Versteinerungen der Böhmischen Kreideformation,' t. 7, fig. 13), and both these authors refer to Aptychus cretacens, the plate described under the name of Anatifa converu, by Roener ('Kreidegebirges,' t. 16, fig. 7), which, if the figures are to be trusted, diffie's from all the others.

A ptychos leptophyllos, Sharpe. Plate XXIV, fig. $1 a, b$.

A. livalvis, subtruncato-ovatus; valvis imbricatis, latere convexo lavi, latere concuvo concentricè lineato; plicâ mediâ inconspicuâ.

Bivalve, thin, the united valves orate, with a slight truncation at the lower end; outer edge reflected : the convex side smooth; the concave side delicately marked by very close, concentric imbrications : medial fold narrow, and but little elevated.

Height, $1 \frac{1}{2}$ inch; breadth of each valve, $\frac{1}{2}$ inch.

Found in the Upper Chalk, near Brighton, by Mr. Morris.

The form of this Aptychus corresponds to that of the opening of Ammonites leptopliyllus: and which is also found in the Upper Chalk, near Brighton; for these reasons it is probable that it belongs to that species. 
Aptrchus Pontlocki, Sharpe. Plate XXIV, figs. 2, 3, and 4 (6?)

A. bivalvis, transversim semi-ellipticus; valvis imbricatis, utrinque concentricè sulcatis; sulcis distantibus; plicâ mediâ elevatá.

Bivalve, the united valves forming, transversely, a semi-ellipse, with a uniform curve to the outer margin; valves thin, marked on both sides by rather distant concentric furrows, produced by the terminations of the broad imbricated additions to their outer edges : medial fold large, and separated from the rest of the valve by a deep furrow.

Height, $\frac{3}{4}$ inch ; breadth of each valve, $\frac{1}{2}$ inch.

Found in the Upper Chalk, near Norwich, by Mr. Bayfield; and in a Flint Pebble, in the Gravel, near Croydon.

Of the Aptychi yet met with in the Upper Chalk, this species has the transverse diameter of its united valves greatest in proportion to its height; and Ammonites Portlocki is the only species known in the Upper or Middle Chalk which has the diameter of its mouth greater than its height (see Plate XXIV, fig. 12). Moreover, the curves of the respective outlines of the two nearly correspond, and both are found in the Upper Chalk, near Norwich. The probability of this Aptychus belonging to A. Portlocki is therefore very strong.

One of the three forms figured by Geinitz under the name of Aptychus cretaceus ('Charakteristik, \&c., des Sächsischen Kreidegebirges,' t. 17, fig. 25 a) nearly resembles A. Portlocki in outline, but, being a fragment, its proportions are not shown; and it is distinguished by its closely set imbrications from our species.

Anatifa convexa, Roemer, 'Kreidegeb.', t. 16, fig. 7, is the plate of an Aptychus closely approaching A. Portlocki; but his figure and description do not enable me to identify them.

Aptychus Gollevillensis, Sharpe. Plate XXIV, fig. 5.

A. bivalvis, truncato-ovatus; valvis imbricatis, utrinque concentricè sulcatis; sulcis approximatis : plicá mediâ elevatá.

Bivalve, truncato-ovate, the united valves forming about two thirds of the shape of an egg; very convex, especially towards the outer edges: valves thin, marked on both sides by closely set concentric furrows, produced by the terminations of the narrow imbricated additions to the outer edges: medial fold elevated, and sharply separated from the rest of the valve by a deep furrow. 
Height, $\frac{5}{8}$ inch; breadth of each valve, $\frac{3}{8}$ inch.

Found in the Upper Chalk of Norwich, by Mr. T. G. Bayfield, and in Flint Pebbles in the Gravel, near Croydon.

Of the Ammonites found in the Upper Chalk, the one of which the outline of the mouth most nearly resembles this Aptychus is A. Gollevillensis (Pl. XXIV, fig. 15). I have not seen this species of Anmonite from Norwich; but as, besides being found in the North of Ireland, it occurs in France, in the Upper Chalk of the department of the Manche, it may be expected to occur also on our side of the Channel; so that it is probable that the Aptychus here described belongs to Ammonites Gollevillensis.

Of the varieties of Aptychus cretaceus figured by Geinitz, one form (l.c., t. 17, fig. $25 b$ ) approaches our species, but does not admit of absolute identification with it.

Aptrchus Icenicus, Sharpe. Plate XXIV, fig. $7 a, b$.

A. bivalvis, ovalis; valvis imbricatis: latere convexo rugis paucis, latis, longitudinalibus, inconspicuis, ornato: plicâ mediâ parvá.

Bivalve, very thin; oval, with nearly straight sides: valies very convex, especially towards the lower end: the convex side faintly marked by a few broad, longitudinal folds, which are not parallel to one another, and which cross the imbrications : medial fold small and straight: the concave side has not been seen.

Height, $\frac{5}{8}$ inch; breadth of each valve, $\frac{1}{4}$ inch.

Found in the Upper Chalk, near Norwich, by Mr. T. G. Bayfield.

Ammonites Icenicus is the only species yet seen from the Upper Chalk which has its opening corresponding to the peculiar outline of this Aptychus, which has its sides nearly straight, and its two extremities nearly equal; and as both are found in the Upper Chalk, near Norwich, there is every probability that they must be counected.

Aptrchus rugosus, Sharpe. Plate XXIV, figs. $8 a, b$, and 9.

[A. bivalvis, truncato-oblongus; valvis imbricatis, latere convexo corrugatis, plicis distantibus, elevatis, tuberculatis, anticè angulariter inflectis.

Bivalve; together oval or oblong, and notched at each end; separate plates nearly flat, thin, finely imbricated by lines of growth on the concave side, and ornamented with elevated wrinkles on the outer surface; ridges from $\frac{1}{2}$ line to 1 line apart, irregularly tuberculated, sub-parallel with the outer margin, and bent back at a sharp angle at the upper end; slightly irregular and flexuous, and becoming obsolete near the suture. 
Ileight of largest specimen (fig. 9), $2 \frac{1}{4}$ inches; breadth of single valve, 11 lines. Small pair (fig. 8), height, $1 \frac{1}{4}$ inch ; breadth, 1 inch.

From the Upper Chalk of Norwich, in the collections of Mr. John King and Mr. T. G. Bayfield.]

Aptychos peramplus, Sharpe. Plate XXIV, fig. $10 a, b$.

A. bivalvis; truncato-ovatus? valvis imbricatis, latere converco corrugatis, latere concavo subtiliter concentricè lineatis: plicâ mediâ elevatâ.

Bivalve; truncato-ovate? valves imbricated, thin near the medial fold, thicker towards the edge; convex side corrugated, the corrugations covered with irregular and unequal tubercles; concare side marked by fine concentric lines, indicating the edges of the closely set imbrications : medial fold large.

From the Chalk, near Norwich, in the collection of Mr. Bayfield.

I have only one fragment of this Aptyclus, $1 \frac{1}{2}$ inch in breadth, and can offer but an imperfect description of it: the convex side is concealed in the specimen, and the direction of the corrugations cannot be seen. It is with great hesitation that I propose to connect it with Ammonites peramplus.

[This specimen was described by Mr. Bayfield in ISø̃l ("Annals and Magazine of Natural History,' 2d series, vol. viii, p. 236), being the first instance on record of the occurrence of Trigonellites in the English Chalk.]

Since the preceding descriptions of the species of Aptychus were in type, a memoir* has appeared on the Cretaceous Fossils of Meudon, France, by M. Ed. Hébert, in which three species of Aptychus are described; A. obtusus, crassus, and insignis, the last form being closely allied to, if not identical with, $A$. rugosus, above noticed.

* Mém. Soc. Géol. de la France, vol. v, p. 367, pl. 28. 
Genus-TURRILITES, Lamarck. 1801.

Animal unknown : shell chambered, turreted, usually sinistral, with numerous angular whorls, twisted spirally round a central cavity, and contiguous throughout on their upper and lower sides: chambers separated by transverse, flexuous septa, deeply sinuated towards the edges, and divided into six branching lobes, which are unsymmetrical, those on the outer side of the whorls being much larger than the corresponding lobes on the inner side: spire traversed by a continuous tube, situated on the outer side of the whorl, a little below the suture: mouth of the adult shell produced downwards, and bent over somewhat into the form of a hood.

The genus Turrilites, as it has been usually receired, includes, in addition to the shells here classed in it, other chambered, turreted species, with contiguous, rounded whorls, and the siphuncle placed on the middle of the outer side of the whorl. I have rentured to remove these species to the genus Helicoceras, with which they agree in the round form of their whorls, and in the position of their siphuncle, and only differ in having their whorls contiguous instead of separate. The importance of that difference is destroyed by our finding a species with rounded whorls, Helicoceras or Turrilites polyplocus, Rocmer, in which the whorls are separate during the early part of their growth, contiguous in their next stage, and again separate when full grown; in consequence of which it has been moved from one to the other genus, according to the part of the spire which was described. M. D'Orbigny had already pointed out that there were two very distinct groups of Turrilites, and assigned their characters-1st, the rotundati, which are those which I propose to unite to Helicoceras; $2 \mathrm{~d}$, the angulati, which form the genus Turrilites, as here retained.

The produced, arched mouth has not yet been seen in all the Turrilites, but there are indications of it in so many species, that it may be presumed to be universal in the genus. I can find no evidence that this mouth was formed more than once during the life of the animal, as is conjectured by M. D'Orbigny ('Terr. Crét.', p. 570); on the contrary, we find that, before the mouth is produced, there is always some modification in the form of the ribs which would betray the previous position of the produced mouth, if such had existed and had been absorbed by the animal; but no specimens show any such irregularity of the ribs in any of the upper whorls, so that we must conclude that the month was only produced once, and the different size of individuals of the same species on which this occurs only show that some reached their adult form sooner than others.

There is very little difference in Turrilites betreen their forms and ornaments in the young and older stages of their growth, excepting near the produced mouth; so that the species may be recognised in specimens of any size or age. 
None of the group of the rotundati have been found with the produced mouth like the Turrilites, and the only modification known in the adult shells of that group is a thickening of the edge of the mouth: probably this will be found to be another generic difference between Turrilites and Helicoceras.

\section{Classification of Turrilites.}

1. Rotondat, D'Orb. Whorls round; siphuncle near the middle of the exterior side of the whorl; ribs simple; mouth thickened.

Common in the Gault.

T. acuticostatus, D’Orb。 C. C.

2. Angulati, D'Orb. Whorls angular; siphuncle near the suture; mouth covered with a hood.

$2 a$. Lateral lobe trifid; ribs or tubercles not arranged in regular lines across the whorl.

T. tuberculatus, Bosc. L. Chalk.

T. Gravesianus, D’Orb. Pl. 144, fig. 3. L. Chalk.

T. Mantelli, Sharpe.

$2 a$ a. Lateral lobe trifid; tubercles in regular rows across the whorl.

T. Bergeri, Brong. Gault and L. Chalk.

2 2. Lateral lobe bifid; tubercles or ribs arranged in regular lines across the whorl.

T. catenatus, D'Orb. Pl. 140, fig. 1. Gault.

T. Puzosianus, D’Orb. Pl. 143, fig. 1. Gault.

T. Scheuchzerianus, Bosc. L. Chalk.

T. costatus, Lam. L. Chalk.

T. Wiestii, Sharpe. L. Chalk.

2c. Lateral lobe bifid; tubercles not in regular rows across the whorl.

T. Morrisii, Sharpe. U. G. Sand and L. Chalk. 
1. Turrilites tuberculatus, Bosc. Plate XXV, figs. 1 to 4 , and Pl. XXVI, figs. $15,16$.

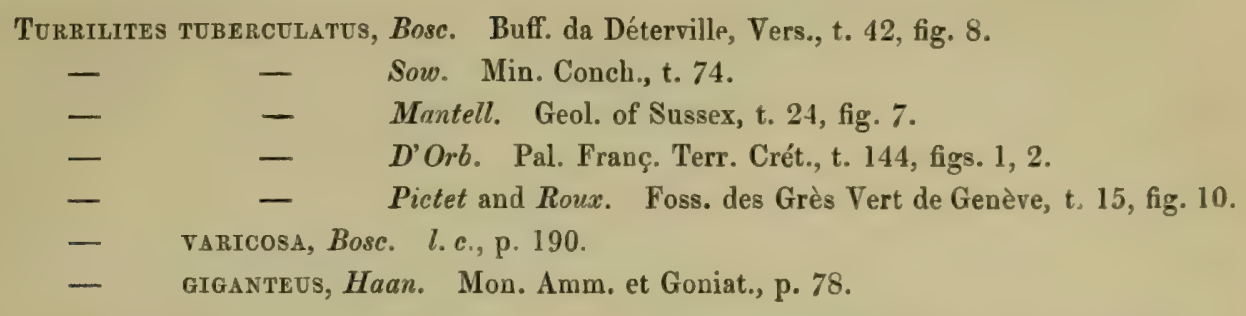

T. testâ turritâ, sinistrorsâa : anfractibus numerosis, extrâ convexis, tuherculato-spinowis : tuberculis 4-serialibus; serie superiori, in medio anfractuum, tuberculis 20 distantibus, maximis, spinosis; seriebus tribus inferioribus propé suturam tuberculis parvis, numerosis, approximatis: angulo spirali $16^{\circ}-20^{\circ}$.

Shell turreted, with a spiral angle of $16^{\circ}$ to $20^{\circ}$, sinistral : whorls numerous, rounded externally, with one row of above 20 very large spinose tubercles near their middle, and three rows of numerous small tubercles near their base, the lowest of which three rows is concealed by the suture; the tubercles of the middle row have a rounded base, those of the three lower rows are elongated in a direction parallel to the suture, and are of the same number in each row : upper and lower sides of the whorls ornamented with faint, radiating ribs, corresponding to the tubercles of the lowest row: umbilicus narrow: section of the whorls nearly rhomboidal, with the outer side convex : mouth somewhat produced, and rising to a blunt point on the inner side of the whorl, and surrounded by a wing-shaped expansion, with a nearly semicircular outline.

'The figures 1 and 4 represent the usual form of this species, with nearly twice as many tubercles in the lower rows as there are in the upper one; but specimens are often found like fig. 3 , with less difference between the different rows in the size and number of the tubercles, and with the two lower rows of tubercles almost coalescing. I have seen no specimen in which these two varieties are found in the same individual, as is represented in M. D'Orbigny's fig. I; but as the lobes of the septa of the two forms closely correspond, we must presume that they belong to the same species. In very large individuals the tubercles of the upper row are fewer in number, and proportionably larger.

The lobes of the septa are much divided and branching; the outer side of the whorl holds half of the dorsal lobe, the dorsal saddle, and half of the superior lateral lobe, which last has five principal branches; the dorsal saddle is divided into two nearly equal parts, and each of these is divided into two nearly equal branches (fig. 15). 'This is the character by wiich I. tuberculatus is best distinguished from T. Gravesianus, which has the dorsal saddile divided into two very unequal parts, only the upper of which is again divided.

The larger specimens of Turrilites are never found perfect, so that their length must be 
calculated. The specimen of this species figured in the 'Mineral Conchology' has a diameter of 5 inches in the lower whorl, and must have been above 18 inches long. The common-sized specimens have their largest diameter about $2 \frac{1}{2}$ inches, and probably reached 9 or 10 inches in length.

Common in the Grey Chalk of the South of England, and in the Chloritic Marl of the Isle of Wight, and the Chalk with siliceous grains, of Dorset and Somerset.

2. Turrilites Gravesianus, D’Orbigny. Plate XXV, fig. 7, and Plate XXVI, fig. 14.

Turrilites Gravesianus, D'Orb. Pal. Franç. Terr. Crét., t. 144, figs. 3-5.

- tuberculatus, Mantell. Geol. of Sussex, t. 24, fig. 6.

T. testâ turrito-conicâ, sinistrorsâa: anfractibus paucioribus, extrâ angulato-convexis, tuberculato spinosis: tuberculis 4 serialibus; serie superiore, in medio anfractuum, tuberculis 10-12 maximis, spinosis, distantibus; seriebus tribus inferioribus propé suturam tuberculis parvis, numerosis, approximatus; angulo spirali $30^{\circ}$.

Shell conical, with a spiral angle of about $30^{\circ}$, sinistral: whorls few, externally convex, and somewhat angular in the middle, with one row of 10 or 12 very large spinose tubercles a little above their middles, and three rows of numerous small tubercles near their base; the two lowest of these rows are so near together that the tubercles almost coalesce, and are partially concealed by the suture; the tubercles of the upper row have a rounded base, those of the other three rows are elongated in a direction parallel to the suture, and are of the same number in each row : upper and lower sides of the whorls ornamented with radiating ribs, corresponding to the tubercles of the lowest row : umbilicus narrow : section of the whorls somewhat pentagonal: the perfect mouth has not been seen.

The lobes of the septa are much divided, and form a very complicated pattern; the dorsal lobe, dorsal saddle, and nearly two thirds of the superior lateral lobe are visible on the outer side of the whorl; the latter has four principal branches, of very unequal size : the dorsal lobe is short; the dorsal saddle is very large, and unevenly divided, the upper half having two principal branches, of which the upper ends in three, the lower in two terminal branchlets; the lower half of the dorsal saddle has only one undivided straight branch, parallel to the siphuncle: this peculiarity in the dorsal saddle distinguishes the species from T. tuberculatus; the superior lateral lobe is very large, and is divided into five large branches (Plate XXVI, fig. 14).

Diameter of the largest whorl, $1 \frac{3}{4}$ inch ; presumed length, 5 inches.

Rare in the Grey Chalk, near Lewes, and in the Chloritic Marl of Ventnor, Isle of Wight.

The external form of this species is very similar to that of $T$. tuberculatus, with which 
it was long confounded. M. D'Orbigny pointed out the distinctions between them, which consist in the shorter and blunter spire, fewer and larger tubercles of T. Gravesianus. Slightly crushed specimens of T. tuberculatus are sometimes very difficult to distinguish from T. Gravesiames, nnless the outline of the septa can be traced, when the different forms of the dorsal saddles set all doubts on the subject immediately at rest.

\section{Turriultes Mantelui, Sharpe. Plate XXV, figs. 5 and 6.}

T. testâ turritâ, sinistrorsấ: anfractibus numerosis, extrâ convexis, tuberculatis : tuberculis 4 serialibus; serie superiori, in medio anfractuum, tuberculis 20-24, basi rotundatis; seriebus tribus inferioribus, tuberculis 30 minoribus, basi elongatis, approximatis: anguls, spirali $18^{\circ}-20^{\circ}$.

Shell turreted, with a spiral angle of $18^{\circ}$ to $20^{\circ}$, sinistral: whorls numerous, convex externally, with one row of 20 to 24 tubercles near their middle, and three rows of about 30 smaller tubercles near their base, the lowest of which rows is hid by the suture; the tubercles of the middle row have a rounded base, those of the three lower rows are elongated in a direction parallel to the suture, and are of the same number in each row : upper and lower sides of the whorls ornamented with radiating ribs, corresponding to the tubercles of the lower row : umbilicus narrow : mouth somewhat produced, and rising to a blunt point on the inner side of the whorl, and surrounded by a broad, wing-shaped expansion of somewhat rhomboidal form.

Only a small part of the outline of a septum has been seen, which is shown on the upper whorl of fig. 5 ; the dorsal saddle is divided into two unequal parts, which are intermediate in form between those of $T$. tuberculatus and $T$. Gravesianus, more nearly. resembling the latter.

Diameter of last whorl, $2 \frac{1}{2}$ inches; probable length, 12 inches.

Rare in the Grey Chalk, near Lewes, Sussex.

This species is readily distinguished from $T$. tuberculatus by the greater number and smaller size of the tubercles of the upper row, which are almost as numerous as those of the three lower rows. There is also a marked difference in the rhomboidal form of the expanded margin of the mouth. These distinctions will probably be strengthened when a more complete view is obtained of the lobes of the septa.

The only specimens which I have seen were collected by Dr. Nantell, and are now in the British Museum. 'The specific name is therefore a just tribute to the memory of that zealous geologist. 


\title{
4. Turrilites Scheuchzerianus, Bosc. Plate XXVI, figs. 1-3.
}

\author{
Turrilites Schevchzriands, Bosc. Buffon du Deterville, vol. $\vee$, p. 190. \\ - undulatus, Sow. Min. Con., t. 75, figs. 1-3. \\ - $\quad$ Mantell. Fossils of the South Downs, t. 23, figs. 14 and 16; t. 24, \\ fig. 8. \\ - $\quad$ - Geinitz. Kreide, t. 13, figs. 1-3. \\ - $\quad$ - D'Orb. Paléont. Franç. Terr. Crét., t. 146, figs. 3, 4. \\ - Desnoyersi, D'Orb. Paléont. Franç. Terr. Crét., t. 146, figs. 1, 2.
}

T. testâ turritâ, sinistrorsâa : anfractibus numerosis, extrâ rotundatis, costatis : costis mumerosis, sub.angulatis; junioribus interruptis; adultis continuis: angulo spirali $15^{\circ}-18^{\circ}$.

Shell turreted, with a spiral angle of $15^{\circ}$ to $18^{\circ}$, sinistral : whorls numerous, rounded externally, crossed by 20 to 24 sharp, elevated ribs; on the upper whorls the ribs are nearly straight, and broken into two unequal parts by a depression a little below their middle; towards the middle of the shell the depression gradually disappears, and on the lower whorls the ribs continue uninterruptedly across the whorl, and become more and more flexuous : upper and under sides of the whorls smooth : umbilicus very small : mouth produced considerably downwards, partially arched over, and expanded towards the umbilicus: the outline of the septa has not been seen.

Diameter of last whorl, $1 \frac{3}{4}$ inch; estimated length, 8 inches.

Common in the Grey Chalk, wherever that bed occurs, in the South of England.

This species is so well distinguished from all the other Turrilites by its elongated form and comparatively simple ribs, that it had remained free from all confusion, until M. D'Orbigny unfortunately proposed the specific name of $T$. Desnoyersi for its young form, and gave an appearance of probability to his suggestion by representing both the young and the old forms as full grown shells on his plate 146, without any variation in the ribs during the growth of either.* Such errors are the natural consequence of what is called restoring the entire form of a shell from a fragment, instead of representing what is actually seen. Dr. Mantell had already given an admirable figure of a nearly perfect specinen, exhibiting the change from the broken ribs of the upper whorls to the unbroken ribs of the older whorls, which ought to have preserved M. D'Orbigny from this unnecessary addition of a synonym.

Figure 2 represents a young shell, with ribs still divided, which is already beginning

* Figures 1 and 3, plate 146, are both stated to be "restauré sur un échantillon de ma collection." D'Orb., 'Terr. Crét.,' vol. i, pp. 602 and 604. 
to form a mouth like an adult, with the ribs becoming flexuous. A still younger shell, with the produced mouth completed, is shown in fig. 3 ; but as this specimen has the lower side of the whorl strongly ribbed, it may be doubted whether it belongs to the same species.

\section{Torrilites Morrisil, Sharpe. Plate XXVI, figs. 4-S.}

T. testâ turritâ, sinistrorsấ: anfractibus numerosis, extrâ plrniusculis tuberculatis: tuberculis 3 vel 4 serialibus; serie superiori, in medio anfractuum, tuberculis 8-12 majoribus, distantibus; seriebus inferioribus propé suturam, tuberculis minoribus, numerosis: angulo spirali $15^{\circ}$.

Shell turreted, with a spiral angle of about $15^{\circ}$, sinistral: whorls numerous, nearly flat externally, with one row of 8 to 1.2 large tubercles near their middle, and two or three rows of above 20 smaller tubercles near the suture, all of them with a round base: upper and lower sides of the whorls ornamented with faint, radiating ribs, corresponding to the tubercles of the lowest row: umbilicus very narrow : section of the whorls rhomboidal: septa with the superior lateral lobe bifid, with four branches on each side, and the dorsal saddle divided into two very unequal parts: the perfect wouth has not been seen.

In the young shell the three lower rows of tubercles are usually distinct; in older shells the tubercles of the two lower rows gradually coalesce, and at last hardly more than one row can be distinguished, close to the suture.

Largest diameter, $1 \frac{1}{4}$ inch; probable length, 6 inches.

Common in the Chloritic Marl of the Isle of Wight, and in the Chalk with siliceuts grains, Chardstock, Somersetshire.

\section{Turrilutes Brrgeri, Brongniart. Plate XXVI, figs. 9-11.}

Turrilites Bergeri, Brong. Env. de Paris, t. 7, fig. 3.

- - D'Orb. Pal. Frauç. Terr. Crét., t. 143, figs. 3-6.

T. testâ turritâ, sinistrorsẩ (vel dextrorsẩ?) : anfractibus paucioribus, rotundatis, tuberculatis: tuberculis 4 serialibus, aquidistantibus, aqualibus : aperturä rotundato-rhomboideâ.

Shell turreted, turned to the left: whorls not very numerous, increasing rapidly in size, rounded, and ornamented with four equidistant rows of numerous, rounded tubercles, which are of the same number, and nearly the same size in each row ; only three rows are 
cxposed, the upper one being covered by the next whorl; the tubercles are so placed as to appear to form sloping, transverse bands across the whorls : section of the whorls somewhat rhomboidal : septa, and position of the siphuncle, unknown.

Spiral angle about $35^{\circ}$.

Diameter of the largest specimens from Chardstock, in Mr. Wiest's collection, 3 iuches.

This is a well-marked shell, which can hardly be confounded with any other species. We have not met with any specimen turned to the right like that figured by M. D'Orbigny, t. 143 , fig. 6 .

Abundant in the Chalk with green grains, at Chardstock. (Mr Wiest.)

7. Turrilites BechiI, Sharpe. Plate XXVI, fig. 13.

1. testâ turritâ, sinistrorsấ: anfractibus pancioribus, extrâ rotundatis, costatis, tuberculatisque: costis numerosis, superioribus, flexuosis, tenuibus, infrä interruptis: tuberculis biserialibus, inferioribus, numero costarum aqualibus: angulo spirali $30^{\circ}$.

Shell turreted, sinistral, with a spiral angle of $20^{\circ}$ : whorls few, externally rounded, prettily ornamented with numerous delicate, flexuous ribs, which extend from the suture across the upper two thirds of the whorl, where they are interrupted by a smooth space, in which are two rows of tubercles, elongated in the direction of the suture, and equal in number to the ribs; below these the ribs appear again, bending backwards over the lower side of the whorl ; thus each rib, with its corresponding pair of tubercles, forms a flexuous line across the outer and the under sides of the whorl: umbilicus small : the outline of the septa has only been partially seen; the dorsal saddle is divided into two slightly unequal parts : the specimen figured shows the beginning of a produced mouth.

Diameter of last whorl, 1 inch; estimated length, 4 inches.

Only one specimen has been seen, which was found in the Chalk with siliceous grains, near Lyne Regis, by Sir H. T. de la Beche, and by him presented to the British Museum : it is named in honour of his memory.

8. 'l'urkilites costatus, Lamarck. Plate XXVII, figs. $1-5$, and 15, 16 .

Turrilites costatos, Lamk. 1801. An. sans Vert., p. 102.

- - Sowerby. 1813. Min. Conch., t. 36.

- $\quad$ - Brong. 1822. Env. de Paris, p. 83, t. 7, fig. 4.

- - Mantell. 1822. Geol. of Sussex, t. 23, fig. 15.

- - D’Orbigny. Paléont. Franç., Terr. Crét., t. 145.

- triplicatos, J. Sow. In Dixon's Geol. of Sussex, t. 29, fig. 16. 
T. testá elongato-turritâ, sinistrorsâ, costatá et tuberculatâa; anfractibus conrexius culis, inferné costatis, superné bituberculatis; costis tuberculisque nunero aqualibus; aperturi ovali; umbilica minimo.

Shell turreted, turned to the left, with a spiral angle of about $25^{\circ}$; whorls slightly convex, separated by a moderately impressed suture, and ornamented on their lower half by numerous straight, elevated ribs, which rise at their upper ends into round tubercles, and then terminate abruptly at a smooth spiral band, which encircles the shell; above are two rows of tubercles, the upper of which are smaller, and concealed by the next whorl; ribs and tubercles equal in number; aperture oval, higher than broad; umbilicus very snall.

[The complicated form of the septa in this species is represented in Pl. XXVII, fig. 15.]

In Dixon's 'Geology of Sussex,' a Turrilite is described under the name of T. triplicatus, J. Sow., which appears to be a variety of the abore. [This specimen is figured in Pl. XXVII, fig. 15.]

Found in the Chalk Marl of Ventnor, Isle of Wight; and in the Chalk with green grains, at Chardstock.

\section{Turritutes birrons? D' Orb. Plate XXVII, figs. $6, \pi$.}

[T. testâ turritâ, elongatâ, sinistrursấ; anfractilus convexiusculis, sulco longitucinaliter ornatis; transversim costatis: costis curvatis, interruptis, biseriatis, anteriorilis ad suturam dirisis.

The specimens figured differ from the ordinary examples of $T$. costatus in the flattening of the whorls, occasioned by the shallow furrow which divides the curved transverse ribs into a double series: the ribs are simple, rounded, and about as wide as the interspaces; the lower series of ribs is again divided by a furrow exactly at the suture, forming a third set of little tubercles, only visible on the base of the shell when broken.

Found in the Lower Chalk, of Ventnor, Isle of Wight.]

10. Terrilites WiestiI, Sharpe. Plate XXVII, fig. $8,9 a, b$, and fig. 17 .

T. testâ turritâ, sinistrorsá; anfractibus externis rotundatis, tuberculatis, intus lactibus: tuberculis conicis 4 serialibus, numero equalibus, superiore et inferiore minoribus, in suturá profundâ crenulatâ, coalescentibus, mediis binis majoribus prominentibus; aperturî́ subquadratá; umbilico parvo.

Shell turreted, tuberculated; spine turned to the left, with a spiral angle of about $22^{\circ}$ : whorls rounded, separated by a deep, crenulated suture, ornamented with four rows of conical tubercles, which are of the same number in each row, and set obliquely under one 
another, without ribs between them; the tubercles of the two outer rows are smaller than the other's, and meet at the junction of the valves, forming a crenulated suture; while the tubercles of the two middle rows, which are nearly equal, are prominent on the side of the whorls; surface of the whorls between the the tubercles smooth; aperture nearly square; umbilicus small.

The largest specimen seen has a diameter of $1 \frac{1}{4}$ inch, which requires a length of 4 or 5 inches.

As yet we have only seen it from the Chalk with green grains, where it is very abundant.

'This elegant shell is at once distinguished from T. tuberculatus by having the same number of tubercles in each row, in which it agrees with T. Bergeri. From this it differs in the shape of the whorl, and the position of the lower row of tubercles, which is at the suture instead of projecting at the side of the whorl : in consequence of this, it has only two rows of tubercles visible instead of three on the side of the whorl.

Found in the Grey Chalk, of Ventnor, Isle of Wight; and also in the Chalk with green grains, at Chardstock, Somersetshire; and at Chaldon and Man-nf-War Cove, Dorsetshire.

\section{1. 'Turrilites Puzosianus, D’Orb., var.? Plate XXVII, fig. 11. \\ ? Turrilites Puzosianus, D’Orbigny. Terr. Crét., pl. 143, figs. 1, 2.}

1. testâ turritâ, sinistrorsấ; anfractibus externi planiusculis, costulatis, tuberculatis; custis mumerosis, flexuosis, obliquis, supernè internuptis tuberculatisque; tuberculis bi-serialilus., seriis superioris binis, inferior is longitudinaliter compressis; aperturä ovali; umbilico parvo.

Shell turreted; spine turned to the left, with a spiral angle of about $15^{\circ}$; whorls flattish, with the lower angle rounded off, separated by a moderate suture, and ornamented with numerous oblique, flexuous, slight ribs, interrupted near the top of the whorl by a smooth spiral band, on each side of which the ribs rise into longitudinally flattened tubercles; the tubercles of the upper row bifid or double, and stand at the angle of the whorl; aperture somewhat oval; umbilicus small.

I have as yet only seen one fragment of this shell. It resembles T. Puzosianus, D'Orb., in having rils rising into tubercles on each side of a smooth band, which, rumning round the upper part of the whorl, divides the ribs into two unequal parts. Our shell differs from T. Puzosiamus in the flexure of the ribs, and in the position of the upper row of tubercles, which. in that species, is placed at the suture, and thus concealed by the next whorl; but in this one it is at the upper angle of the whorl, and always prominent. It differs from T. costatus in the flexure of the ribs and flatness of the whorls.

Found in the Chloritic Marl, of Bonchurch, Isle of Wight. 


\section{PLATE I.}

Fig.

1, 2, and 3. Belemitella mucronata; from the Upper Chalk, near Norwich.

1. Ventral view, with the fissure.

$2 a$ and $b$. Dorsal and lateral views of a specimen, in which the vascular impressions are well seen.

2c. Alveolus from above.

3. Section of another specimen, showing the eccentric position of the alveolus, and traces of the edges of the septa.

4, 5, and 6. Beleirnitella Lianceolata; from the Upper Chalk, near Norwich.

$4 a, b$, and $c$. Dorsal, lateral, and ventral views of one specimen.

4d. Alveolus from above.

5. Ventral view of a young specimen.

6. Section of another specimen, showing the central alveolus.

7. Belemnitella quadrata; from the Middle Chalk of Kent, in the collection of

Mr. J. G. Lowe; this specimen is broken at the top.

7a. Dorsal view.

76. Side view.

7c. Portion of the granulated surface, magnified.

8. Belemitella Quadrata; from the Middle Chalk of Kent, in the collection of Mr. Bowerbank.

8a. Dorsal view, showing the two lateral depressions.

8b. The alveolar opening slightly broken away at the edges.

9. Belemnitella qdadrata; a young specimen from the Upper Chalk of Northfleet in the collection of Mr. Morris, with the two vascular impressions strongly marked.

9a. Dorsal view.

9b. Lateral view.

10. Belemitella quadrata; alveolar opening from above, perfectly preserved. In the collection of $\mathrm{Mr}$. Bowerbank. 
Fig.

11. Belemnitella quadrata; from the collection of Mr. Bowerbank.

$11 a$. Section, showing the conical form of the lower part of the alveolar opening, and the fissure.

11b. The same, enlarged.

12, 13, 14, 15, and 16. Belemnitella Plena; from the Grey Chalk, near Dorking.

12a. Dorsal view.

12b. Upper end, with the lower part of the alveolus preserved.

13. A young specimen.

14. Section of a specimen, from which the alveolus is entirely broken off.

$1 \check{a} a$. Dorsal view of a specimen, broken off at the apex of the alveolus.

15b. Broken end of the last.

16. Section of a young spécimen.

17. Belemnites oltimus ; from the Chloritic Marl of Bonchurch in the Isle of Wight, in the Collection of Mr. Saxby.

$17 a$. Side view.

17b. Ventral view.

17c. Outline of the opening. 


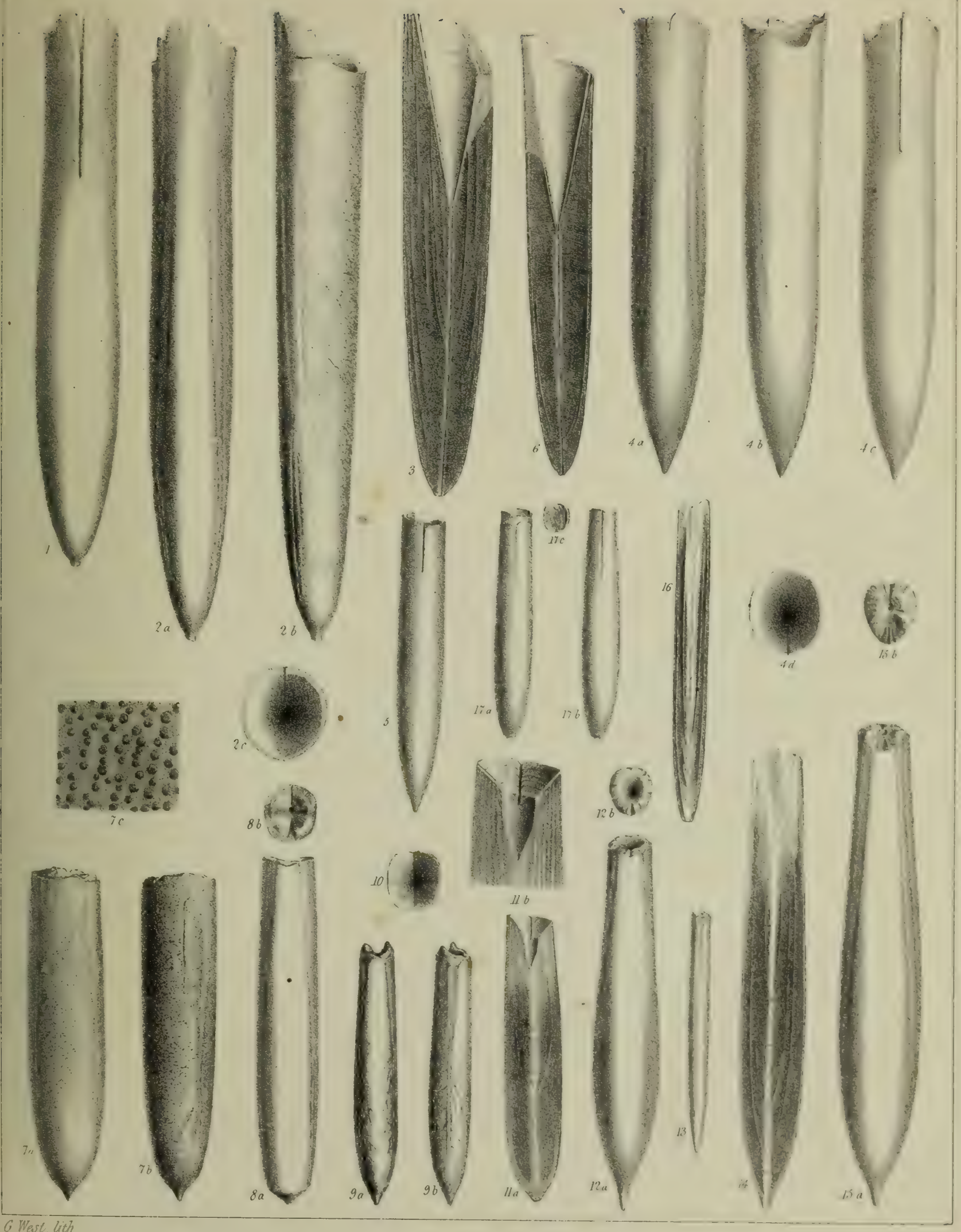






\section{PLATE II.}

Fig.

1. Nadtilus Levigatus; from the Chalk with siliceous grains of Chardstock, in the collection of Mr. Wiest.

1a. Side view.

1b. Front view.

2. Nautilus Lævigatus, young; from the Chloritic Marl of Bonchurch, in the collection of Mr. Saxby.

2a. Side view.

2b. Front view, showing the position of the siphuncle.

3. Nadtirus expansus; from the Chalk with siliceous grains of Chardstock, in the collection of Mr. Wiest.

3a. Front view.

$3 b$. Side view.

4. Nautilus expansus, young; from the Chalk, with siliceous grains of Chardstock, in the collection of Mr. Weist.

4a. Side view.

4b. Front view.

4c. Portion magnified, showing the cross striation.

5. Nautulus expansus; view of one septum, showing the position of the siphuncle; from Mr. Bunbury's collection. 

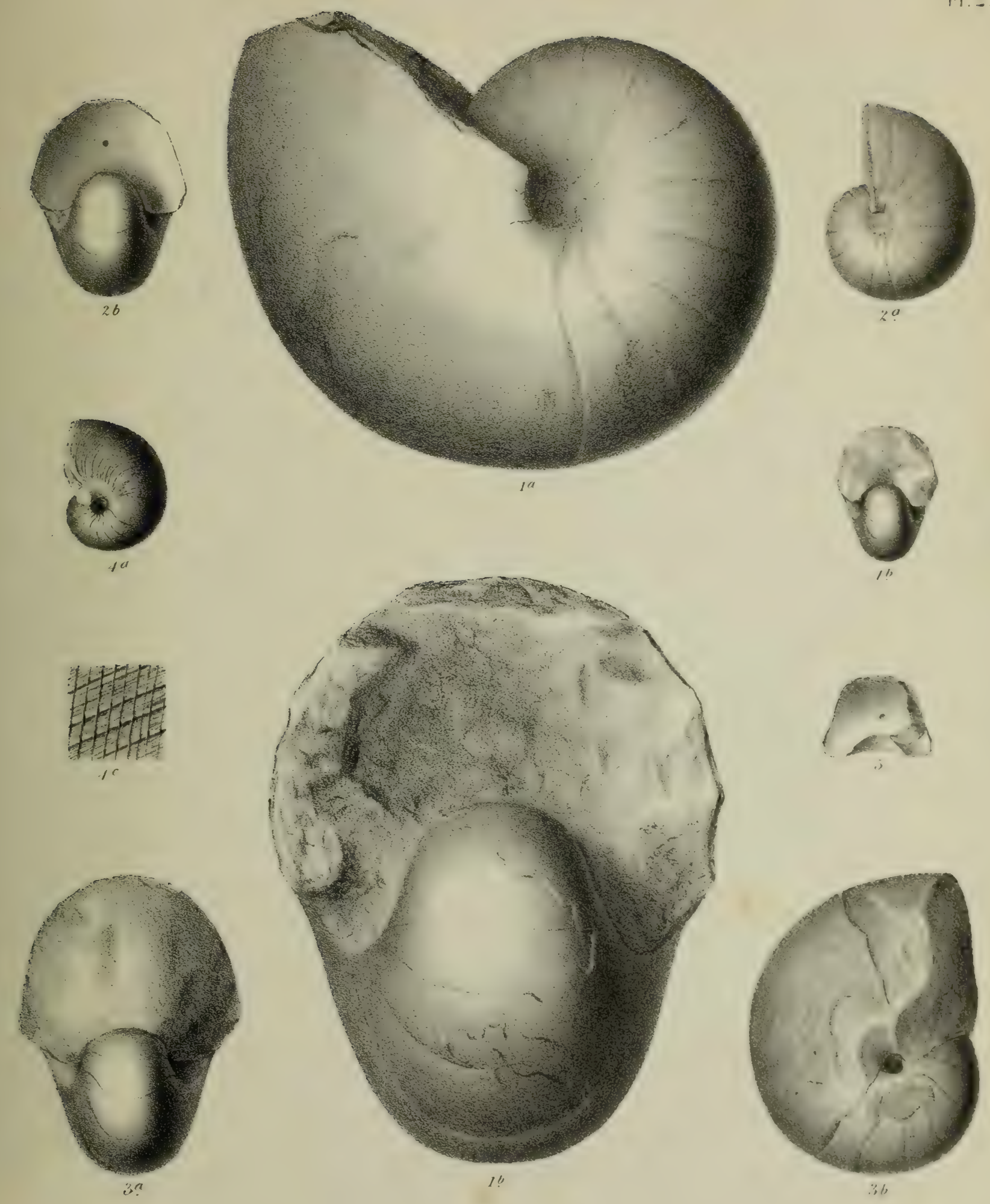




\section{PLATE III.}

Fig.

1. Nautilus Deslongchampsianus; from the Grey Chalk near Lewes, in the collection of Dr. Mantell.

1a. Side view.

1b. Back view.

2. Nautilus Deslongchampsianus; a fragment somewhat crushed, with the cross-ribbing well preserved. From the Grey Chalk, near Lewes.

3. Nautilus Elegans; from the Grey Chalk near Lewes, in the collection of Mr. Hudson.

The smooth part of this specimen has been enclosed in another whorl, which is partially broken away. 
11.:
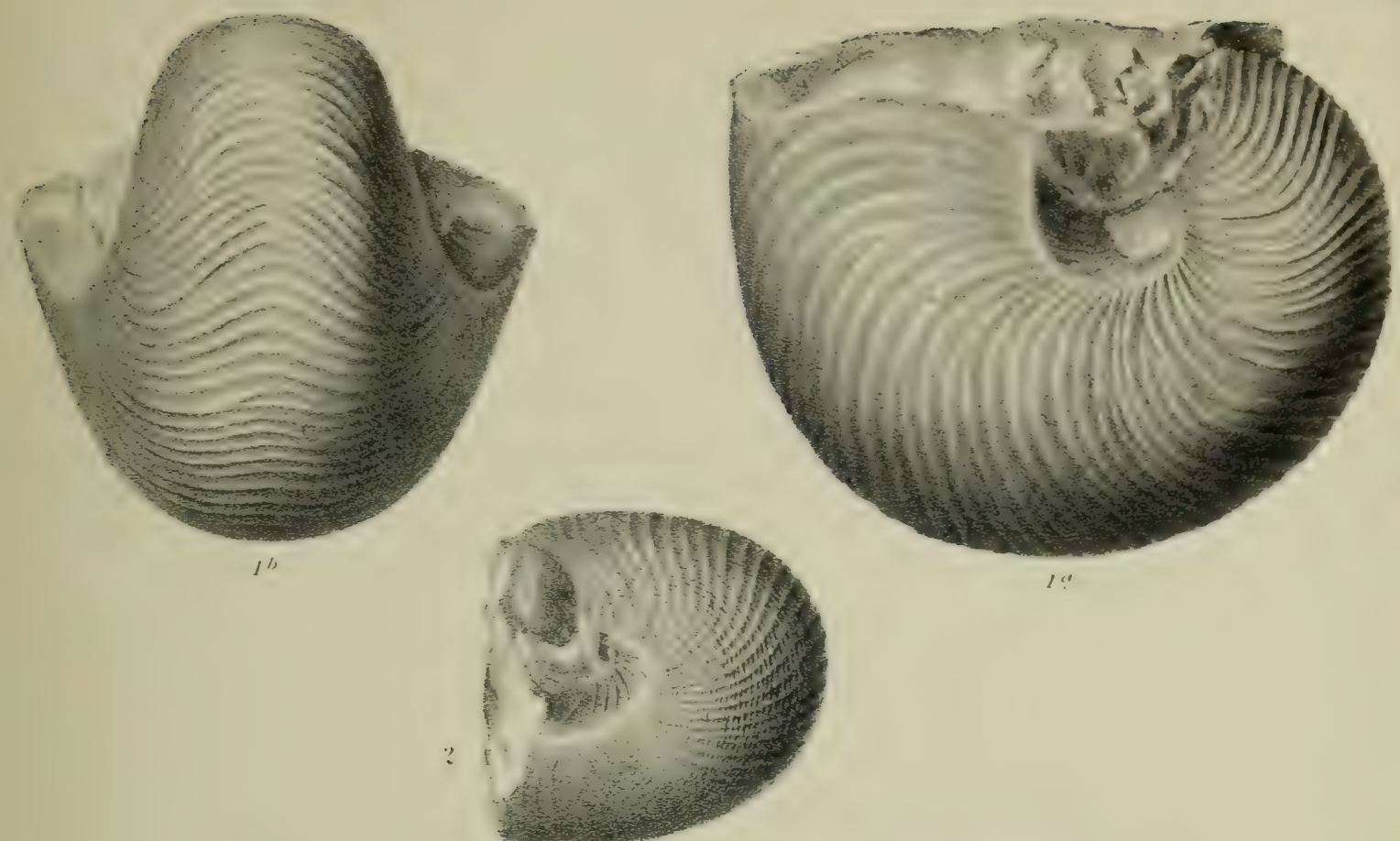

I!

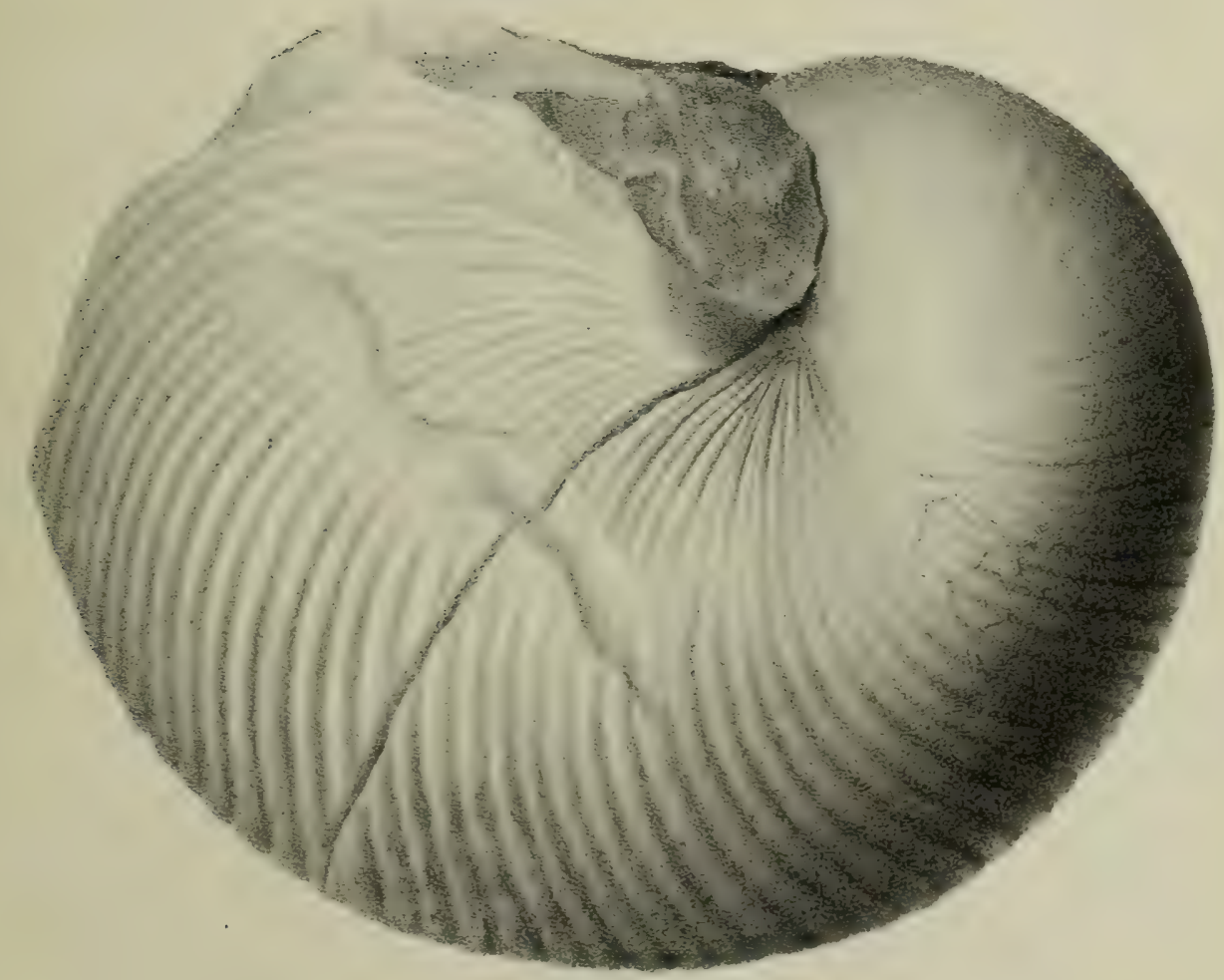

i) 




\section{PLATE IV.}

Fig.

1. Nautrlus elegans, reduced to two thirds; a front view of the inner portion of the specimen figured Plate III, fig. 3, showing the position of the siphuncle.

2. Nautilus pseudo-elegans; from the Grey Chalk near Lewes, in the collection of the Geological Society.

2a. Side view.

2b. View of one septum, with the opening for the siphuncle. 


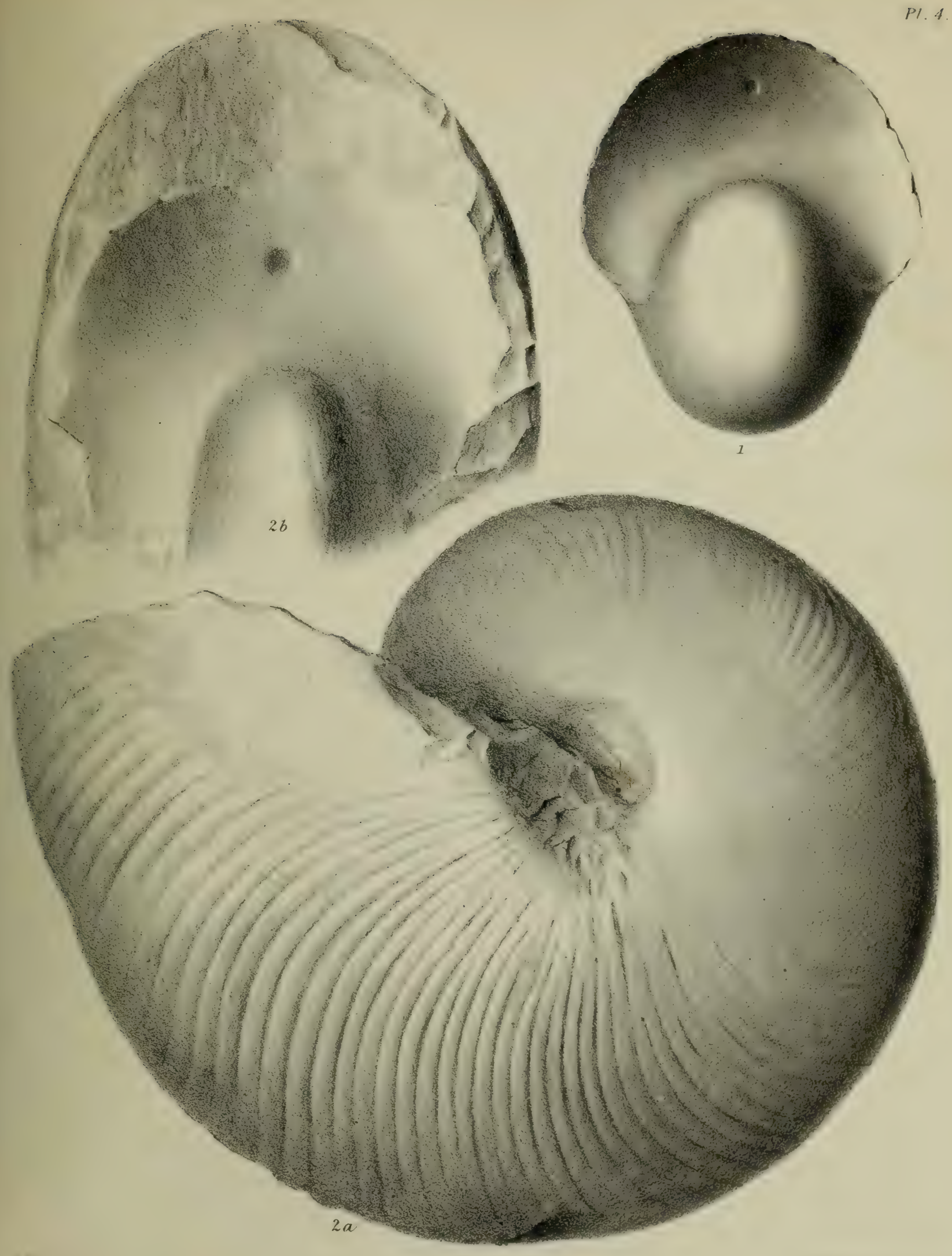






\section{PLATE V.}

Fig.

1. Nautilus Radiatus; from the Chalk with siliceous grains of Chardstock, kindly given me by Mr. Wiest.

1a. Side view.

1b. Front view, showing the position of the siphuncle, and the ventral depression on the septum.

2. Nautilus radiatus; young specimen, with a portion of the cross-striation of the young shell preserved. From the Chalk with siliceous grains of Chardstock, in the collection of Mr. Morris.

3. Nautilus Neocomiensis; from the Grey Chalk of Urchfont near Devizes, in the collection of Mr. Cunnington.

$3 a$. Side view.

36. Back view.

3c. Septum showing the position of the siphuncle.

4. Nautilus undulatus; from the Chalk with siliceous grains of Chardstock, in the collection of Mr. Wiest.

4a. Side view.

4b. Front view.

4c. Septum showing the position of the siphuncle. 

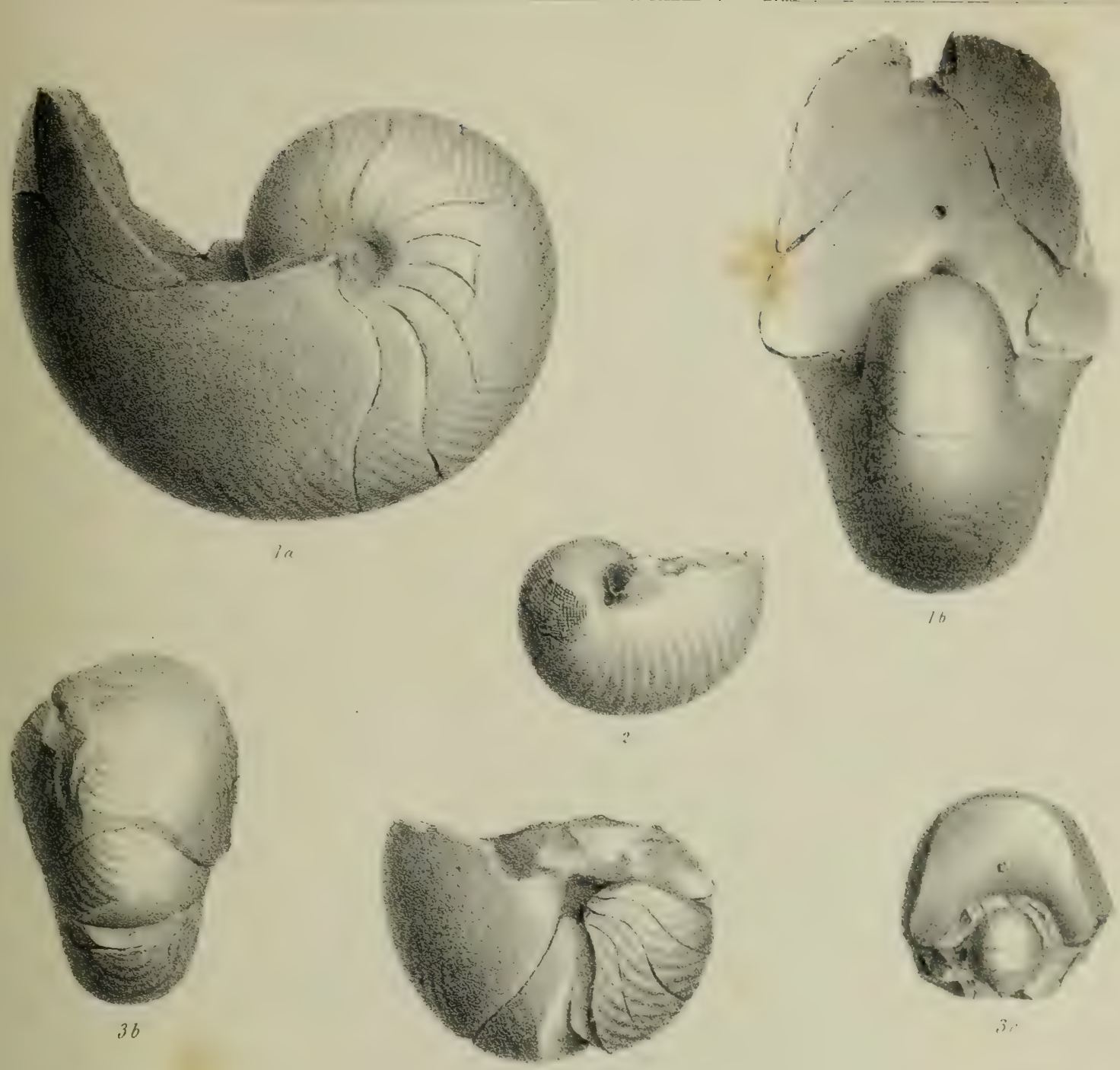

$3 b$
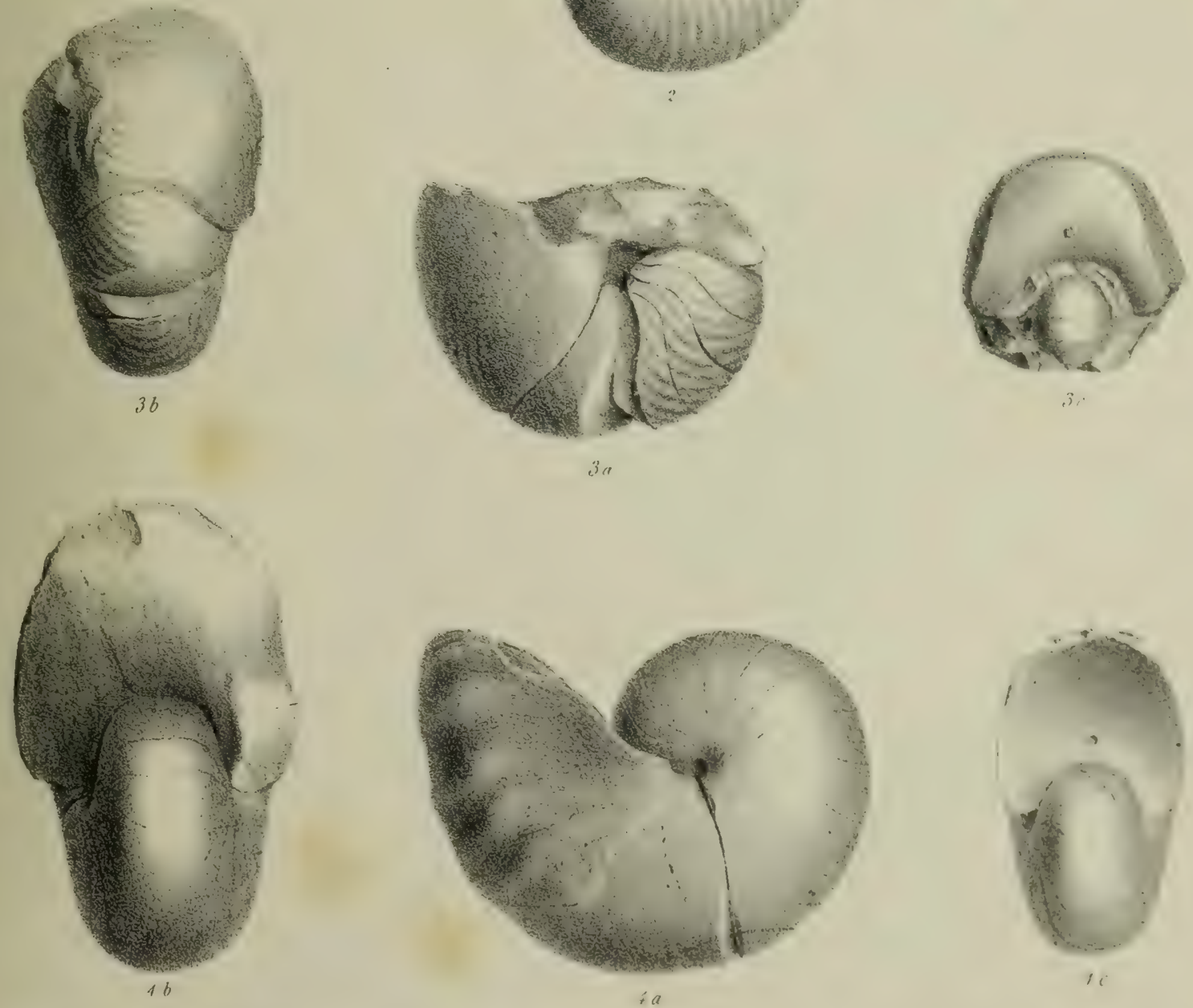




\section{PLATE VI.}

Fig.

1. Nautilus largilliertianus; from the Chalk with siliceous grains of Chardstock, in the collection of Mr. Wiest.

1a. Side view.

1b. Front view.

2. Nautilus largilliertianus; a fragment from the Chalk with siliceous grains of Chaldon, in the collection of Mr. Morris.

$2 a$. Side view, with a commencement of undulation on the back.

2b. Septum, showing the position of the siphuncle.

3. Nautilus Fledriausianus ; from the Chalk with siliceous grains of Chardstock, in the collection of Mr. Wiest.

$3 a$. Side view.

3b. Front view.

4. Nautilus Fitroni; from the Chalk with siliceous grains of Chardstock, in the collection of Mr. Wiest.

4a. Side view.

4b. Back view.

4c. Septum showing the position of the siphuncle. 

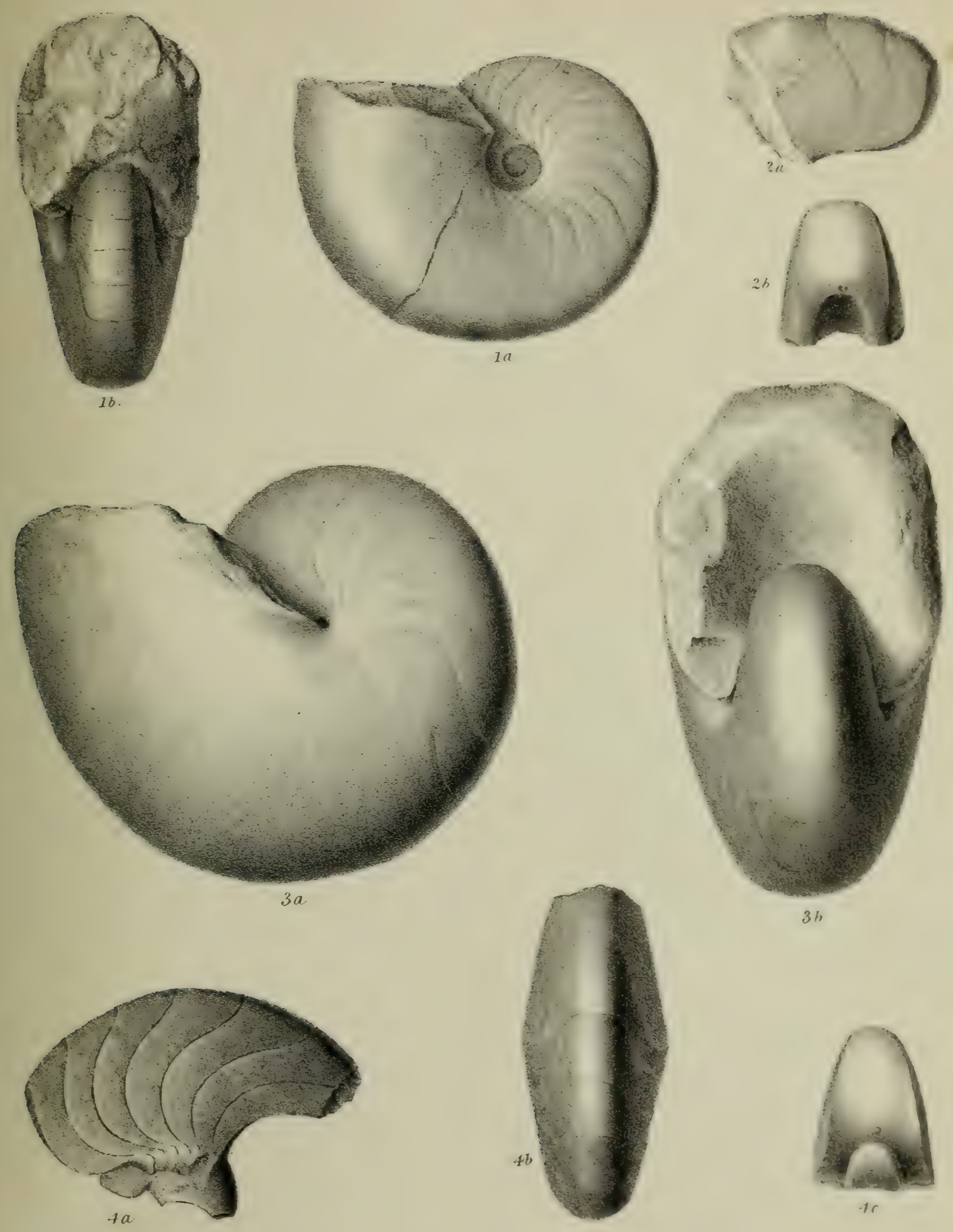




\section{PLATE VII.}

Fig.

1-3. Ammonites complanatus.

1. From the Grey Chalk of Hamsey; in the British Museum, from the collection of Dr. Mantell; the original specimen figured, t. 569, of the 'Mineral Conchology,' reduced to half its diameter.

1a. Side view.

16. Front view.

2. A young specimen of the natural size; in the British Museum, from the collection of Dr. Mantell.

3. Outline of the margin of a septum, copied from pl. xcv of the 'Paléont. Française Terrains Crétacées.'

$d l$. The dorsal lobe.

$s l l$. The superior lateral lobe.

ill. The inferior lateral lobe.

a $a$ a. Auxiliary lobes.

$s d$. The dorsal saddle.

$l s$. The lateral saddle.

$t$. The position of the siphuncle on the middle of the back.

4. Ammonites oвтестUs; from the Chalk with siliceous grains of Chardstock, in the collection of Mr. Wiest.

4a. Side view.

4b. Front view.

4c. Portion of the outline of a septum, only extending to the lateral saddle.

5-9. Ammonites falcatus.

5. From the Grey Chalk of the Clayton Tunnel, on the Brighton Railway, in the collection of Mr. Catt.

$6 a$ and $b$. From the Chloritic Marl of Gore Cliff, Isle of Wight, in the collection of Mr. Saxby.

$7 a$ and $b$. A specimen in the collection of Mr. Morris, from the Chalk with siliceous grains of Chaldon.

$8 a$ and 6 . From the Chloritic Marl of Bonchurch, Isle of Wight; in the collection of $\mathrm{Mr}$. Saxby.

9. Outline of a septum of a young specimen. 
II. II]

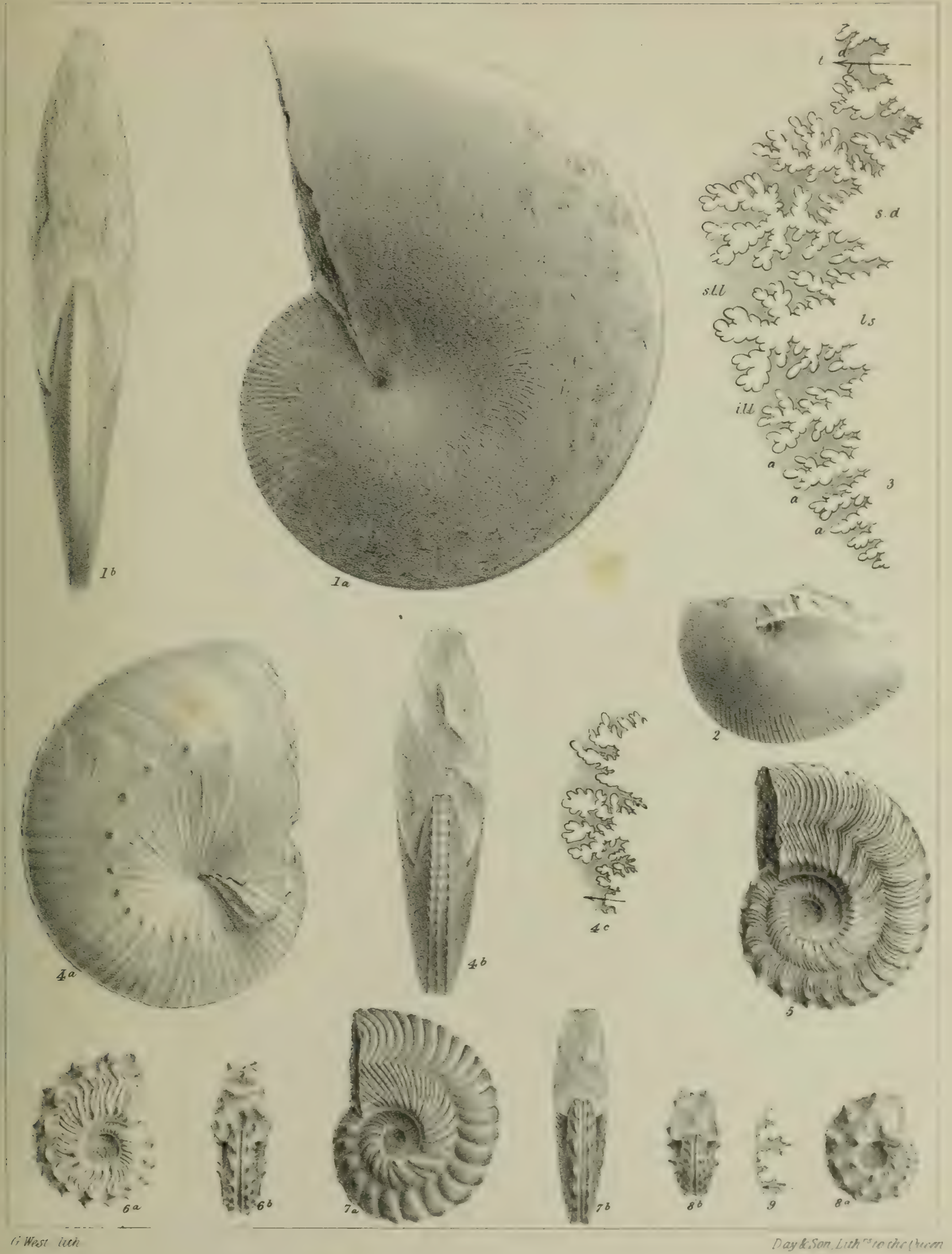






\section{PLATE VIII.}

Fig.

1-4. Ammonites Coopei.

$1 a$ and $b$. Tuberculated variety; from the Chloritic Marl of Bonchurch, Isle of Wight, in the collection of Mr. Saxby.

$2 a$ and $b$. Commonest of the species; from the Chalk with siliceous grains of Chardstock, in the collection of Mr. Wiest.

2c. Outline of the septum of a young specimen of the tuberculated variety.

3. Outline of the septum of the specimen, fig. $2 a$.

4. Tuberculated variety, young; from the Chalk with siliceous grains of Chardstock, in the collection of Mr. Morris. The lateral tubercles have been partially rubbed off.

5-10. Ammonites varians.

var

$5 a, b$, and $c$. Common form of the species; from the Chalk with siliceous grains of Chardstock, in the collection of Mr. Morris.

$6 a$ and $b$. Broken specimen of the same variety as fig. 5 , showing the form of the shell when young; from the Chalk with siliceous grains of Chaldon, in the collection of Mr. Morris.

$7 a$ and $b$. Ribbed variety with obsolete lateral tubercles; from the Chalk with siliceous grains of Chardstock, in the collection of Mr. Morris.

$8 a$ and $b$. Another variety; from the Chalk with siliceous grains near Lyme Regis.

$9 a$ and $b$. Smooth variety; from the Chalk with siliceous grains of Chardstock, in the collection of Mr. Wiest.

$10 a, b$, and $c$. Young specimen of a smooth variety; from the Chloritic Marl of Bonchurch, Isle of Wight. 

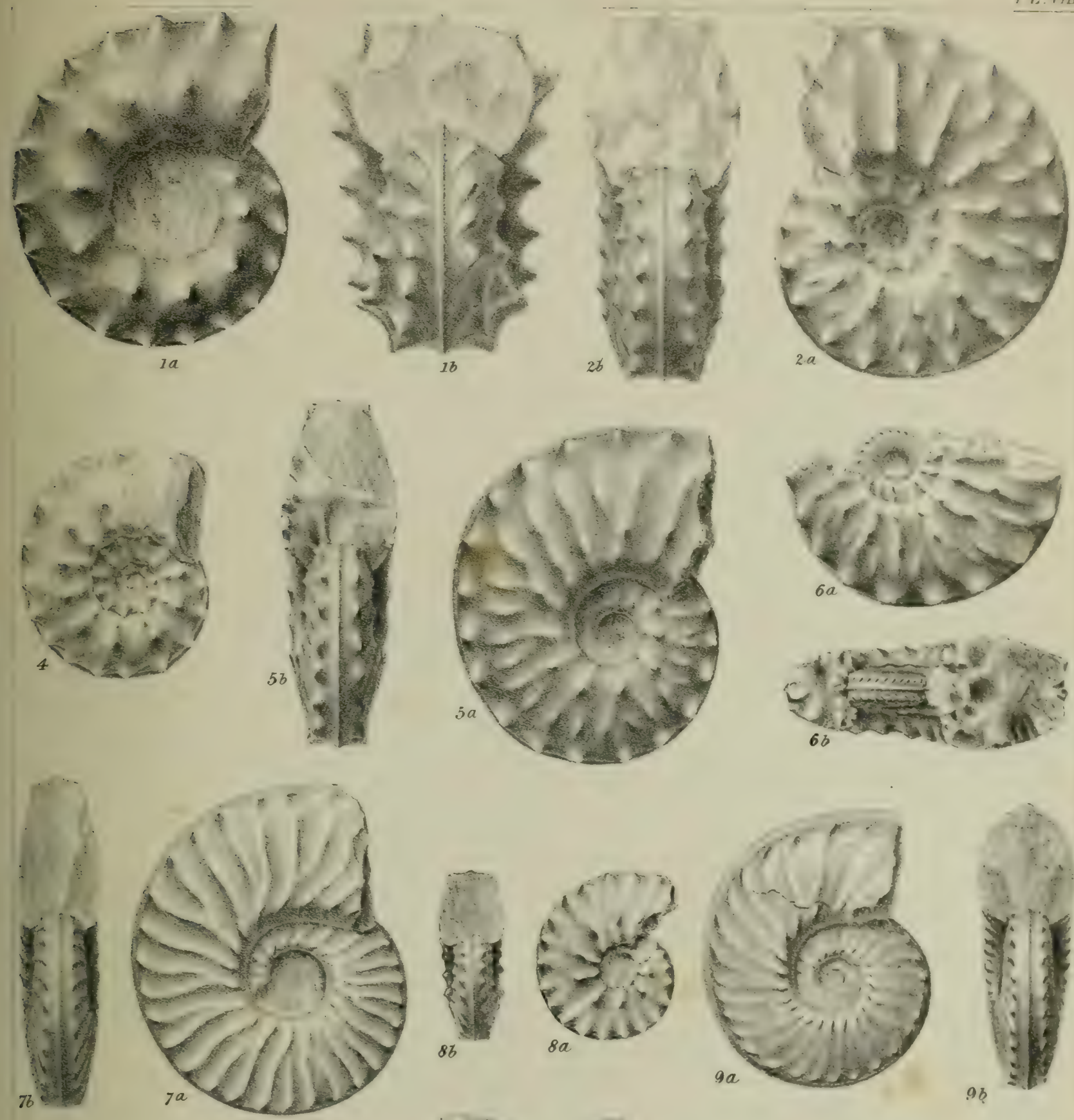

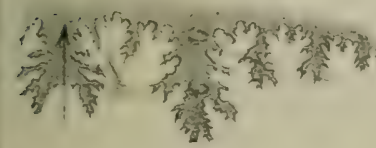
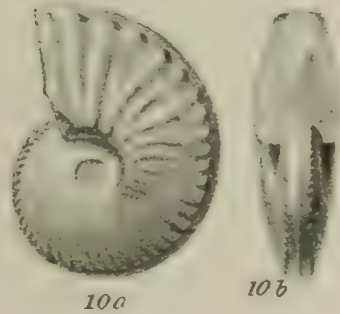

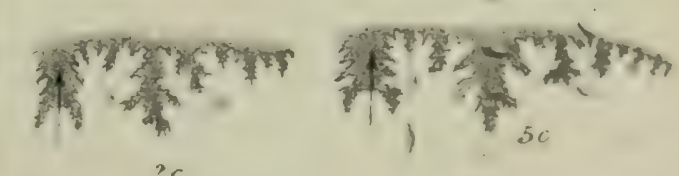
100

$$
2 r
$$






\section{PLATE IX.}

Fig.

$1 a$ and $b$. Ammonites Coupei ; from the Grey Chalk near Devizes, in the collection of Mr. Cunnington.

$2 a$ and $b$. Ammonites cinctus; from the Grey Chalk of Middleham, in the British Museum, from the collection of Dr. Mantell : the original specimen described by Dr. Mantell, and figured in the 'Mineral Conchology,' pl. 564.

$3 a, b$, and $c$. Ammonites Bunburianus; from the Chalk with siliceous grains of Chardstock, in the Museum of Practical Geology, from the collection of $\mathrm{Mr}$. Bunbury. 
II $/ X$
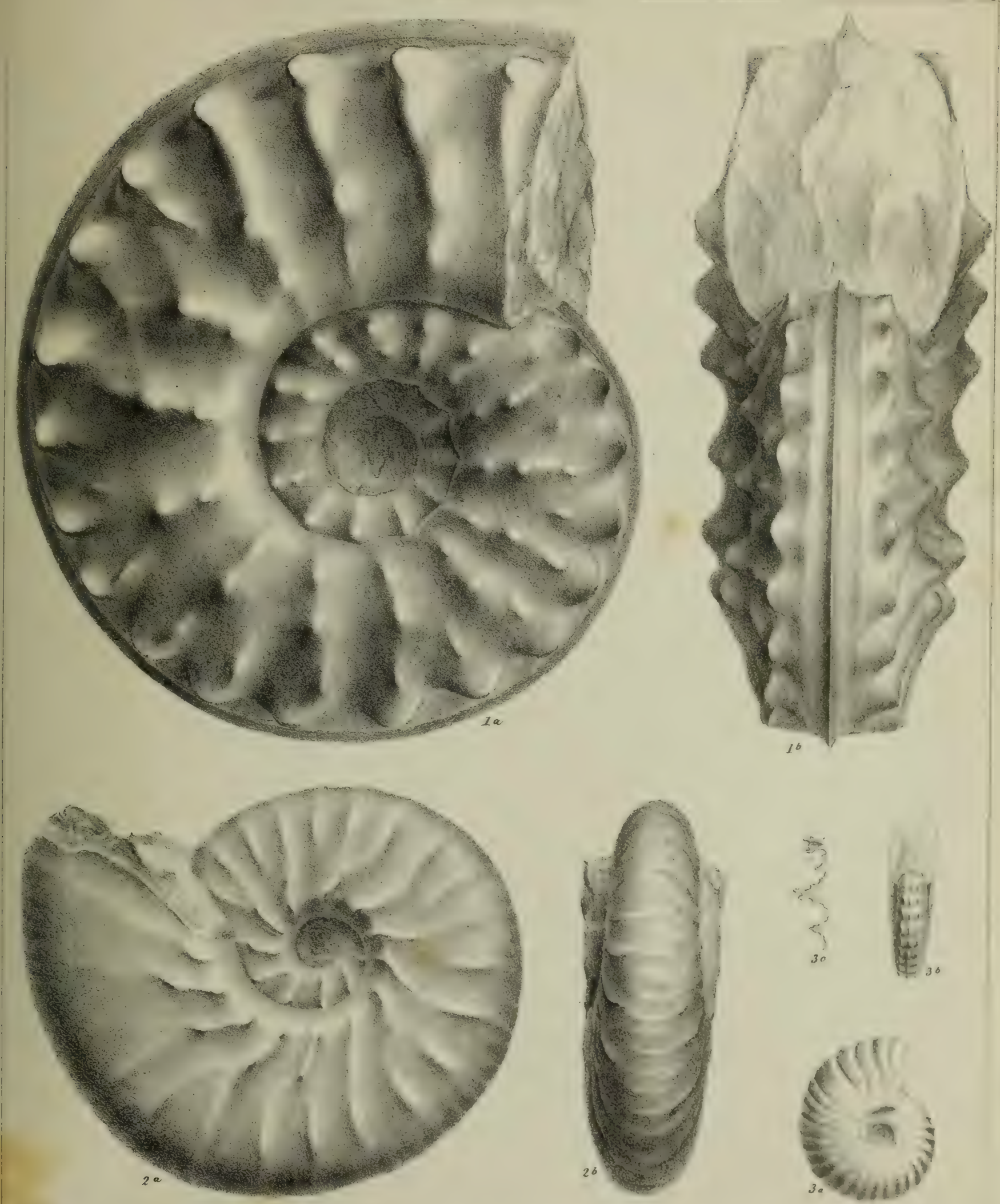

$G$ West, luch
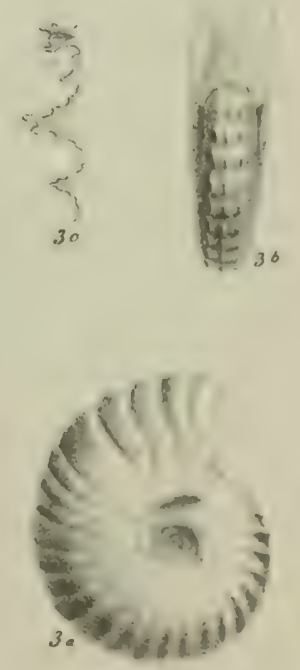




\section{PLATE II.}

Fig.

1. The brachial aponeurosis and spiral arms of Terebratula flavescens, showing the central part of the nervous system, with the brachial and beginning of the pallial nerves. Magnified 6 diameters.

2. The peduncle and a large proportion of the soft parts of Terebratula flavescens. showing the principal ramifications of the pallial nerves or the dorso-pallial fold of the mantle. Magnified 12 diameters,

3. Some of the soft parts of Lingula anatina, exposed by the removal of the valve and pallial lobe, answering to the ventral ones in Terebratula, and of the digestive organs, chiefly to show the trunks of the visceral and muscular nerves. Magnified 4 diameters. 
$P \%$ X.

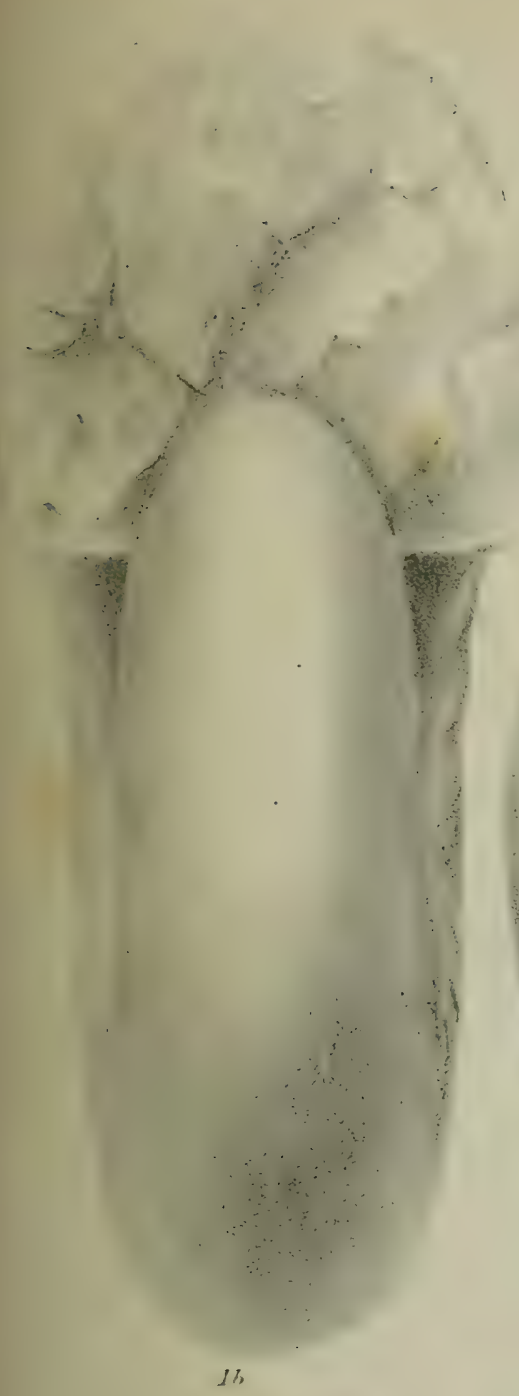

की 1 की

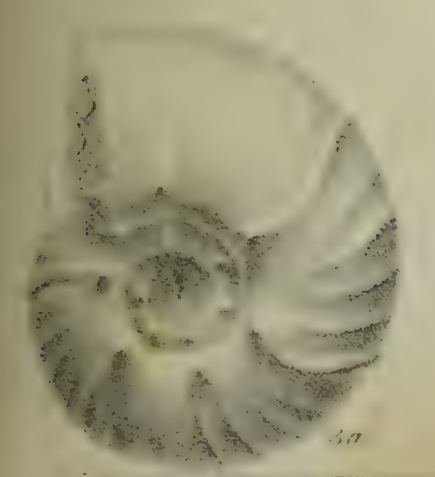

if West lich.
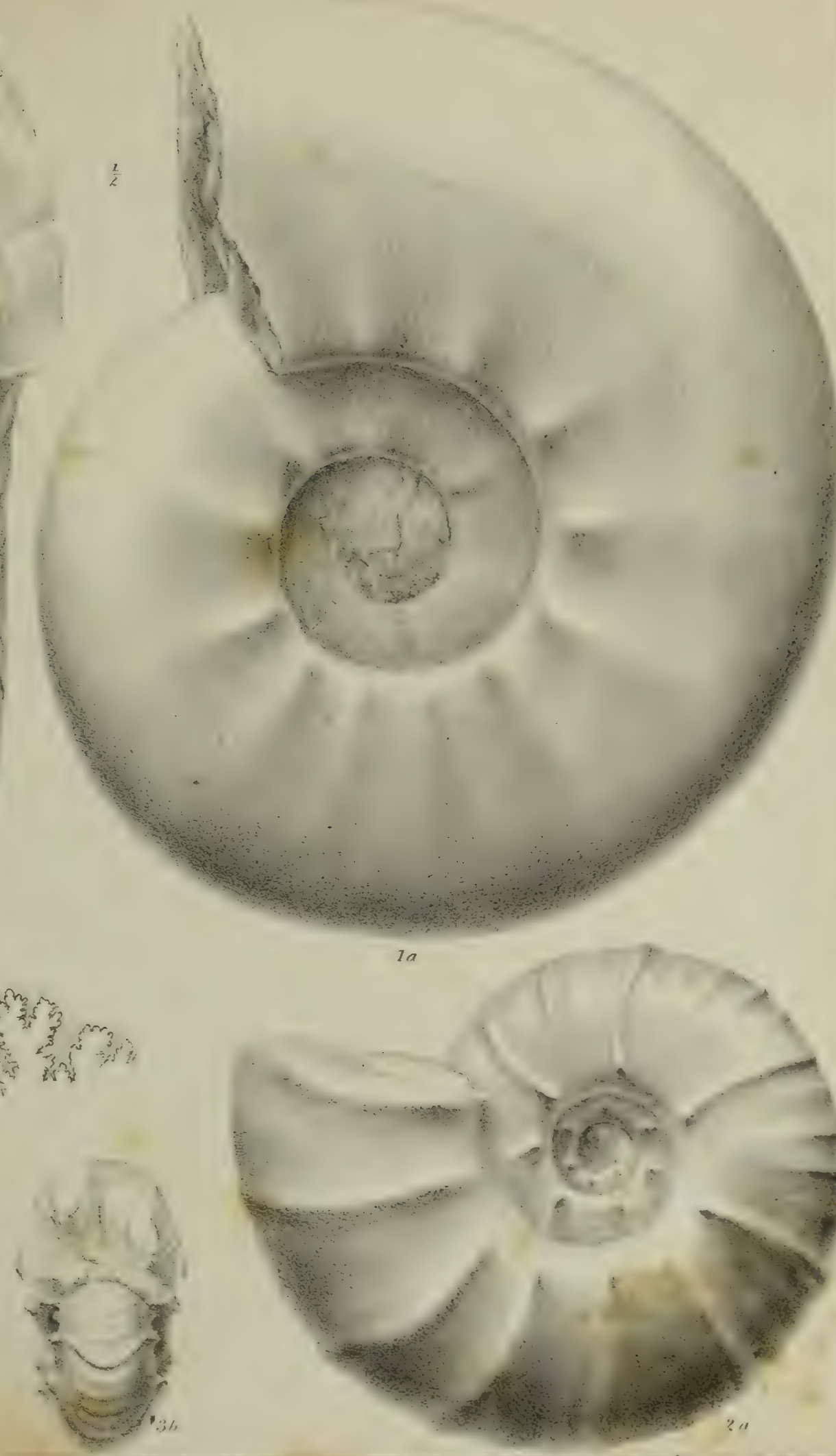


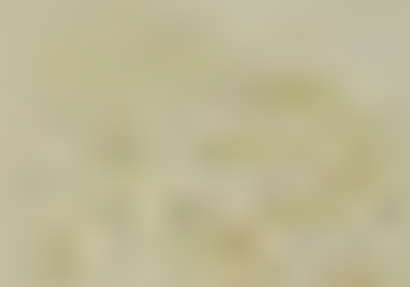

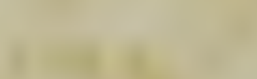

$$
\text { 12nen }
$$

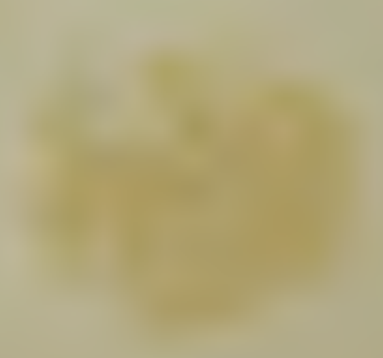





\section{PLATE XI.}

Fig.

$1 a$ and $b$. Ammonites Woollgari; from the Grey Chalk near Lewes; the original specimen in Dr. Mantell's collection, figured in his work, and in the 'Mineral Conchology,' and now in the British Museum. The portions marked $\mathrm{R}$ are restored by the artist.

$2 a$ and $b$. Ammonites Woollgari ; a young specimen from the Middle Chalk near Lewes; in the collection of Henry Catt, Esq., of Brighton.

$3 a, b$, and $c$. Ammonites GriffithiI ; internal cast from the Hard Chalk of the County of Derry; fig. $3 a$ has been completed in the inner whorls from another specimen, and fig. $3 c$ drawn from a third specimen, all in the collection of the Museum of Practical Geology, in London. 


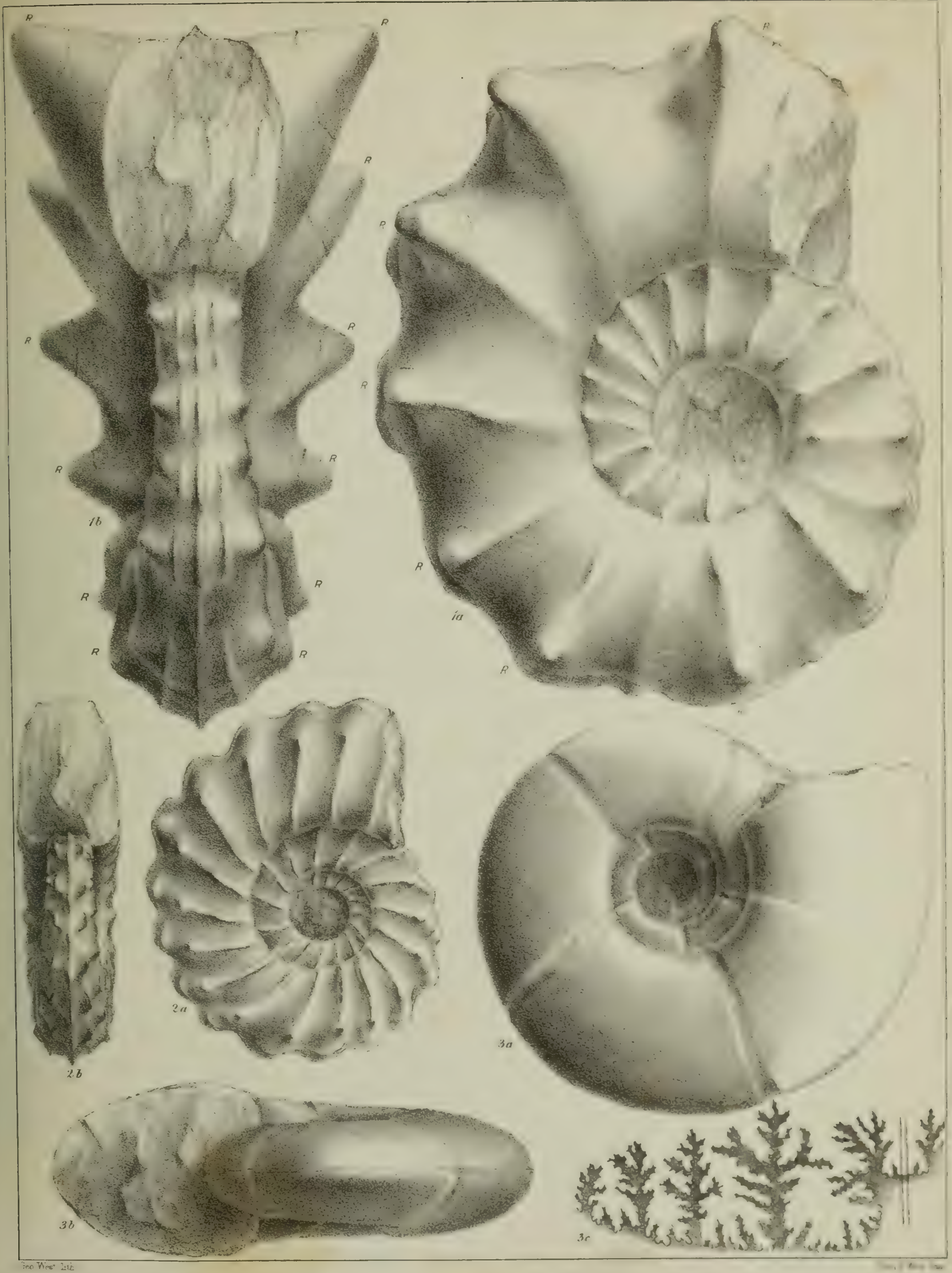






\section{PLATE XII.}

Fig.

$1 a$ and $b$. Ammonites Austeni ; reduced to one third its natural dianieter; from the Grey Chalk of Guildford; in the British Museum.

2. Amyonites Austeni; a young specimen, reduced to one half its diameter; from the Grey Chalk of Sussex; in the collection of Henry Catt, Esq.

3. Ammonites planulatus; from the Grey Chalk near Lewes; formerly in the collection of Dr. Mantell, and now in the British Museum; it is the original specimen figured in the 'Mineral Conchology ;' the parts marked $\mathrm{R}$ are restored by the artist.

$4 a, b$, and $c$. Ammonites Pianulatus; an internal cast from the Upper Green Sand near Cambridge; in the collection of Mr. L. Barrett. 

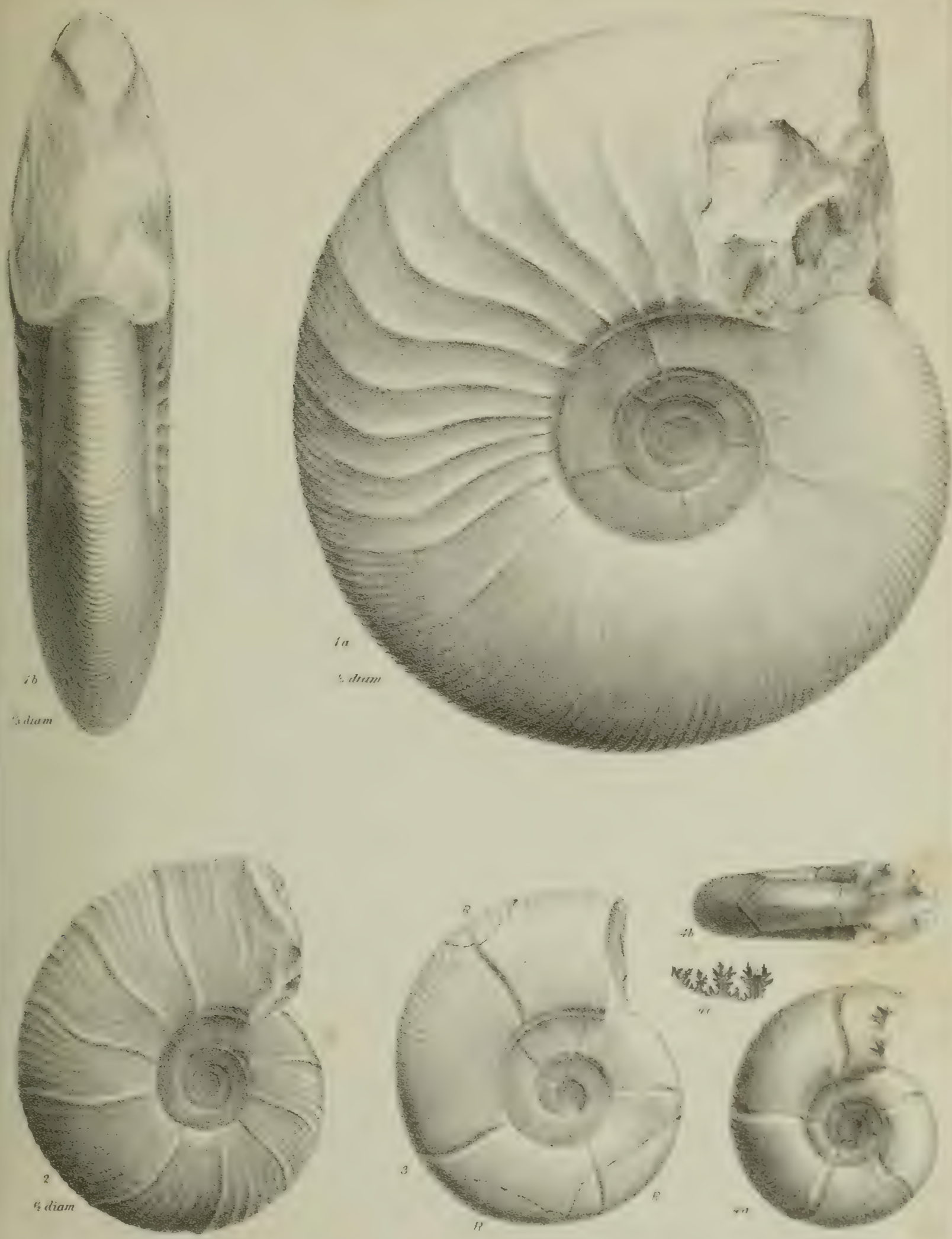




\section{PLATE XIII.}

Fig.

$1 a$ and $b$. Amsonites catinus; reduced to one half its diameter; from the Grey Chalk near Devizes; in the collection of William Cunnington, Esq., of that town.

2 and $3 a, b, c$. Ammonites Portlocki ; from the Hard Chalk of Tamlaght, in the County of Derry; in the Museum of Practical Geology, London. Pseudaspidoceras

$4 a, b$, and $c$. Ammonites evomphalus; from the base of the Lower Chalk at Man of War Cove, Dorsetshire; in the collection of E. H. Bunbury, Esq. 


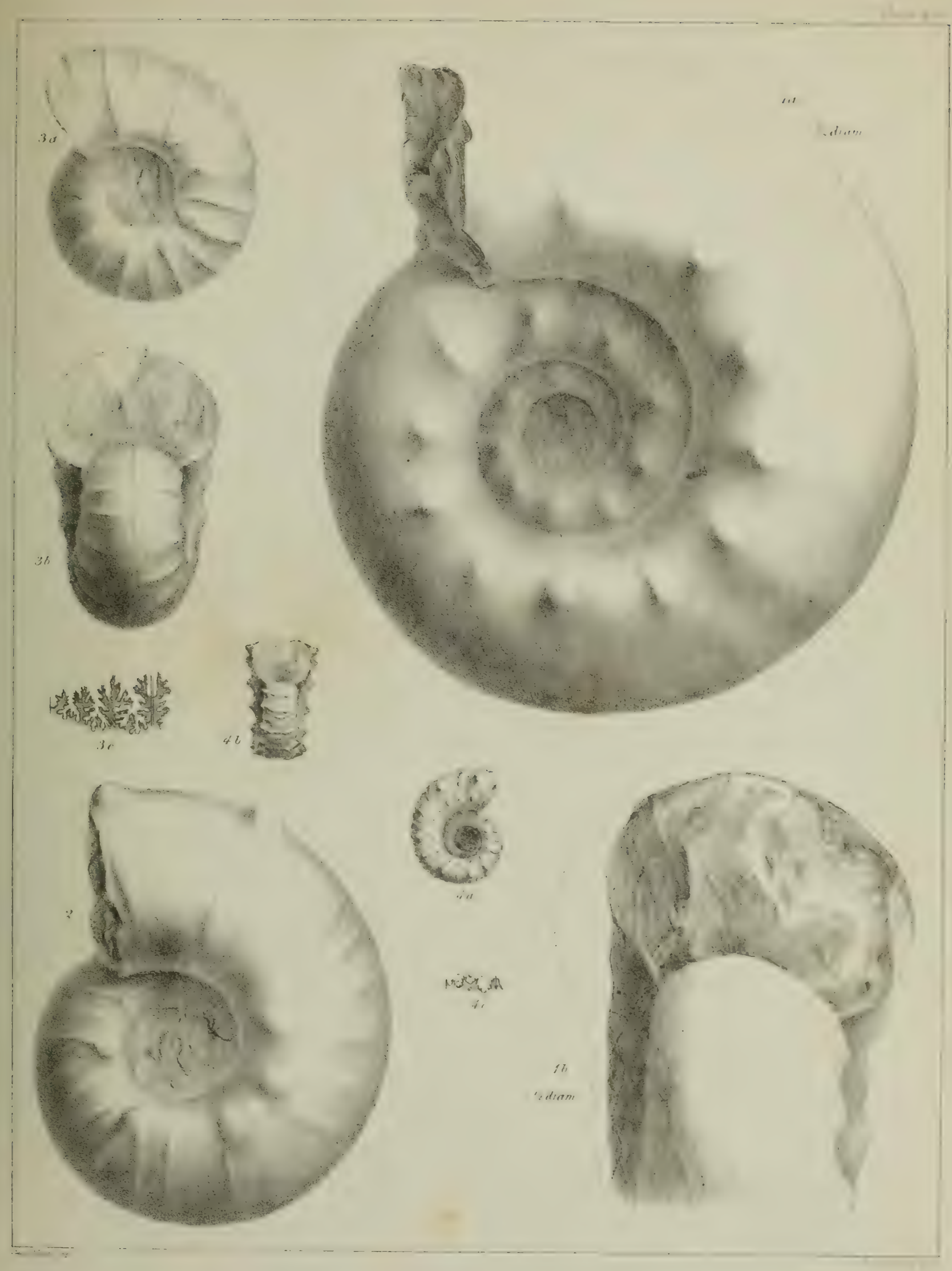






\section{PLATE XIV.}

Fig. Sharpeiceras

la and $b$. Ammonites Laticlavius; from the Grey Chalk of Bonchurch, in the Isle of Wight; in my possession.

$2 a, b$, and $c$. Ammonives Oldhami ; from the Hard Chalk of Dungivan, in the County of Derry; in the Museum of Practical Geology, London. The surface of the original was waterworn, and has been a good deal restored in the drawing.

$3 a$ and $b$. Ammonites Lepronem ; from the Grey Chalk of Ventnor, in the Isle of Wight; in my possession. 

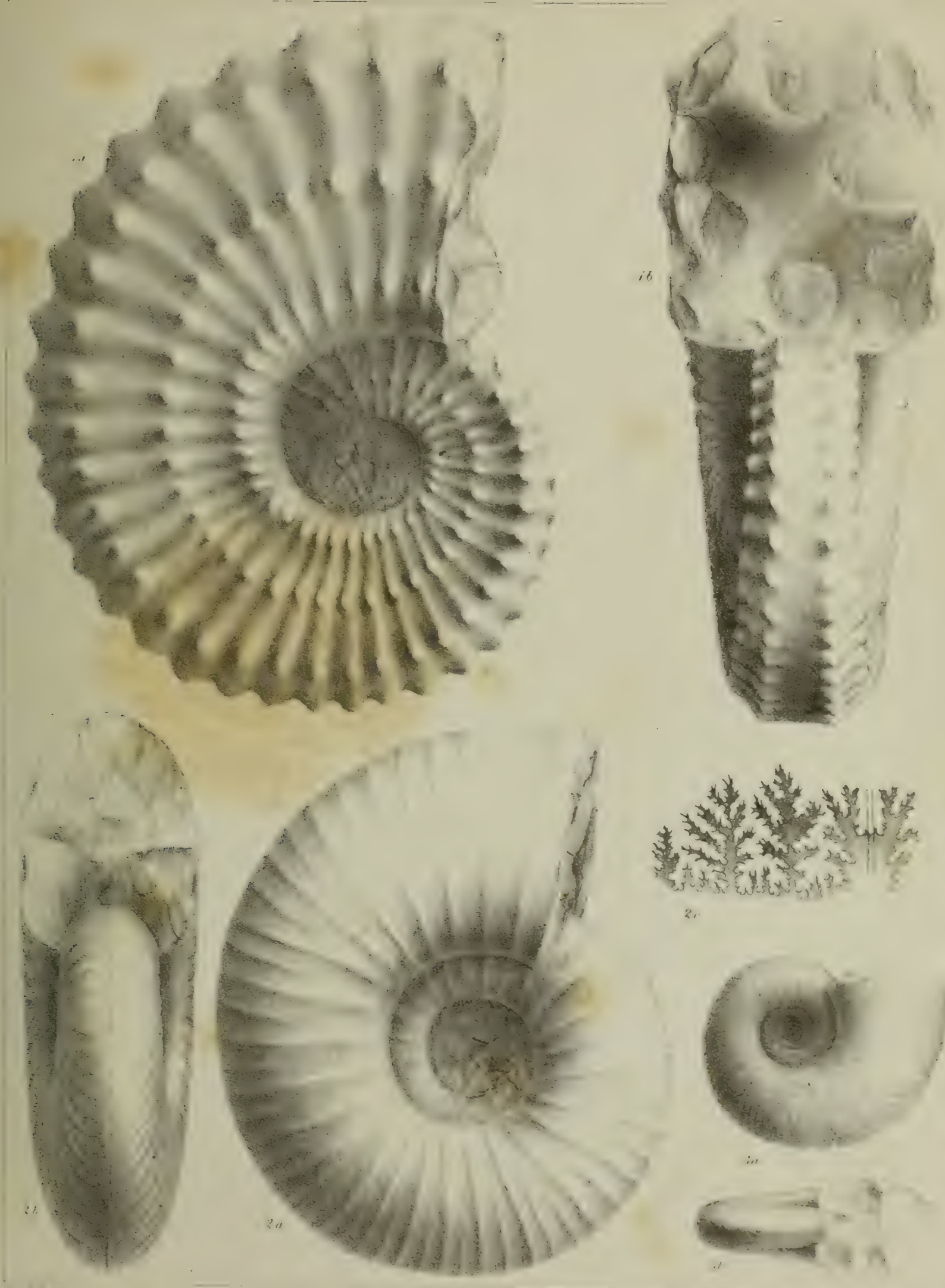

2.
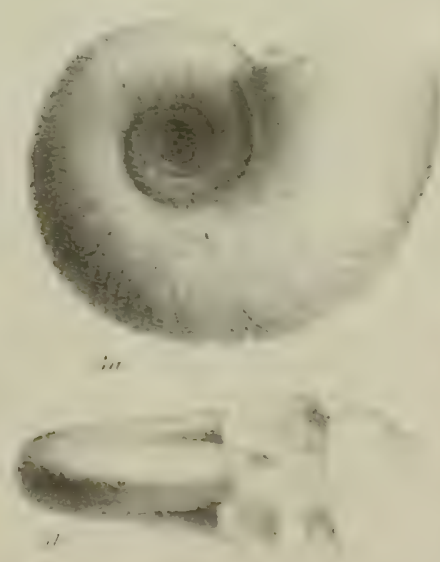




\section{PLATE XV.}

Fig. Acanthoceres

$1 a, b, c$, and $d$. Ammonites Sussexiensis; a specimen given me by Dr. Mantell, from the Grey Chalk near Lewes; reduced to two thirds its natural diameter.

$2 a, b$, and $c$. Ammonites Cunningtoni; from a specimen belonging to T. A. Falkner, Esq., of Manningford, reduced to two thirds its natural diameter; from the Grey Chalk of Upton Scudamore, near Warminster. 


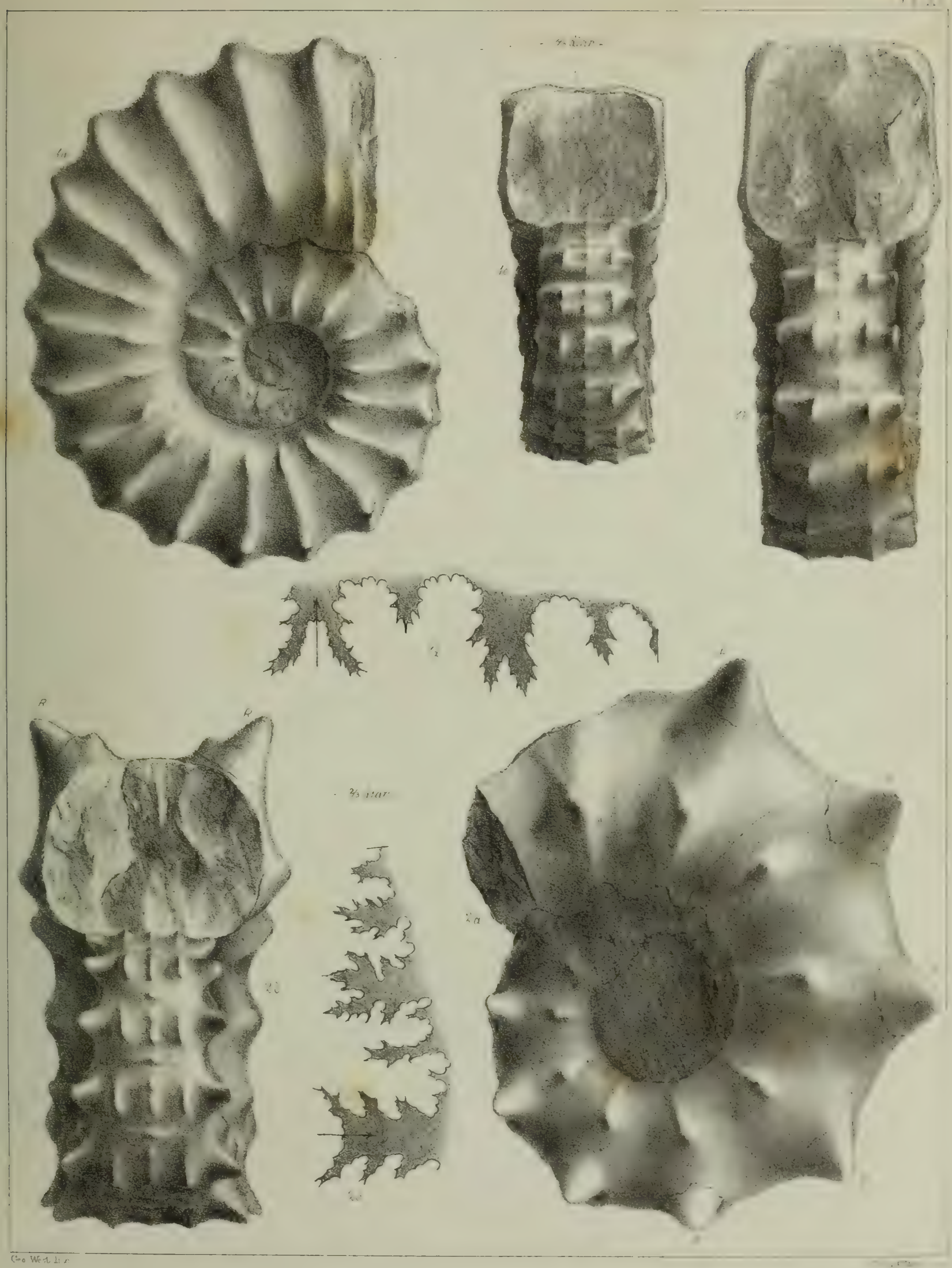






\section{PLATE XVI.}

Fig.

$1 a, b$, and $c$. Ammonites Rhoromagensis; from the Grey Chalk of Bonchurch, in the

Isle of Wight; reduced to two thirds its natural diameter; in my possession.

$1 a$ and $1 b$. Side and front views of the complete specimen.

1c. Inner whorl of the same specimen.

$2 a$ and $b$. Ammonites Rhotomagensis; from the Grey Chalk of Bonchurch; of the natural size; in my possession.

$3 \alpha$ and $b$. Ammonites Rhotomagensis; a very young specimen, from the Grey Chalk of Bonchurch; in my possession.

4. Ammonites Rhotomagensis; outline of the septum of a specimen from the Grey Chalk near Lewes. 


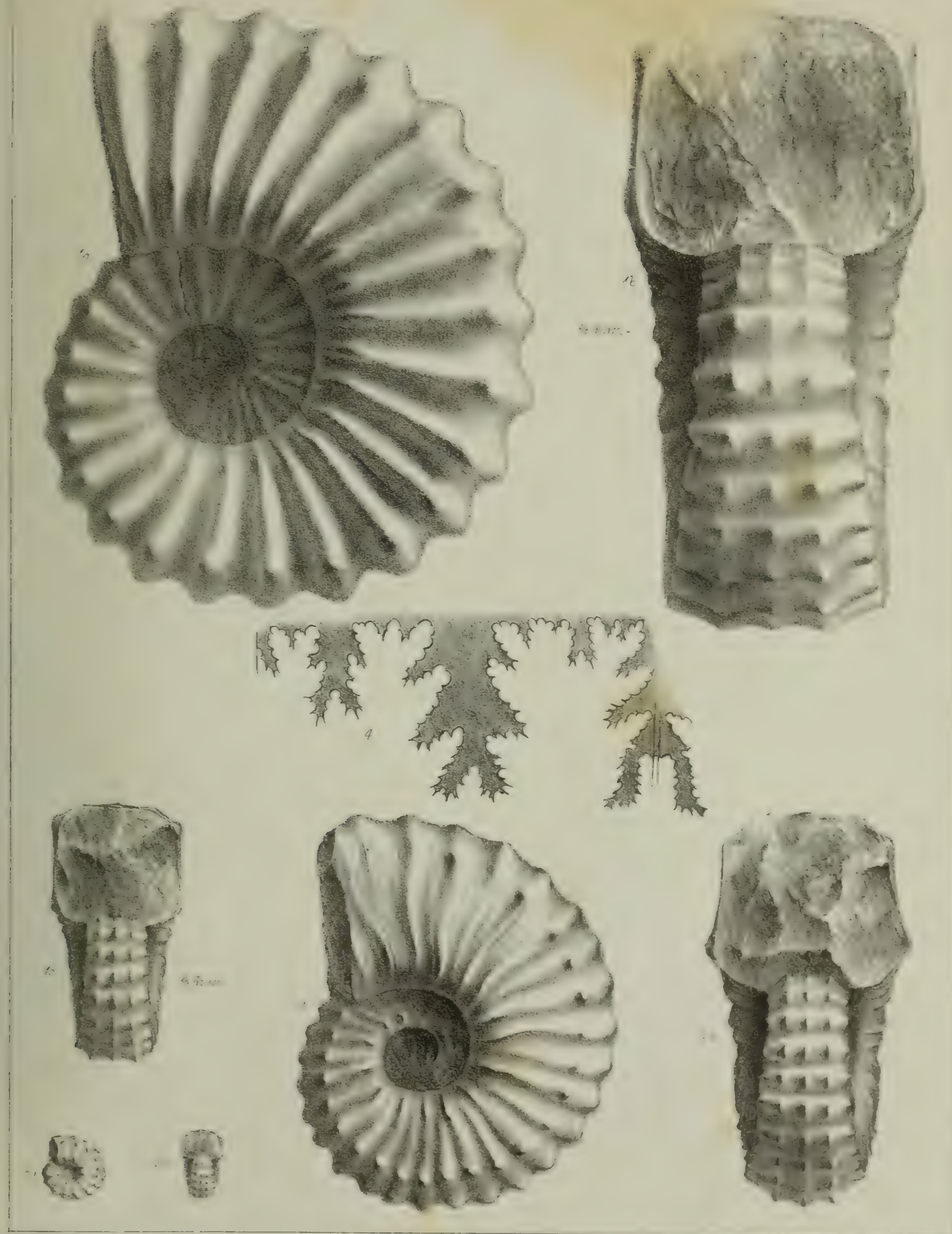






\section{PLATE X VII.}

Fig.

la and b. Ammonites Cenomanensis; from the Grey Chalk of Dover; reduced to two thirds its natural diameter; in the collection of J. S. Bowerbank, Esq., p. 37 .

$1 a$, side view.

16 , front view.

2. Ammonites hippocastanum; from the Lower Chalk of Man of War Cove, Dorsetshire; in the collection of E. H. Bunbury, Esq., p. 37.

3a and $b$. Ammonites hippocastanum, young; from the Lower Chalk of Chardstock; in the collection of E. H. Bunbury, Esq, p. 37.

$3 a$, side view.

36 , front view.

$4 a, b$, and $c$. Ammonites hippocastanum; a fragment, from the Lower Chalk of Chardstock; in the collection of E. H. Bunbury, Esq., p. 37.

$4 a$, back view.

$4 b$, side view.

$4 c$, outline of a septum.

$5 a$ and $b$. Ammonites Goupilianus; from the Lower Chalk of Sussex; in the British Museum, from the collection of Dr. Mantell, p. 38.

6. Ammonites Goupilianus ; outline of a septum, copied from Pl. xciv of M. D'Orbigny's ' 'Paléont. Franç. Terr. Crét.,' p. 38.

$7 a$ and $b$. Ammonites Velled ; from the Upper Chalk near Norwich; in the collection of F. G. Bayfield, Esq., of Norwich, p. 39.

$7 a$, side view. N.B. The umbilicus is represented too large, the artist having been deceived by the breaking away of the soft chalk.

$7 b$, front view. 


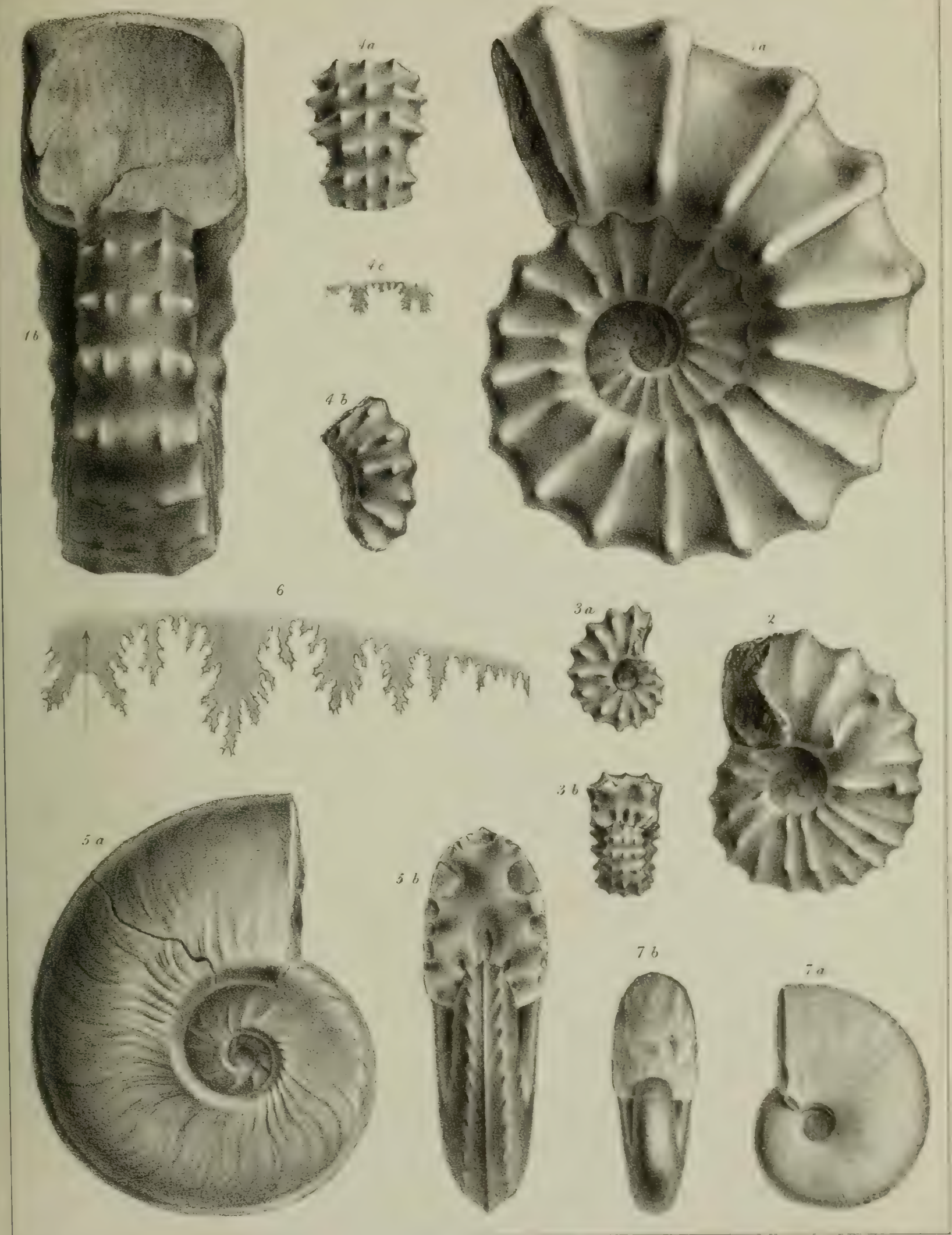






\section{PLATE XVIII.}

Fig. $\operatorname{sincos}:$

1. Ammonites Naviculanis; from the Grey Chalk of White Nore, Dorsetshire; in the collection of E. H. Bunbury, Esq., p. 39.

2. Ammonites navicularis; from the Grey Chalk near Lewes; in the collection of Henry Catt, Esq., p. 39.

$3 a$ and $b$. Ammonites Navicularis; from the Lower Chalk of Chardstock; in the collection of John Morris, Esq., p. 39.

$3 a$, front view.

$3 b$, side view.

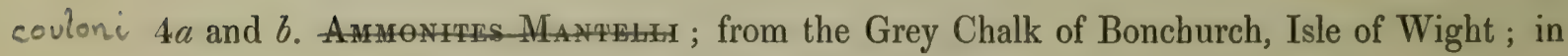
the collection of S. Saxby, jun., Esq., p. 40.

$4 a$, side view.

$4 b$, front view.

' $5 a, b$, and $c$. Ammonites Navicularis; from the Lower Chalk of Chardstock; in the collection of John Morris, Esq., p. 39.

$5 a$, side view.

$5 b$, front view.

$5 c$, front view of the inner whorl of the same specimen.

Manteniceras

$6 a$ and $b$. AmMONIHES MAnTElLI; from the Chloritic Marl of the Isle of Wight; in the collection of John Morris, Esq., p. 40.

$6 a$, side view.

$6 b$, front view.

$7 a, b$, and $c$. Ammontres Manteliz; from the Chloritic Marl of Bonchurch, Isle of Wight; in the collection of S. Saxby, jun., Esq., p. 40.

$7 a$, side view.

76 , front view.

$7 c$, outline of septum.

8. Ammonites navicularis; outline of the septum of the specimen fig. 1 , above. 


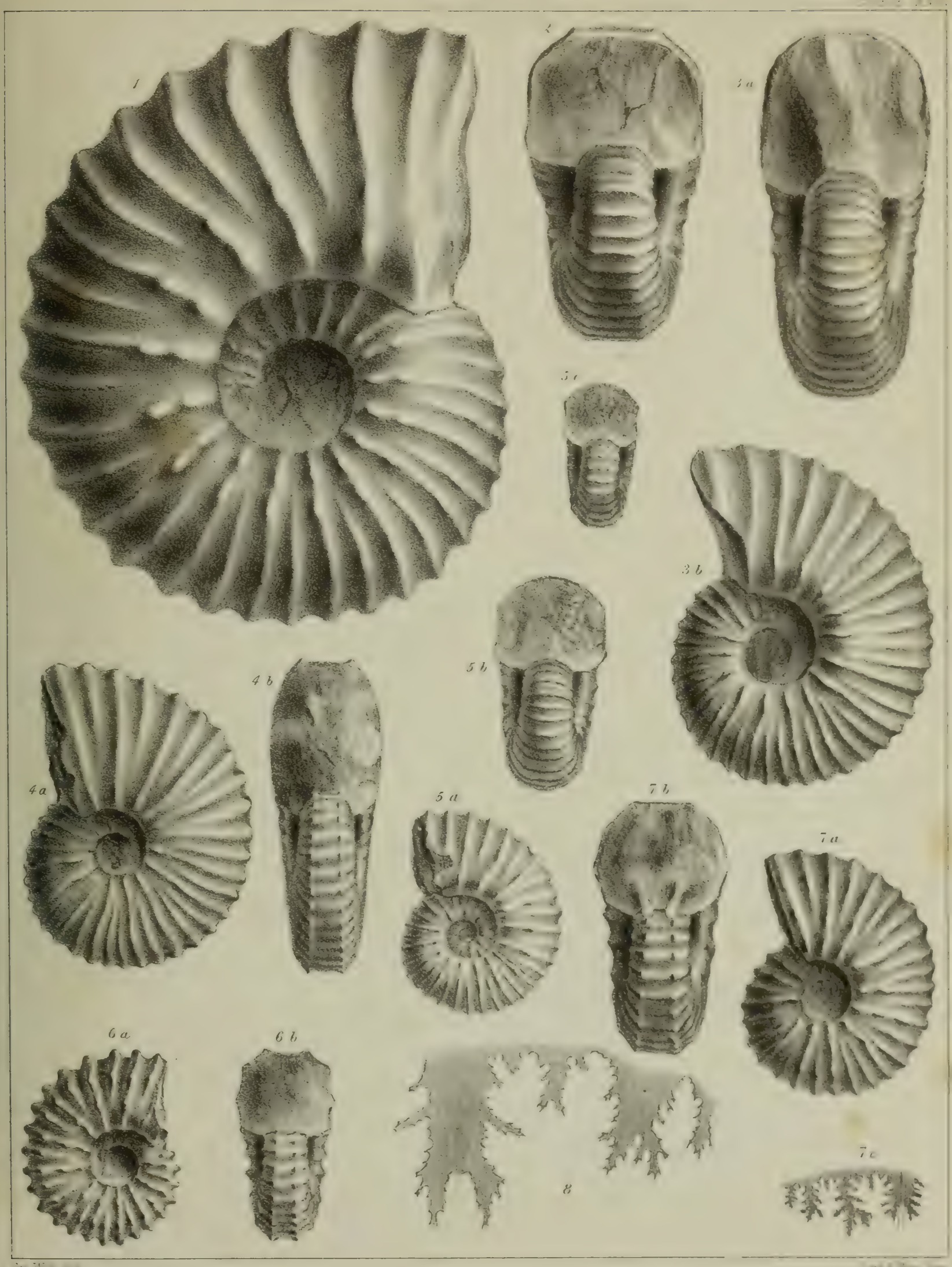






\section{PLATE XIX.}

Fig.

$1 a, b$, and $c$. Ammonites CoupeI ; var., from the Grey Chalk of Ventnor, Isle of Wight; in my possession, p. 23.

$1 a$, side view.

$1 b$, back view.

$1 c$, section of a whorl.

$2 a, b$, and $c$. Ammonites Renauxianus; a young shell, from the Grey Chalk of Ventnor, Isle of Wight; in my possession, p. 41.

$2 a$, side view.

$2 b$, back view.

$3 c$, front view of inner whorl of the same specimen.

$3 a$ and 6. Ammonites octo-sulcatus; from the Grey Chalk of Ventnor, Isle of Wight; in my possession, p. 42 .

$3 a$, side view.

$3 b$, front view.

$4 a$ and $b$. Ammonites Icenicus; from the Upper Chalk, near Norwich; in the collection of Mr. King of Norwich, p. 43.

$4 a$, side view, showing the outline of a septum.

$4 b$, front view.

$5 a$ and 6. Ammonites Deverianus; from the Grey Chalk of Sussex; in the British Museum, from the collection of F. Dixon, Esq., p. 43.

$5 a$, side view.

$5 b$, front view.

6. Ammonites Vellede; from the Grey Chalk of Ventnor, Isle of Wight; in my possession, p. 39.

6 , outline of a septum. 

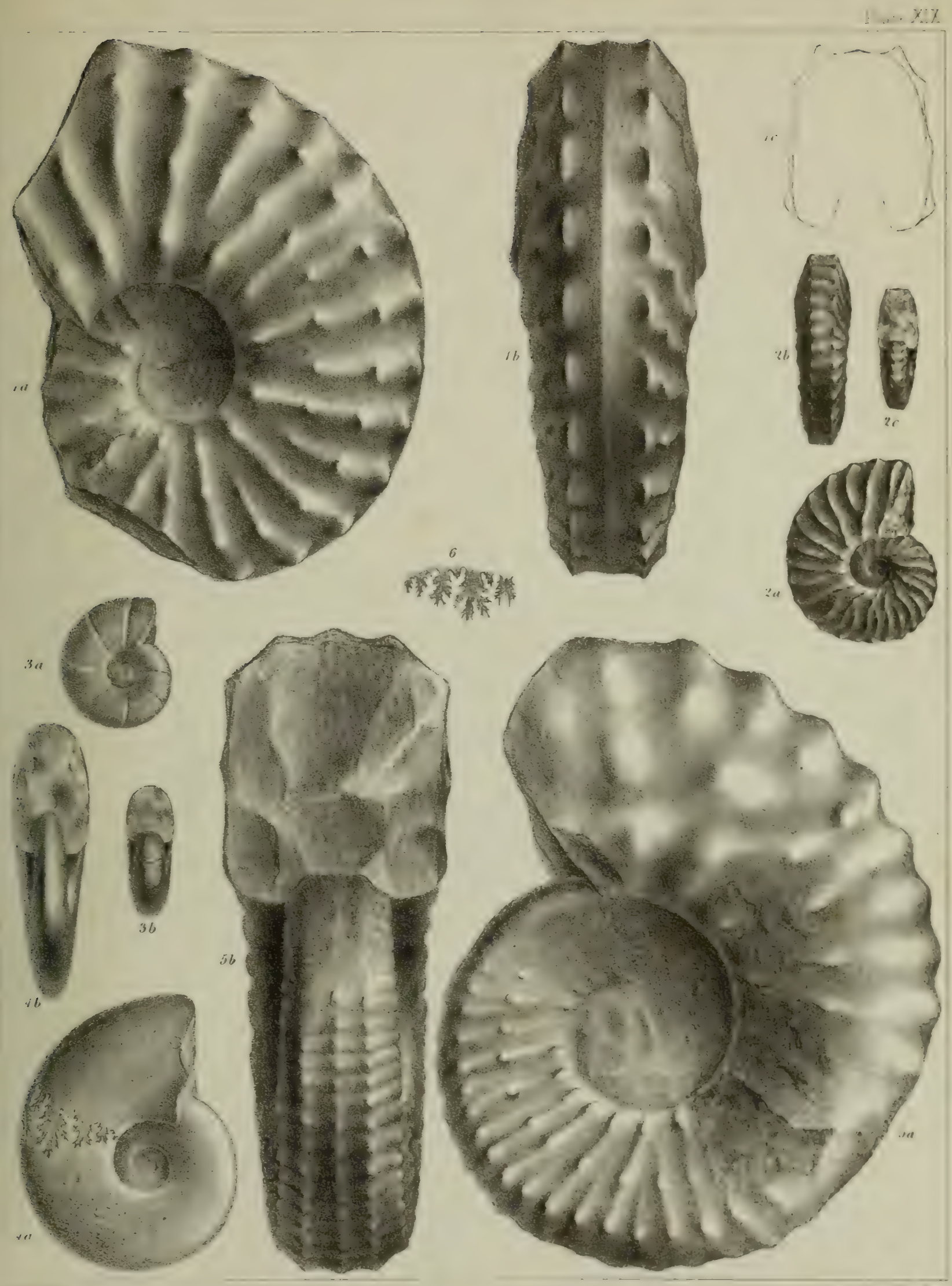




\section{- PLATE XX}

Fig. Metasiga 7. . . :

$1 a, b, c$. Ammonites Rosticus ; from the Lower Chalk, near Lyme Regis ; in the Museum of Practical Geology; reduced to two thirds its natural diameter, p. 44. The surface of the inner part has decayed away.

$1 a$, side view.

$1 b$, back view.

$1 c$, section of the outer whorl.

Acompsoceras
$2 a, b$, and $c$. Ammonites Renevieni; from the Grey Chalk, near Blackdown, Isle of $2 a$, side view .

$2 b$, front view.

$2 c$, outline of a septum.

$3 a$ and $b$. Ammonites Saxbir ; from the Grey Chalk of Ventnor, Isle of Wight; in my possession, p. 45

$3 a$, side view.

$3 b$, front view.

$4 a$ and $b$. Ammonites Vectensis; from the Chloritic Marl of Ventnor, Isle of Wight; in my possession, p. 45 .

$4 a$, side view.

$4 b$, front view. 


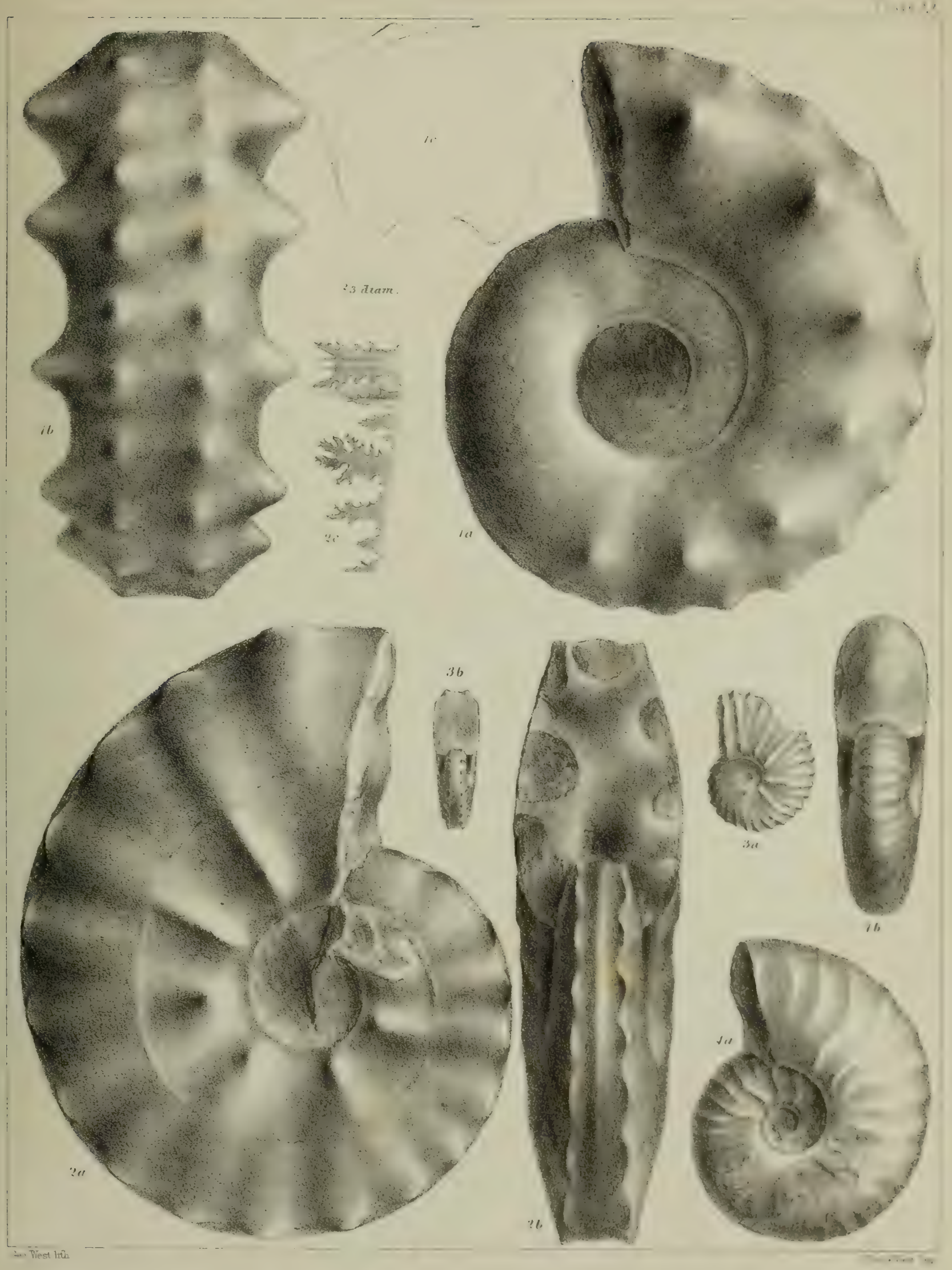






\section{PLA' E XXI.}

rig. Hariscerces

la, b, c. Ammonites Lewesiensis; from the Grey Chalk, near Dover; in the collection of S. J. Mackie, Esq., of Folkstone, p. 46.

$1 a$, side view.

16 , front view.

$1 c$, outline of a septum.

2. Ammonites Leptophylus ; outline of a septum of the specimen, Plate XXII, fig. I.

$3 a, b, c$. Ammonites Wiestil; from the Chalk with silicious grains, Chardstock, Somersetshire; in the collection of J. Wiest, Esq., p. 47.

$3 a$, side view.

36 , back view.

$3 c$, section of a whorl. 


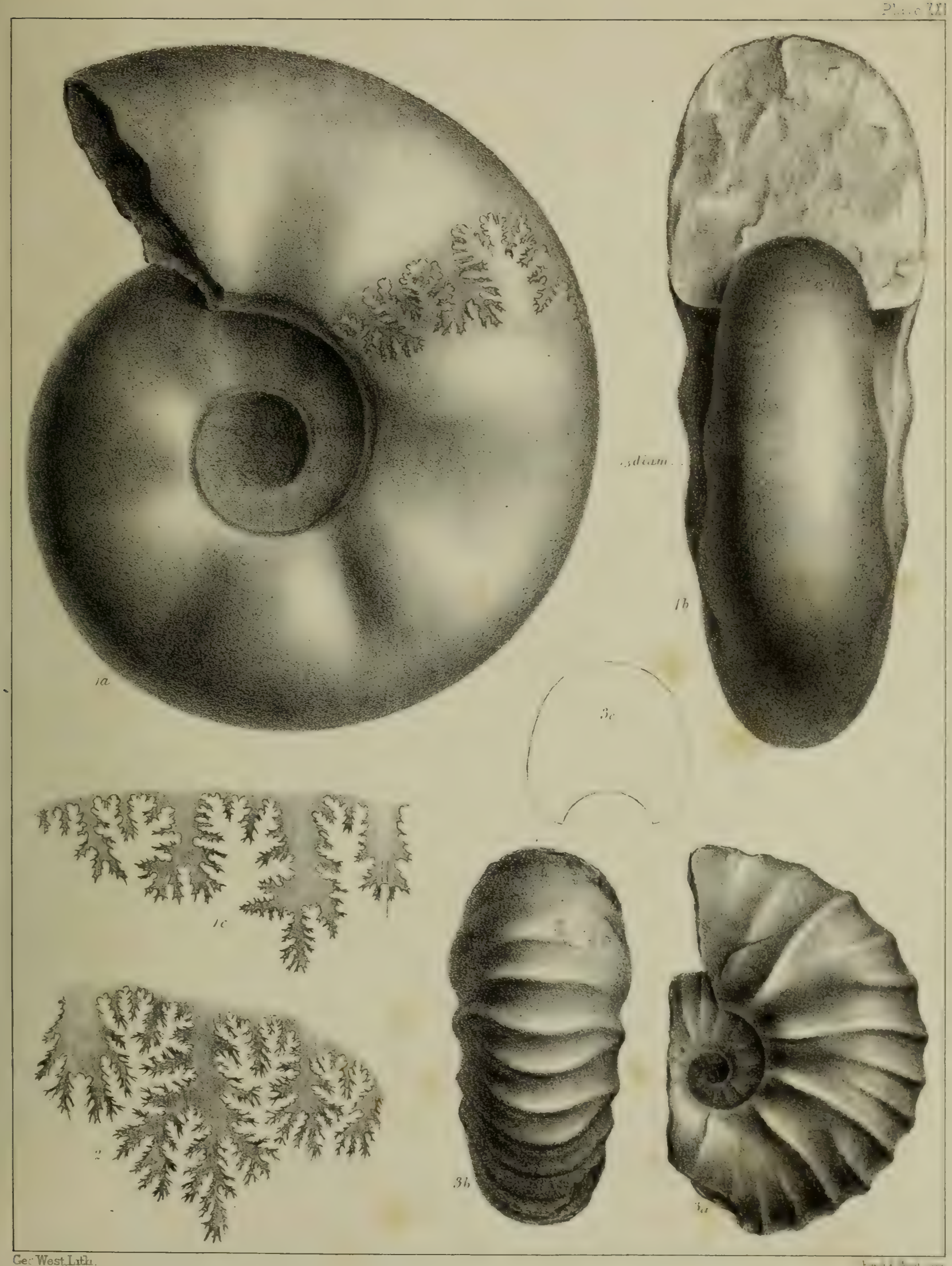






\section{PLATE XXII.}

Fig.

1a, b. Amonites leptophyluus; from the Upper Chalk of Greenhithe, Kent; in the collection of L. Barrett, Esq., reduced to two fifths its natural diameter, p. 48.

$1 a$, side view.

16 , front view.

Para nach dis -.:

2 $a, b, c$. Aimonites Gollevillensis; from the hard Chalk of Damlaght, in the county of Derry, Ireland; in the Museum of Practical Geology; reduced to three fourths its natural diameter, p. 48.

$2 a$, side view.

$2 b$, front view.

$2 c$, outline of a septum. 


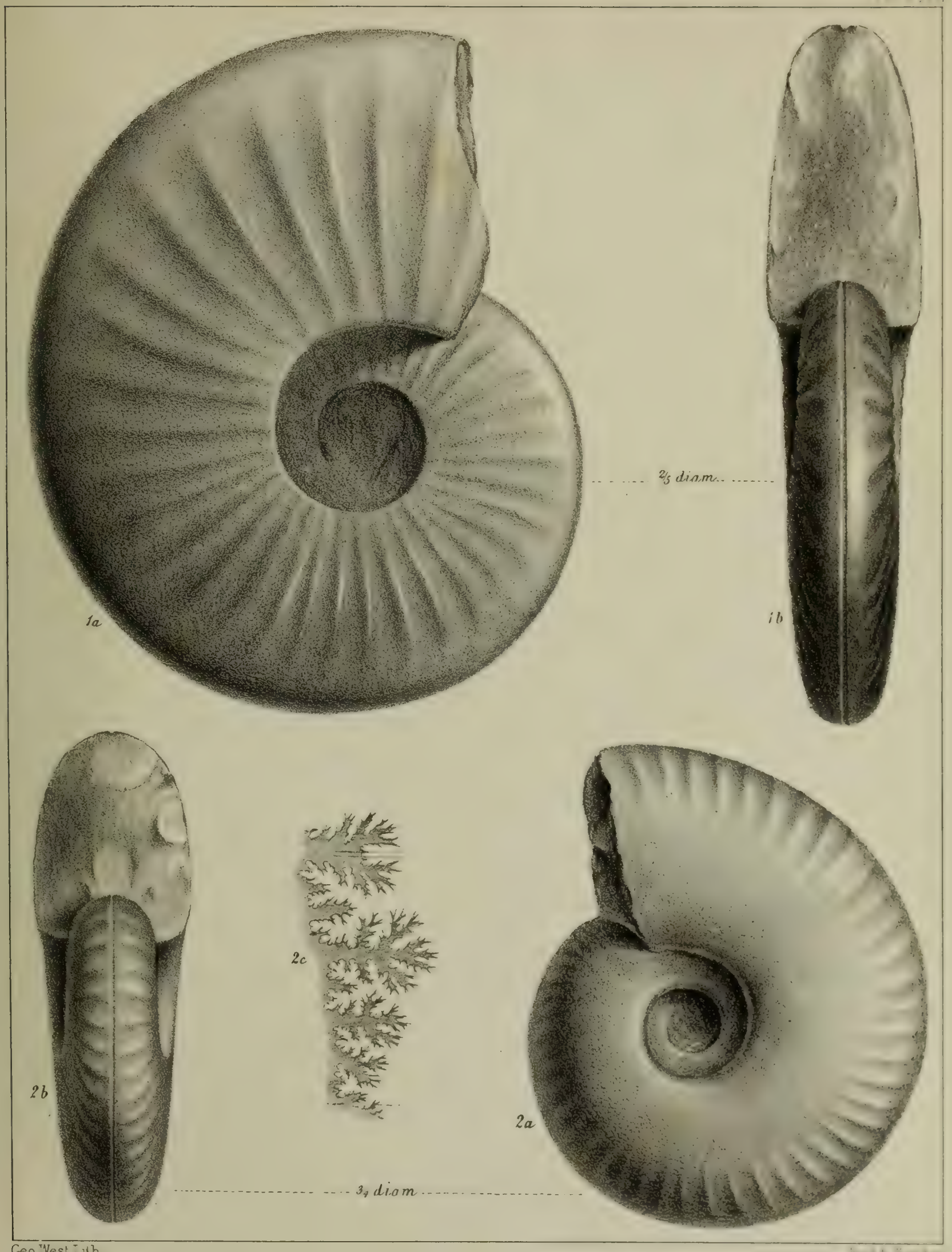

Geo West, Lilh

4,16 




\section{PLA'L XXIII.}

Fis.

l $a, b, c$. Ammonites curvatus; from the Grey Chalk of Veutnor, Isle of Wight ; in my la, side view. possession, p. 49.

16, front view.

$1 c$, outline of a septum.

¿. Ammonites falcatus; outline of the septum of a specimen from the Chloritic Marl of Ventnor, Isle of Wight; in my possession, p. 21.

$3 a, b$, c. Ammonites Salteri; from the Chalk with siliceous grains, Chardstock, $3 a$, side view.

Somersetshire; in the collection of J. Wiest, Esq., p. 50.

36 , front view.

$3 c$, outline of a septum.

$4 a, b, c$. Ammonites Ramsayanus; from the Chalk with siliceous grains, Chardstock, Somersetshire; in the collection of J. Wiest, Esq., p. 5l.

$4 a$, view of the left side.

$4 b$, view of the right side.

$4 c$, front view.

ja, b. Ammonites Sal'teri ; from the Chalk with siliceous grains, Chardstock, Somerset$5 a$, side view. shire; in the collection of J. Wiest, Esq., p. 50.

56 , front view.

$6 a, b, c$. Ammonites Feraudianus ; from the Grey Chalk of Ventnor, Isle of Wight ; in $6 a$, side view. iny possession, p. 52 .

$6 b$, front view.

$6 c$, back view.

7a, b. Ammonites Bravaisiands; copied from Plate XCI, figs. 3 and 4, of D’Orbigny's 'Paléontologie Française, Terrains Crétacés.' p. 52.

8. Ammonites Bravaisianus; from the Middle Chalk of Dover; in the collection of of S. J. Mackie, Esq.: the specimen has been worn, and the tubercles are nearly all rubbed off, p. 52.

9. Ammonites Bravaisianus; from the Middle Chalk of Dover; in the collection of J. W. Flower : restored by the artist from a broken specimen, p. ว2.

$10 a, b, c$. Ammonites WILtonensis; from the Grey Chalk, near Devizes, Wiltshire; in the collection of W. Cunnington, Esq., of Devizes, p. 53.

$10 a$, side view.

106 , front view.

$10 c$, outline of a septum.

$11 a, b, c, d, e$. Аммомires Jukesi ; from the hard Chalk of the county of Londonderry; in the Museum of Practical Geology, p. 53.

$11 a$, side view of a fragment, with part of three whorls.

$11 b$, side view of the two inner whorls of $11 a$.

$11 c$, back view of 116 .

$11 d$, section of the whorls restored.

$11 e$, part of the outline of a septum. 


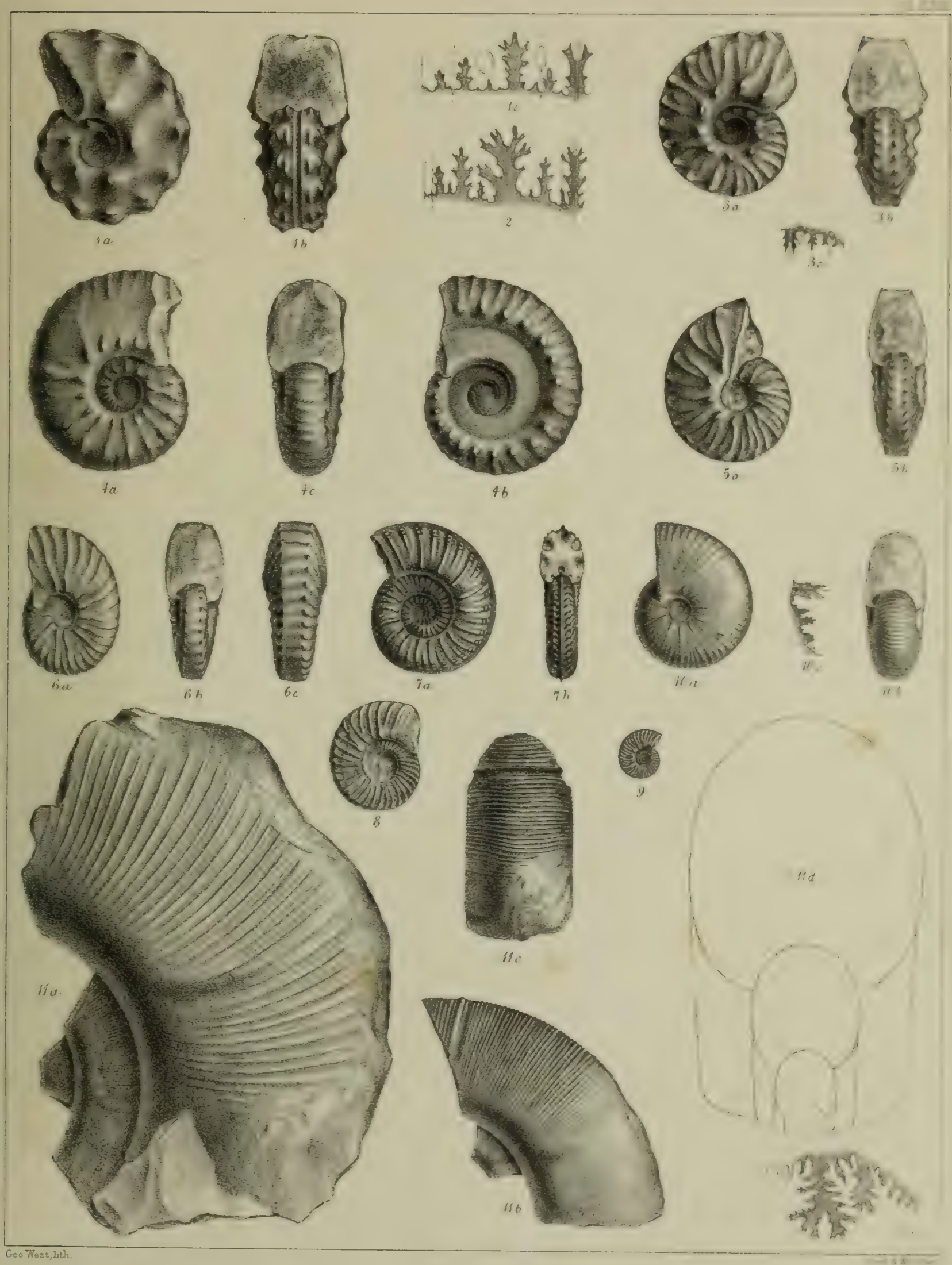






\section{PLATE XXIV.}

Fig.

la, $b$. Aptychus Leptophyllus; from the Upper Chalk of Brighton; in Mr. Sharpe's collection (Geol. Soc.), p. 55.

$l a$, concave (internal) surface.

$1 b$, smooth, convex surface.

2, 3, 4. Aptrchus Portlockir; from the Upper Chalk of Norwich; 2 and 3 in the collection of Mr. Bayfield; 4 in the British Museum, p. 56.

5. Aptychus Gollevillensis; Upper Chalk, Norwich; in the collection of Mr. Bayfield, p. 56.

6. Aptychus Portlockit? p. 56.

7. Aptrchos Icenicus; Upper Chalk, Norwick; Mr. Bayfield, p. 57.

$8 a, b$, and 9. Aptychus Rugosus; Upper Chalk, Norwich, p. 57.

$8 a$, external, sculptured surface of a pair of valves; in the collection of Mr.

Bayfield, p. 57.

$8 b$, internal surface, showing lines of growth.

9, external surface of a large valve, in the collection of Mr. John King, of Norwich, p. 57.

10a, b. Aptrchus Peramplus; Upper Chalk, Norwich; Mr. Bayfield, p. 58.

$10 a$. internal, striated surface.

$10 b$, external surface of a fragment.

11. Outline of the aperture of Ammonites Icenicus.

12.

13.

14

15 .

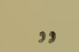

,

"

",
,

,

,

s)
A. PortLockir.

A. LEPTOPHYLLUS.

A. PERAMplus.

A. Golleviluensis. 


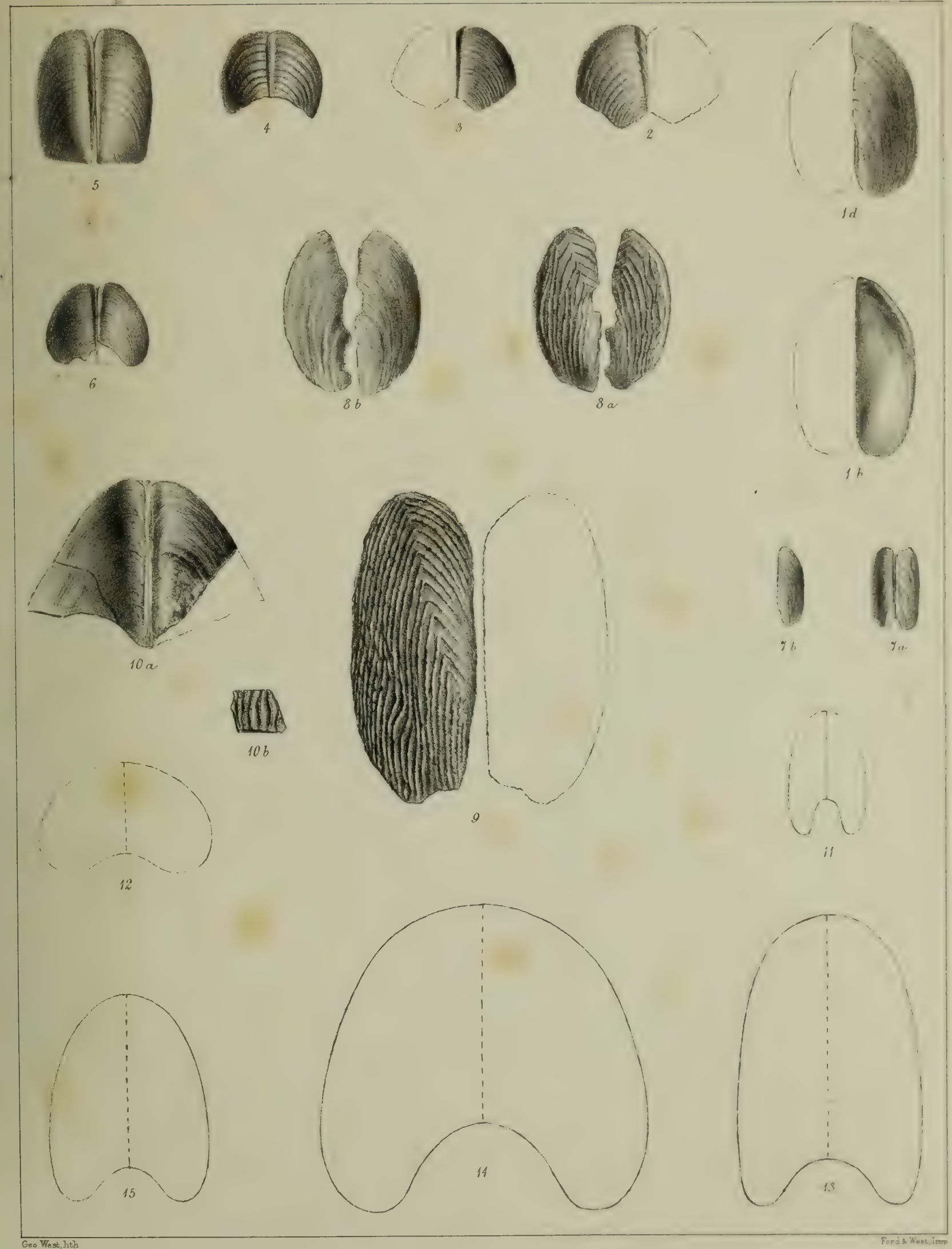




\section{PLATE XXV.}

Fig.

1. Torrilites tubercolatus; from the Grey Chalk of Ringmer, Sussex; in the British Museum, from the collection of Dr. Mantell, p. 61.

2. Turrilites tobercolatus, showing the produced mouth; from the Grey Chalk, near Lewes; in the British Museum, from the collection of Dr. Mantell, p. 61.

3. 'I'URRilites tuberculatus; a fragment, showing the position of the lobes of a septum on the outer side of a whorl; from the Grey Chalk of Ventnor, Isle of Wight, in my possession, p. 61 .

4. Turrilites tuberculatus; a young specimen, from the Grey Chalk of Ventnor, Isle of Wight; in the collection of S. Saxby, jun., Esq., p. 61.

5. Turrilites Mantelli ; from the Grey Chalk, near Lewes; part of the outline of a septum is shown on the upper whorl; in the British Museum, from the collection of Dr. Mantell, p. 63.

6a, b. Turrilites Mantelli ; from the Grey Chalk, near Lewes; an adult individual, showing the produced mouth; in the British Museum, from the collection of Dr. Mantell, p. 63.

$7 a, b$. Turrilites Gravesianus; from the Grey Chalk, near Lewes; the position of the lobes of a septum is shown on the lower whorl of fig. $7 a$; in the British Museum, from the collection of Dr. Mantell, p. 62. 









\section{PLA'TE XXVI.}

Fig.

1. Turrilitus Scheuchzeriaxus; adult, with the mouth produced; from the Grey Chalk of Ventuor, Isle of Wight; in my possession, p. 64.

2. 'T'UrRilites Schedchzerianus; a young shell, on which part of the produced mouth is preserved; from the Grey Chalk of Ventnor, Isle of Wight; in my possession; p. 64 .

3. Turrilites Scheuchzerianus? a very young shell, with the produced mouth completely formed; from the Grey Chalk of Ventnor, Isle of Wight; in my possession, p. 64.

$4,5 a, b, 6,7 a, b$, and 8. 'Turrilites Morrisin; five specimens of different ages; from the Chloritic Marl of Ventnor, Isle of Wight; in my possession, p. 65.

$5 b$, shows the base of the whorl of $5 a$.

$7 b$, is the outline of the septum of $7 a$.

9. Turrilites Bergeri ; a fragment, showing part of the outline of a septum; from the Chloritic Marl of Ventnor, Isle of Wight; in my possession, p. 65.

10. Turrilites Bergeri; a fragment, from.the Grey Chalk, near Lewes; in the British Museum, from the collection of Dr. Mantell, p. 65.

11. Turrilites BerGeri; fragment of a young shell; from the Chalk with siliceous grains, Chardstock, Somersetshire; in the collection of J. Morris, Esq., p. 65.

$12, a, b$. Turrilites, species undetermined; the last whorl of an adult shell, with the mouth produced; from the Grey Chalk of Lewes; in the British Museum, from the collection of Dr. Mantell.

13a, b. Turrilites Bechei; from the Chalk with siliceous grains, near Lyme Regis; part of the outline of a septum is seen on the second whorl; presented to the British Museum by the late Sir H. T. de la Beche, p. 66.

14. Turrilites Gravesianus; outline of part of a septum.

15. Turrilites tuberculatus; outline of part of a septum.

16. 'I'urrilites tuberculatus; outline of part of a septum; from the Chloritic Marl of Bonchurch, Isle of Wight; in the collection of S. Saxby, jun., Esq., p. 61. 


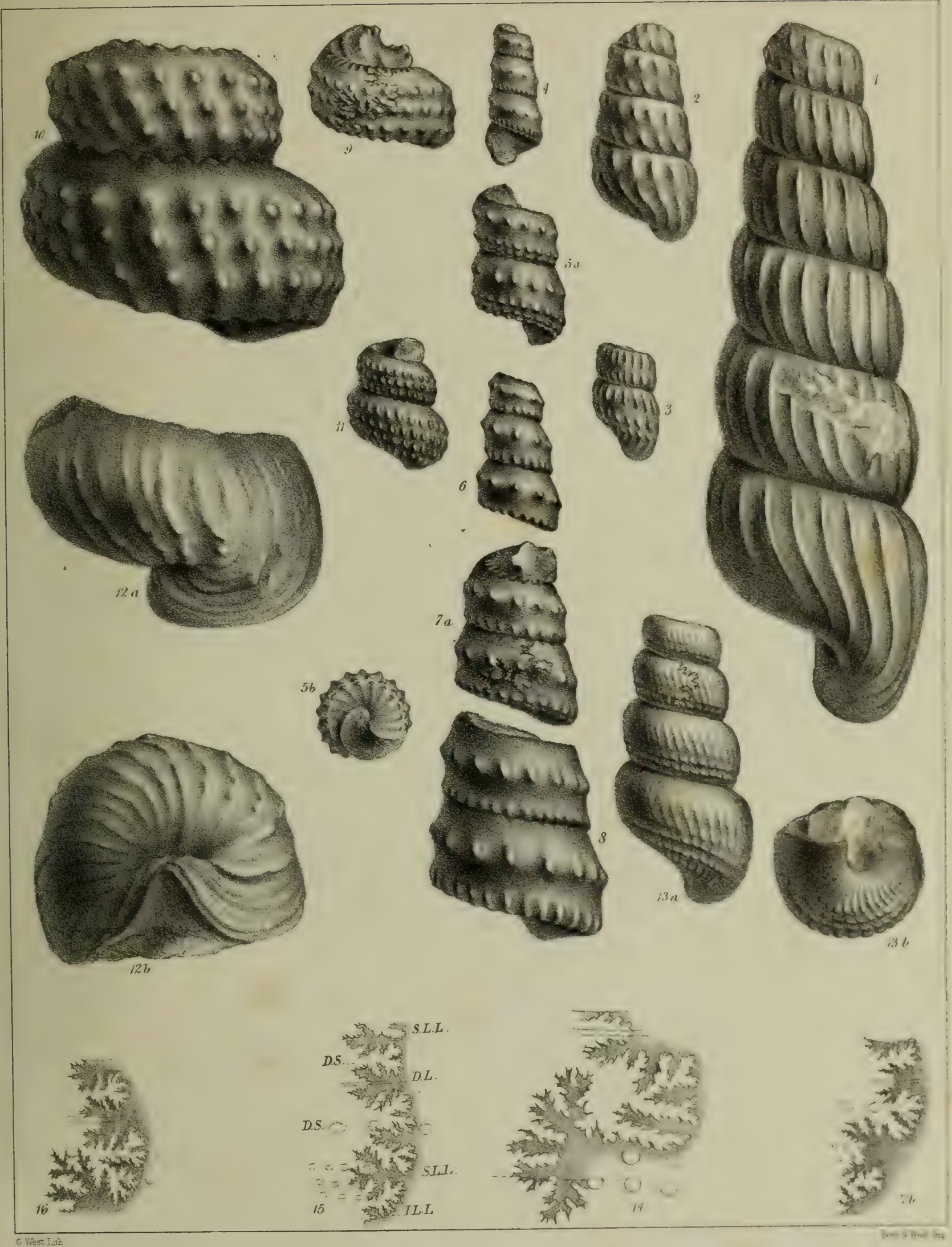






\section{PLATE XXVII.}

Fig.

1. Turrilites costatus; young, from the Grey Chalk of Ventnor, Isle of Wight; in my possession, p. 66 .

$2 a, b$. Turrilites costatus; adult, with the mouth completely formed; from the Grey Chalk of Ventnor, Isle of Wight; in my possession, p. 66.

$2 a$, side view.

$2 b$, view of the base, with the perfect mouth.

3 and 4. Turrilites costatus; two small specimens which have already formed the produced mouth; from the Grey Chalk of Ventnor, Isle of Wight; in ny possession, p. 66 .

5. Turrilites costatus; young, from the Grey Chalk of Ventnor, Isle of Wight; in my possession, p. 66 .

6 and 7. Turrilites birrons? D' Orb.; from the Lower Chalk, Ventnor, p. 67.

8. Turrilites WiestiI ; from the Grey Chalk of Ventnor, Isle of Wight; in my possession, p. 67.

$9 a, b$. Turrilites Wiestir; young, from the Chalk with siliceous grains, Chardstock, Somersetshire; in the collection of Mr. John Morris, p. 67.

$9 a$, side view.

$9 b$, base of a whorl.

10. Torrilites Bergeri? var.; from the Chloritic Marl of Bonchurch, Isle of Wight. (Mr. Saxby.)

11. Turrilites Puzosianus, D'Orb. var.; from the Chloritic Marl of Bonchurch, p. 65.

12. Turrilites costatus, var.; from the Lower Chalk of Ventnor, Isle of Wight.

13. Turrilites tuberculatus, var.; from the Lower Chalk of Ventnor.

These two figures $(12,13)$ are doubtfully referred to the above species, and may hereafter prove to be distinct: the specimens are only fragments, and in an imperfect state of preservation.

14a, $b$. Turrilites WiestiI, var.; from the Lower Chalk of Ventnor.

15. Turrilites costatus, var. T. triplicatus, J. Sow.; Lower Chalk, Sussex; from the original in the British Museum, p. 66.

16. Septum of T. costatus, p. 66 .

17. Septum of T. Wiestii, p. 67. 


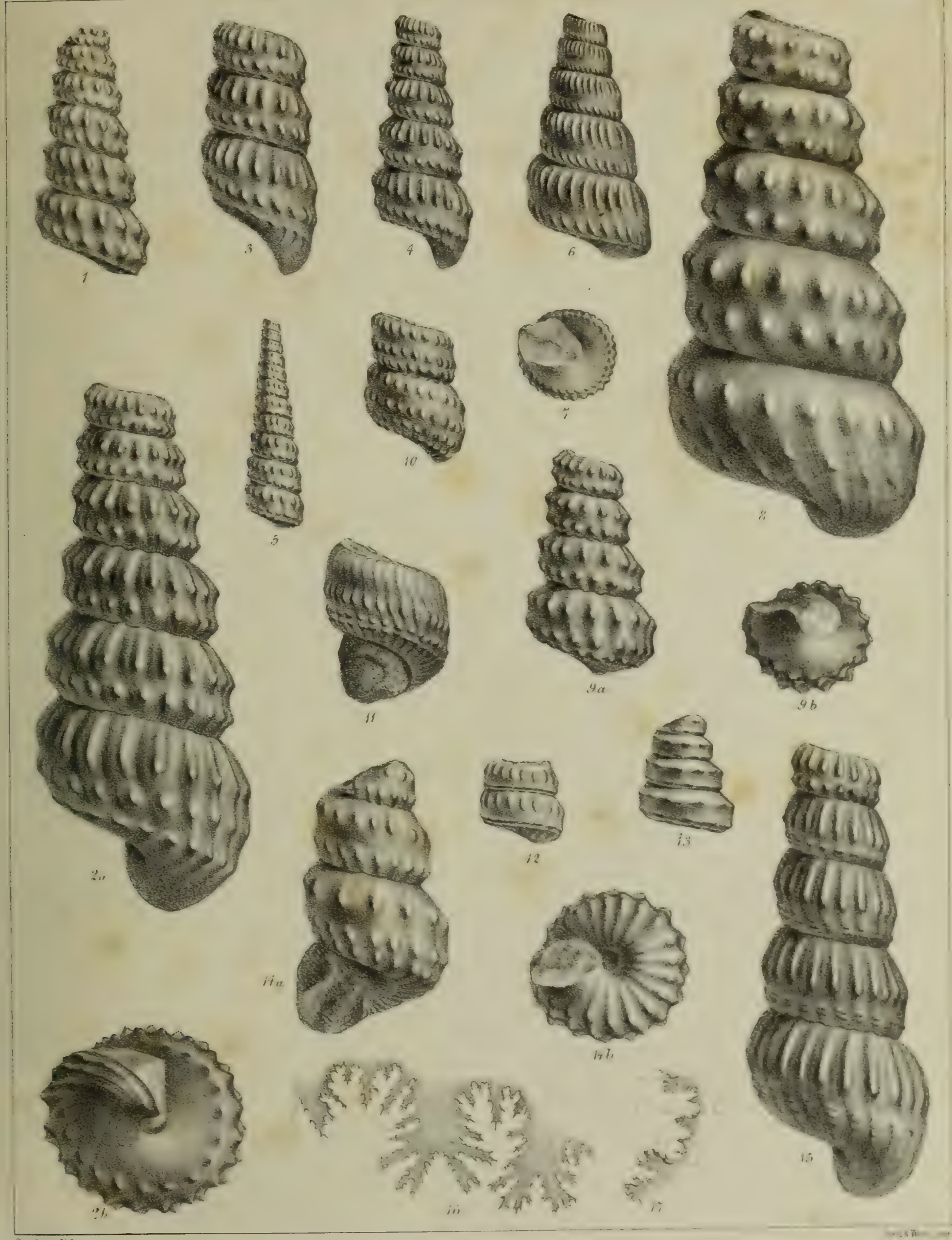









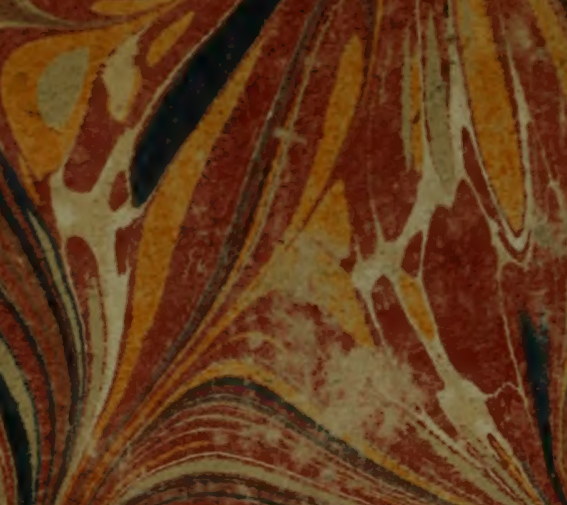

- Ir par

$=(\sqrt{ }) \sqrt{2} \sqrt{2}$

$=(\sqrt{ }) \sqrt{2} \sqrt{2}$

$=(\sqrt{ }) \sqrt{2} \sqrt{2}$

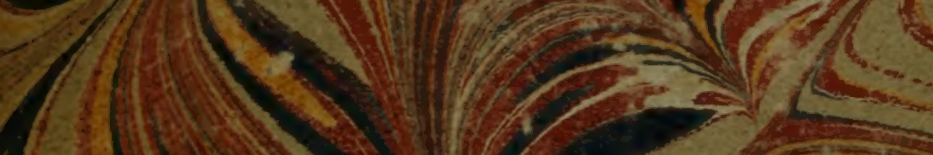

1212

(1) $x$
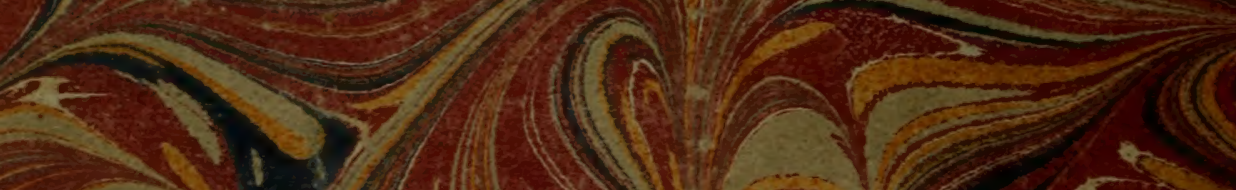

3.

HWI ( $, 2,1$

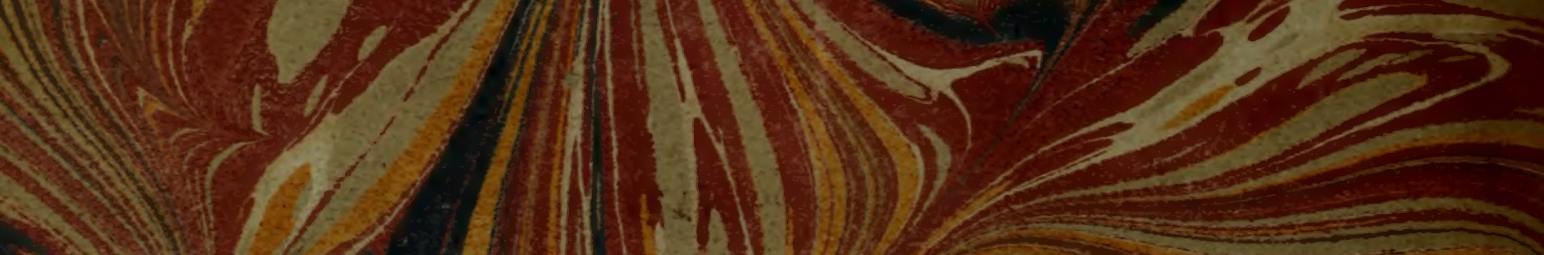
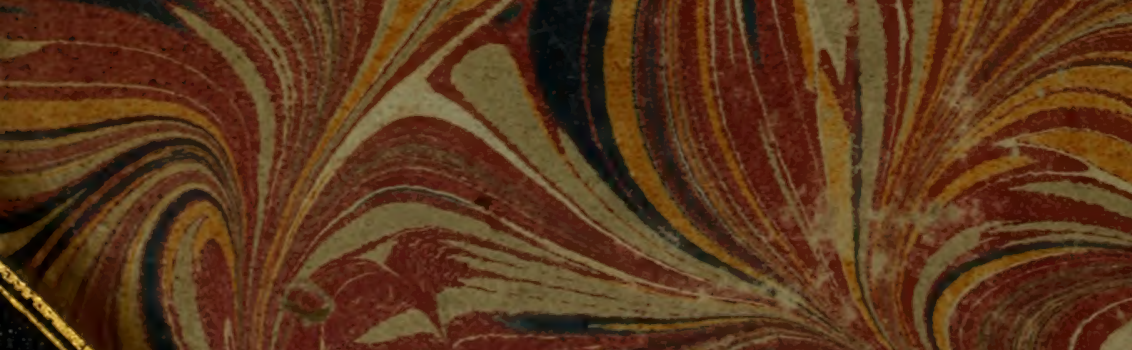